HYDROGEOLOGY AND GEOCHEMISTRY

OF THE UNSATURATED ZONE, RADIOACTIVE

WASTE MANAGEMENT COMPLEX, IDAHO

NATIONAL ENGINEERING LABORATORY, IDAHO

by C.T. Rightmire and B.D. Lewis

U.S. GEOLOGICAL SURVEY

Water-Resources Investigations Report 87-4198

Prepared in cooperation with the

U.S. DEPARTMENT OF ENERGY

Idaho Falls, Idaho

November 1987 


\author{
DEPARTMENT OF THE INTERIOR \\ DONALD PAUL HODEL, Secretary \\ U.S. GEOLOGICAL SURVEY \\ Dallas L. Peck, Director
}

For additional information write to:

Project Office

U.S. Geological Survey

P.O. Box 2230

INEL, CF-690, Room 164

Idaho Falls, ID 83403-2230
Copies of this report can be purchased from:

Books and Open-File Reports Section Western Distribution Branch

Box 25425, Federal Center, B1dg. 810 Denver, CO 80225

Telephone: (303) 234-5888 


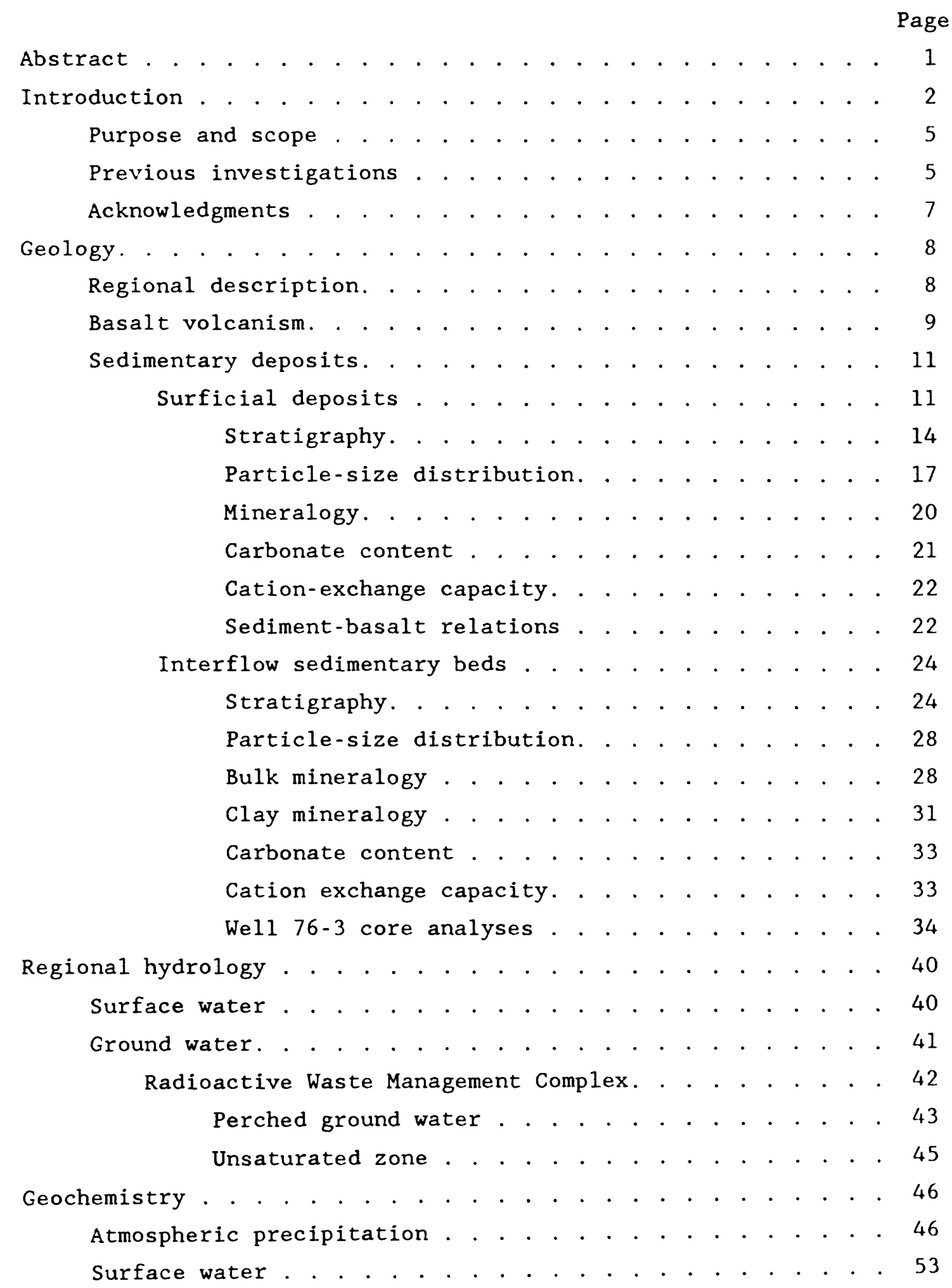


Unsaturated zone gases. . . . . . . . . . . . . . 55

Ground water. . . . . . . . . . . . . . . . . 59

Stable isotope analyses of sedimentary material . . . . . 67

Summary. . . . . . . . . . . . . . . . . . . . . . . . . . 80

Selected references. . . . . . . . . . . . . . . 84

\section{ILUUSTRATIONS}

Figure 1. Location of the Idaho National Engineering

Laboratory and eastern Snake River Plain, and

the relation of the Radioactive Waste Management

Complex and adjacent wells to the diversion areas

and the Big Lost River. . . . . . . . . . . . . . . 3

2. Location of selected Idaho National Engineering

Laboratory facilities . . . . . . . . . . . . 4

3. Location of wells and waste disposal pits and

trenches at the Radioactive Waste Management

Complex . . . . . . . . . . . . . . . . . 6

4. Thickness of surficial sedimentary deposits at

the Radioactive Waste Management Complex. . . . . . 13

5. Surficial sedimentary stratigraphy in pit 15. . . . . 15

6. Depth profile of carbonate content for pit 15 samples... . . . . . . . . . . . . . . 16

7. Thickness and lateral extent of sedimentary interflow beds at the Radioactive Waste Management Complex:

A) interbed at 9-m depth; B) interbed at $34-\mathrm{m}$ depth; and $C$ ) interbed at 73-m depth. . . . . . . 25

8. Photograph of mineral deposits in vesicles

immediately below a basalt flow contact in well

$76-1$, at a depth of 28.13 meters. . . . . . . . . 29

9. Photograph of mineral deposits in vesicles

immediately below a basalt flow contact in well

76-2, at a depth of 28.42 meters. . . . . . . . 30 
10. Depth to perched ground-water zones, either observed or reported in driller's logs, in the vicinity of the Radioactive Waste Management Complex . . . . . . . . . . . . . . . . . 44

11. Location of selected production and observation wells at the Idaho National Engineering Laboratory. . . . . . . . . . . . . . . . . . 47

12. Plot of $\delta \mathrm{D}_{\text {SMOW }}$ as a function of $\delta^{18} \mathrm{O}_{\text {SMOW }}$ values for Idaho Falls precipitation samples (September 1976-October 1977). . . . . . . . . . . . . . 51

13. Seasonal variations in $\mathrm{P}_{\mathrm{CO}_{2}}$ and ${ }^{13} \mathrm{C}$ content in soil gas samples, National Oceanic \& Atmospheric Administration weather station, Central Facilities Area: A) Plot of $\log \mathrm{P}_{\mathrm{CO}_{2}}$ values as a function of time for shallow probes; and $B$ ) Plot of $\delta^{13} \mathrm{C}$ values as a function of time for shallow probes. . . . . . . . . . . . . . 57

14. Relation of $\delta D$ to $\delta^{18} 0$ for ground-water samples from selected wells in the Idaho National Engineering Laboratory vicinity . . . . . . . . . . 64

15. Values of $\delta^{13} \mathrm{C}$ and $\delta^{18} 0$ as a function of depth for pit 15 samples. . . . . . . . . . . . . 69

16. Relation of $\delta^{18}$ of clay minerals with reference to depth in well 76-3................ 73

17. Relation of $\delta^{13} \mathrm{C}$ with reference to depth for all analyzed carbonate samples from the Radioactive Waste Management Complex vicinity . . . . . . . . 76

18. Relation of $\delta^{18} 0$ with reference to depth for all analyzed carbonate samples from the Radioactive Waste Management Complex vicinity . . . . . . . . 77 


\section{TABLES}

Page

Table 1. Depths to tops and bottoms, and thicknesses (in meters) of sedimentary units in wells at the RWMC . . . . . . . . . . . . . . . . 12

2. Average median grain size for surficial and

interflow sedimentary units in wells at the RWMC. . 18

3. Particle-size distribution for EWR subpit samples . . 19

4. Bulk mineralogy for EWR subpit samples. . . . . . . . 20

5. Clay mineralogy of selected surficial sedimentary samples . . . . . . . . . . . . . . . . . . 21

6. Comparison of bulk and clay mineralogy of various sedimentary units at the RWMC . . . . . . . . . . 32

7. Semi-quantitative bulk-sediment analyses of selected samples from well 76-3............... 35

8. Clay mineral content of sedimentary samples from well 76-3... . . . . . . . . . . . . . . . . 39

9. Chemistry of the snowpack and average atmospheric precipitation at selected locations - February 2, 1978 .

10. $\delta D_{\text {SMOW }}$ and $\delta{ }^{18} O_{\text {SMOW }}$ values for Idaho Falls precipitation samples... . . . . . . . . . . . 50

11. Chemistry of a water sample from the Big Lost River, collected near Butte City, December 7, 1977 . . . . 54

12. INEL soil gas data, collected at the NOAA weather station, CFA. . . . . . . . . . . . . . . 56

13. Chemical analyses of perched ground-water samples from well 92.. . . . . . . . . . . . . . . . . . . 61

14. Stable isotope content of perched ground-water samples.... . . . . . . . . . . . . 62

15. Stable isotope content of Snake River Plain aquifer ground-water samples collected during September 1977

16. Mineral saturation calculations for perched groundwater samples taken from well 92. . . . . . . 66 
17. Stable isotope and carbonate content of carbonaterich surficial sedimentary material-pit 15. . . . 68

18. Stable isotope content of clay and carbonate in cored sedimentary material from well 76-3... . . 72

19. Carbonate and stable isotope content of carbonatebearing sedimentary samples... . . . . . . 75

FACTORS FOR CONVERTING INCH-POUND UNITS TO METRIC (SI) UNITS

The following factors can be used to convert the International System (SI) of metric units published herein to inch-pound units.

\section{Multiply metric units}

$$
\begin{aligned}
& \text { angstrom }(A 0) \\
& \text { centimeter }(\mathrm{cm}) \\
& \text { meter }(\mathrm{m}) \\
& \text { kilometer }(\mathrm{km})
\end{aligned}
$$$$
\text { square meter }\left(\mathrm{m}^{2}\right)
$$$$
\text { square kilometer }\left(\mathrm{km}^{2}\right)
$$$$
\text { cubic meter }\left(\mathrm{m}^{3}\right)
$$$$
\text { cubic meter }\left(\mathrm{m}^{3}\right)
$$$$
\text { cubic meter }\left(\mathrm{m}^{3}\right)
$$$$
\text { microsiemen ( } \mu \mathrm{S})
$$$$
\text { temperature, degrees Fahrenheit }
$$

By

$$
\begin{aligned}
& 3.937(10)^{-9} \\
& 0.3937 \\
& 3.281 \\
& 0.6215
\end{aligned}
$$$$
10.76
$$$$
0.3861
$$$$
264.2
$$$$
2.642(10)^{-4}
$$$$
8.110(10)^{-4}
$$$$
1.00
$$

To obtain inch-pound units

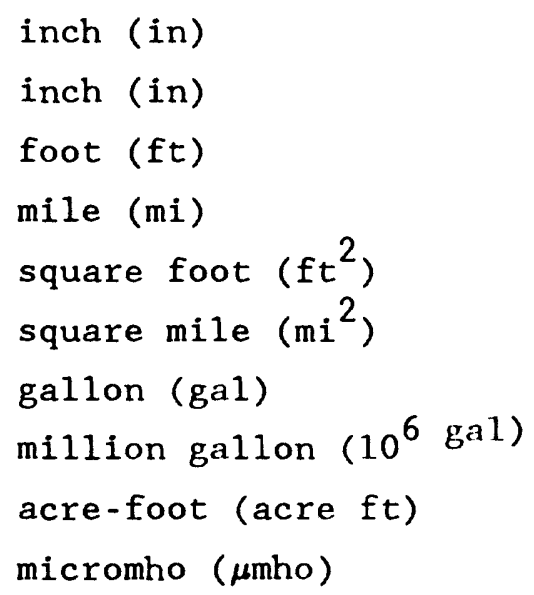

The use of trade names in this report is for identification purposes only and does not constitute endorsement by the U.S. Geological Survey. 


\title{
HYDROGEOLOGY AND GEOCHEMISTRY OF \\ THE UNSATURATED ZONE, RADIOACTIVE WASTE MANAGEMENT COMPLEX, IDAHO NATIONAL ENGINEERING LABORATORY, IDAHO
}

\author{
by \\ Craig T. Rightmire, formerly U.S. Geological Survey \\ and \\ Barney D. Lewis, U.S. Geological Survey
}

\begin{abstract}
To assess the potential migration of low-level radioactive waste in the shallow subsurface, it is necessary to understand the chemical interactions that occur between solids, liquids, and gases in the unsaturated zone. For this purpose, a study on the geochemistry of the unsaturated zone at the Radioactive Waste Management Complex (RWMC), Idaho National Engineering Laboratory, on the eastern Snake River Plain in southeastern Idaho was done.

Stable isotope and chemical data suggest that the perched water observed beneath the RWMC is not due to vertical infiltration through the ground surface at the RWMC, but is due to lateral flow of water that infiltrated through the diversion ponds. It is hypothesized that the water accumulates as a perched mound on the thick, laterally continuous sedimentary interbed at a depth of 73 meters (m) and then moves about 1.5 kilometers to the northeast beneath the RWMC. Infiltrating water can move clay, silt, and sand downward through sedimentary material and open fractures, at least to the interbed at a depth of $73 \mathrm{~m}$.

Oxygen isotope exchange and clay mineral alteration caused by extruded lava have been observed in the upper $0.86 \mathrm{~m}$ of the sedimentary interbed at a depth of $34 \mathrm{~m}$ and in the upper $2.65 \mathrm{~m}$ of the sedimentary interbed at a depth of $73 \mathrm{~m}$. An examination of the sediment-basalt interrelation shows that the flows overlying the interbed at a depth of $73 \mathrm{~m}$ are substantially
\end{abstract}


thicker than the flows overlying the interbed at a depth of $34 \mathrm{~m}$ (16 to $23 \mathrm{~m}$ compared to 6 to $10 \mathrm{~m}$ ). Therefore, a greater influence of residual heat on the sedimentary unit that underlie the thicker flows, and thus greater alteration, may be expected. Sedimentary material at the RWMC shows isotopic and soils evidence of at least two major climatic changes within the last 200,000 years.

\section{INTRODUCTION}

The Radioactive Waste Management Complex (RWMC) is located at the Idaho National Engineering Laboratory (INEL) on the eastern Snake River Plain in southeastern Idaho (fig. 1). The INEL is composed of about $2,300 \mathrm{~km}^{2}$ of semiarid sagebrush covered terrain on the northwest side of the plain.

The plain is an arcuate topographic depression that traverses southern Idaho for a distance of approximately $500 \mathrm{~km}$. It ranges from 50 to $100 \mathrm{~km}$ wide and rises from about $700 \mathrm{~m}$ in altitude on the west to about $2,000 \mathrm{~m}$ in the east. The eastern Snake River Plain is bounded on the west, north, and east by mountain ranges and high plateaus. Many of the high peaks in these ranges exceed $3,500 \mathrm{~m}$ in altitude. Alluvial valleys that drain the mountain ranges to the north and northwest drain onto the plain and the INEL.

The RWMC is situated in the southwestern part of the INEL, $5.6 \mathrm{~km}$ north of the INEL's southern boundary (fig. 2). It is in a sediment-filled topographic depression at an altitude of about $1,527 \mathrm{~m}$, and the sedimentary unit is underlain by basalt lava flows.

To the west and south of the RWMC are water diversion ponds into which water from the Big Lost River is channeled at times of high flow to prevent flooding of facilities downstream on the INEL, or to prevent ice buildup during the winter. These ponds have a capacity for storing about $2.22(10)^{7} \mathrm{~m}^{3}$ of water. Diversion area $A(f i g .2)$ is at an altitude of $1,537 \mathrm{~m}$ whereas areas, $\mathrm{B}, \mathrm{C}$, and $\mathrm{D}$ are at $1,536 \mathrm{~m}$. A dike in diversion area $B$, with an altitude of $1,538 \mathrm{~m}$, is located $1 \mathrm{~km}$ southwest of the southern boundary of the RWMC. 


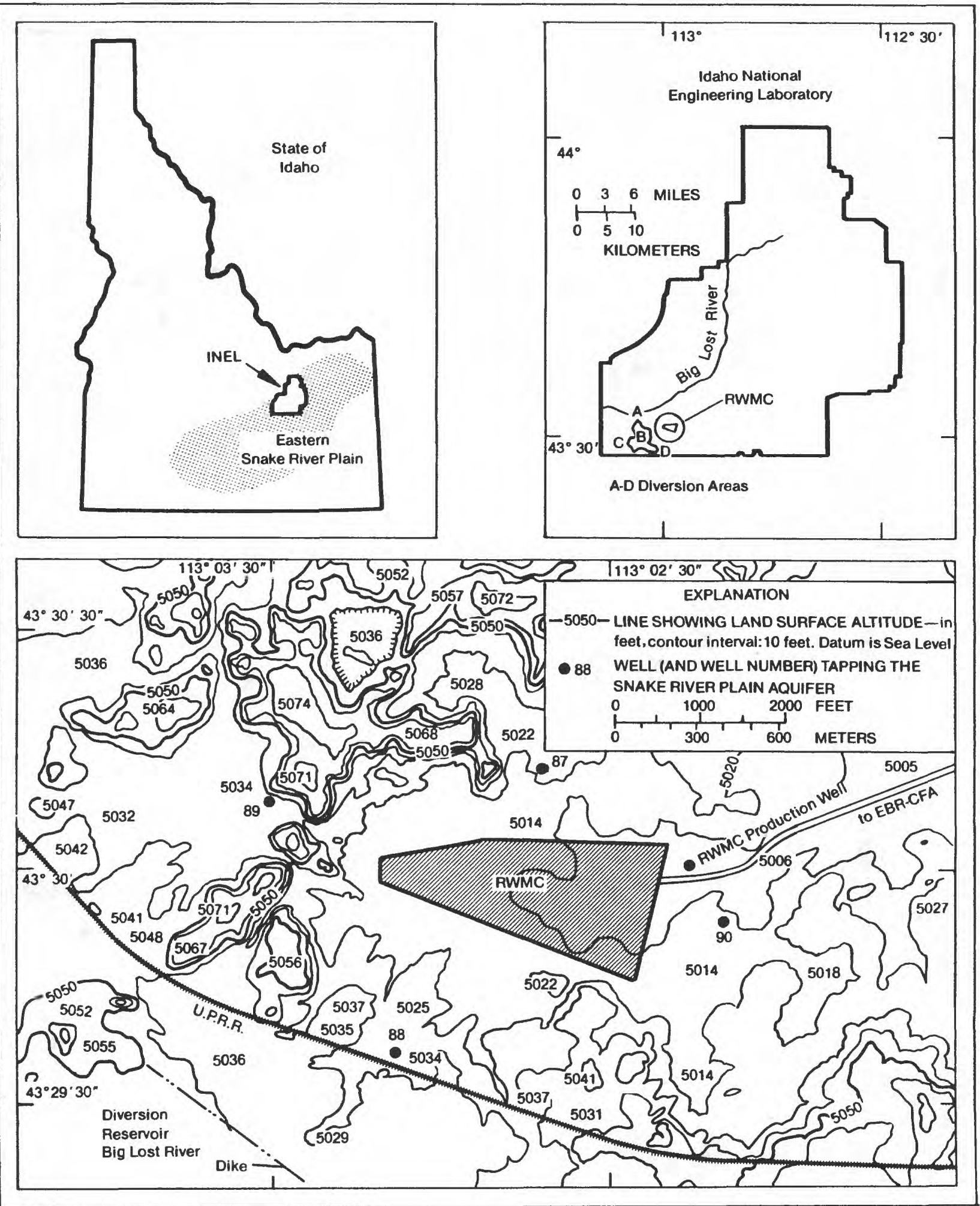

Figure 1.--Location of the Idaho National Engineering Laboratory and eastern Snake River Plain, and the relation of the Radioactive Waste: Management Complex and adjacent wells to the diversion areas and the Big Lost River (from Rightmire, 1984). 


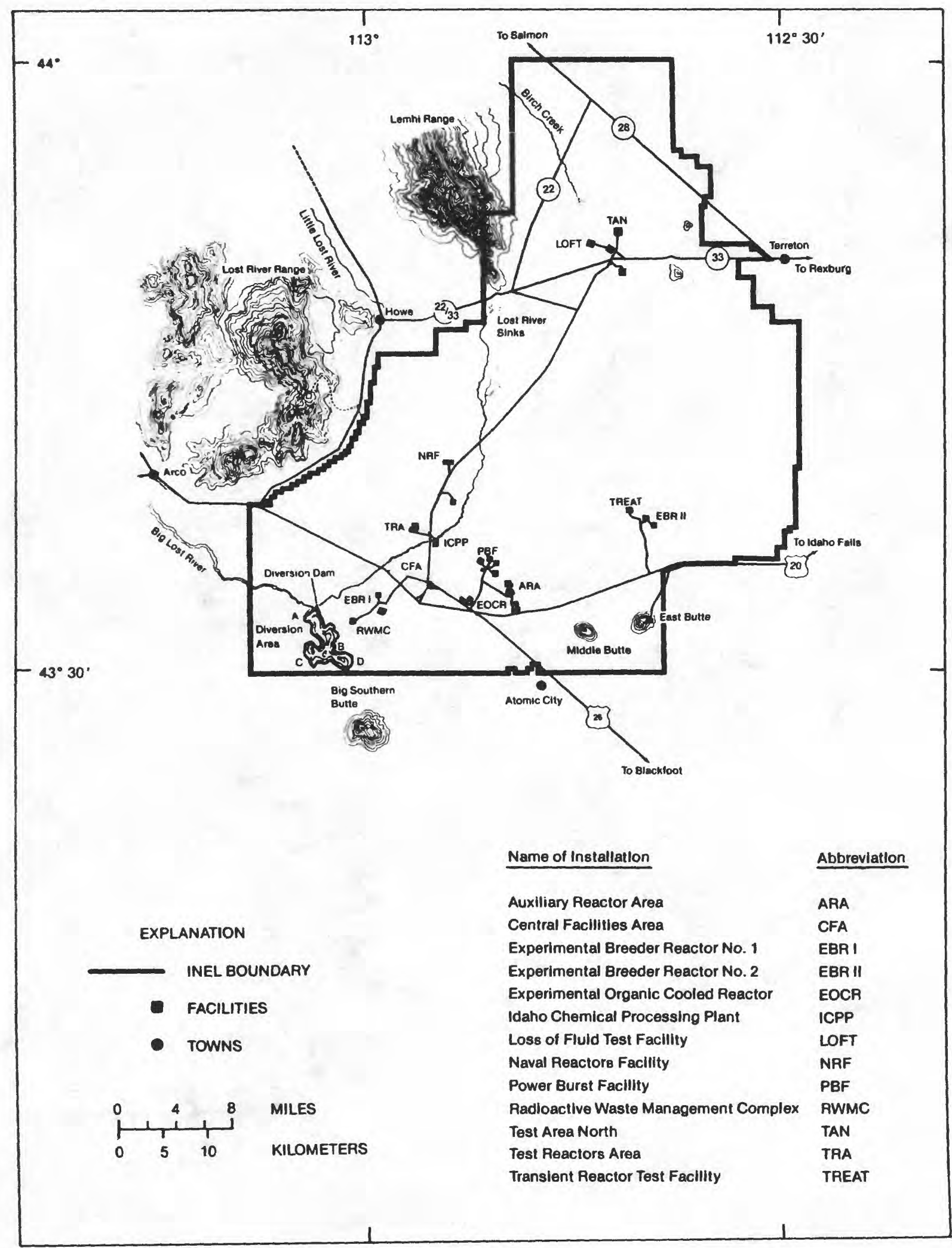

Figure 2.--Location of selected Idaho National Engineering Laboratory facilities (modified from Bagby and others, 1984). 
PURPOSE AND SCOPE

This report describes the results of a study to develop a conceptual model of the hydrogeochemical environment of the shallow unsaturated zone of the Snake River Plain, eastern Idaho, and to determine how changes in that environment may influence the mobility and migration of waste radionuclides buried in the subsurface disposal area of the RWMC (fig. 3).

The data collected and the interpretations made therefrom have been compiled in a series of three reports: 1) A published report by Rightmire and Lewis (1987) that documents the data collected and analytical methods used during the course of this investigation; 2) The hydrogeologic and geochemical interpretations made from collected data and analytical methods (this report); and 3) A planned report that documents how changes in the environment may influence the mobility and migration of waste radionuclides.

Samples of rain and snow were collected for chemical and isotopic analyses to provide background information on the principal chemical input to the system. Core material was examined and thin sections were studied to determine the mode of emplacement and/or formation of fracture filling or lining materials, chiefly clay minerals and calcium carbonate, as an aid to estimate how much water has moved through the unsaturated zone. X-ray mineralogic analyses were made on surficial sediment, interflow sediment, and fracture filling sedimentary material to facilitate the determination of the origin of sediment. Carbonate content and carbon and oxygen-isotope ratios of the calcium carbonate in sedimentary material have been determined to help ascertain sedimentary surface stability and age.

\section{PREVIOUS INVESTIGATIONS}

The U.S. Geological Survey has done geologic and hydrologic studies at the INEL since the area was selected for a reactor testing area by the U.S. Atomic Energy Commission in 1949. These studies include the physical environment (Nace, Deutsch, and Voegeli, 1972), the generalized geologic framework (Walker, 1964; Nace and others, 1975), the hydrology (Olmsted, 


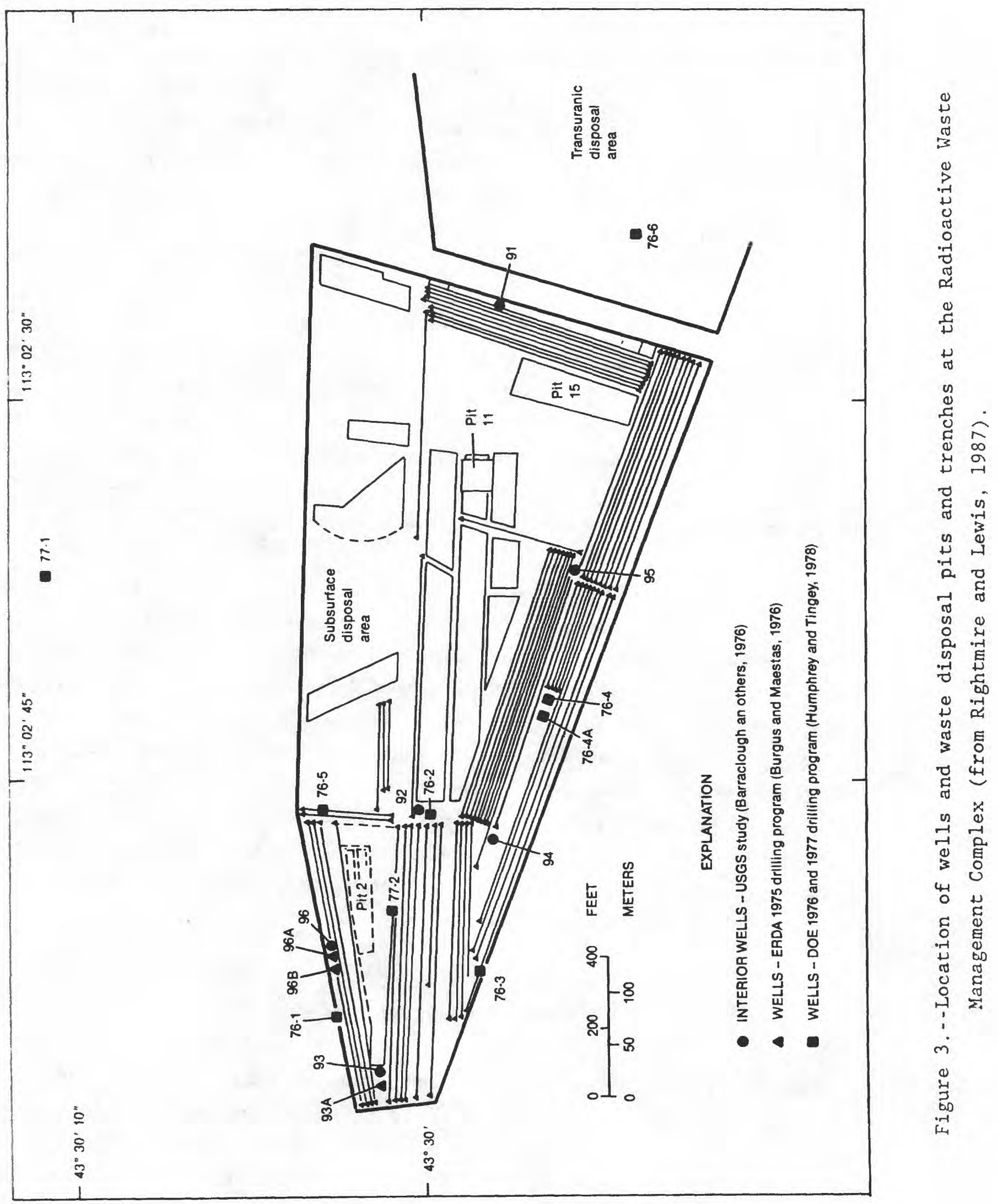


1962; Mundorff, Crosthwaite, and Kilburn, 1964; Barraclough, Teasdale, and Jensen, 1967; Barraclough and others, 1967), and the geochemistry (Robertson, Schoen, and Barraclough, 1974; Rightmire and Martin, written commun., 1984).

Investigations in the vicinity of the RWMC have been discussed in several reports. These studies include hydrologic and potential radionuclide migration studies at the RWMC carried out by the U.S. Geological Survey between 1971 and 1974 (Barraclough, Robertson, and Janzer, 1976), during which ten wells were drilled; another three wells drilled during a study on the radionuclide analyses of collected sediment samples completed during 1975 at the RWMC (Burgus and Maestas, 1976); and a study of radionuclide content of sediment samples from trenches below waste pits (Humphrey and Tingey, 1978) during which nine additional wells were drilled. Physical and selected chemical characteristics of core and subpit samples were documented by Rightmire and Lewis, 1987. Figure 3 shows the locations of selected wells drilled during these various studies at the RWMC and the locations of the disposal trenches and pits. The data utilized herein for evaluating sedimentary environments were derived from samples collected from the 22 wells completed during these three drilling programs.

Six of these wells $(87,88,89,90,76-6$ and 77-1) drilled outside the RWMC helped define the hydrogeologic environment in the surrounding vicinity (see figures 1 and 3 for well locations). Several wells, those designated with alphabetic suffixes, were drilled adjacent to holes which had to be abandoned due to operational problems $(76-4 \mathrm{~A})$ or to provide additional cored material in the vicinity of holes drilled during previous drilling programs (93A, 96A, and 96B).

\section{ACKNOWLEDGMENTS}

These studies were sponsored and funded by the Energy Research and Development Administration, now the Department of Energy and were coordinated through the Idaho Operations office (IDO). Considerable assistance has been obtained from the following IDO personnel: M.M. 
Williamson, Director, Radiological and Environmental Sciences Laboratory; the staff of the Analytical Chemistry Branch, L.Z. Bodnar, Chief, who provided most of the radiometric analyses of ground-water samples; and E.W. Chew, Chief, Environmental Sciences Branch.

\section{GEOLOGY}

\section{REGIONAL DESCRIPTION}

The eastern Snake River Plain is underlain by a thick sequence of basaltic rocks and interbedded sedimentary layers, and all are included in the Snake River Group of Quaternary age (Lewis and Goldstein, 1982). The basement rocks are probably composed of older volcanic and sedimentary rocks, in addition to underlying crystalline rocks.

The plain in the vicinity of the INEL is bounded on the northwest and southeast by fault-block mountains of the Basin and Range province. Most of these ranges trend northwest-southeast approximately normal to the long axis of the plain. The fault-block mountains to the northwest of the plain are composed primarily of block-faulted sequences of Paleozoic carbonate rocks. The fault-block mountains to the southeast differ from those to the northwest in that they consist chiefly of Mesozoic marine and non-marine siltstones and shales and contain a smaller amount of Paleozoic carbonate rocks.

The fault-block mountains end abruptly on both the northwestern and southeastern plain margins suggesting that they are truncated by boundary faults parallel to these margins. Volcanic rift zones paralleling the block-fault trends, normal to the axis of the plain, have been identified on the plain and are believed to be surface expressions of extensions of the range-front faults (Kuntz, 1977a).

The plain is the site of three rhyolite domes, East Butte, Middle Butte, and Big Southern Butte located near the southern boundary of the INEL (fig. 2). Two of these buttes, East and Big Southern, are rhyolitic domes 
that were extruded through the basalt pile. Middle Butte is completely capped by basalt and basalt talus but, based on geophysical evidence (Mabey, Peterson, and Williams, 1974) is believed to be underlain by rhyolite.

The basalt lava flows of the eastern Snake River Plain are thought to be underlain by silicic volcanic rocks, which are exposed locally on the plain margins and range in age from $10 \mathrm{~m} . \mathrm{y}$. to less than $1 \mathrm{~m} . \mathrm{y}$. (Christiansen and Blank, 1972).

The regional geology of the RWMC area is described in detail by Robertson, Schoen, and Barraclough (1974), and by Kuntz (1978a). A discussion emphasizing the sedimentary materials and the water chemistry to their source areas will be included here.

\section{BASALTIC VOLCANISM}

Basaltic volcanism has been a dominant geologic process on the eastern Snake River Plain for the last 3.5 million years (m.y.). Kuntz (1977a; 1977b) has shown that nearly all of the Pleistocene and Holocene volcanoes are rift- or fissure-controlled. Based on magnetic polarity studies, nearly all the surface flows on the plain have been determined to be less than 700,000 years old. K-Ar dates by Dalrymple (Kuntz, 1978a) indicate that five overlapping flows penetrated by drill cores ( $40 \mathrm{~m}$ holes) in the vicinity of EBR-II (see fig. 2 for location) range in age from less than $135,000 \pm 38,000$ years to $341,000 \pm 30,000$ years. Surface flows on the INEL have been shown by radiocarbon dating to be as young as $10,780 \pm 300$ years (Kuntz, 1978b). The most recent volcanism on the plain has been reported for flows in the Craters of the Moon lava field at $2,050 \pm 80$ to $2,200 \pm 30$ ${ }^{14} \mathrm{C}$ years ago (Valastro, Davis, and Varela, 1972).

The thickness of the individual flows observed in cores ranges from $1.8 \mathrm{~m}$ to $23.0 \mathrm{~m}$. It is likely that the greater thicknesses are due to the ponding of fluid basalt in depressions on the surface of the underlying flow. Normally, flows on the eastern Snake River Plain do not exceed $10 \mathrm{~m}$ in thickness. 
The basalts of the eastern Snake River Plain were generally extruded in non-violent eruptions, yielding fluid flows of pahoehoe lava. A few cinder cones and aa lava flows are observed in the area. The basalts have the chemical characteristics of both tholeiitic and alkali olivine basalts. They are of low-silica and high iron contents and indicate liquid temperatures of approximately 1,050 oC (Stout and Nicholls, 1977). These basalts are generally medium to dark gray in color. They range from vesicular, with elongated vesicles up to $4 \mathrm{~cm}$ in length, to dense. Olivine ( Fo $_{50}$ to Fo 90 ), plagioclase (averaging An 65 , the composition of labradorite), and a clinopyroxene, tentatively identified as augite, are the dominant mineral phases present. Magnetite and ilmenite are present and approximately equal in abundance (Kuntz and other, 1980). Stout and Nicholls (1977) state that the augite contains 18.8 percent $\mathrm{CaO}$ and that opaque minerals constitute between 7 and 21 percent of the rock. With the exception of some Craters of the Moon lava flows, the most recent on the plain, there are no significant differences in chemical or mineralogical composition related to age or geographic location on the plain.

A sequence of 13 lava flows and flow units have been observed between land surface and $183.9 \mathrm{~m}$ in coreholes drilled at the RWMC. The oldest of these flows is about 500,000 years. The average rate of inundation of the RWMC by a closely spaced group of flows is approximately once every 70,000 years (Kuntz and others, 1980).

The uppermost basalt surface at the RWMC is made up of two different flows. Kuntz and others (1980) state that 90 percent of the area of the RWMC is immediately underlain by basalt flows less than 200,000 years old which originated from fissure controlled vents located about $5 \mathrm{~km}$ north of Big Southern Butte and $5 \mathrm{~km}$ south of the RWMC. The remaining 10 percent is underlain by a flow approximately 100,000 years old. This youngest flow originated at Quaking Aspen Butte, about $17 \mathrm{~km}$ to the southeast and forms the topographic ridge to the west and north of the RWMC which Kuntz and others (1980) believe may follow an old channel of the Big Lost River. 


\section{SEDIMENTARY DEPOSITS}

The basalt flows are commonly interbedded with and overlain by alluvial, lacustrine, and eolian sediments deposited on the eastern Snake River Plain. These sedimentary deposits are composed largely of fine sand, silt, and clay. In present and abandoned stream channels and areas affected by flooding, a significant amount of limestone, quartzite, and basalt pebbles are found.

Alluvial sedimentary deposits were accumulated in depressions on or adjacent to basalt flows during times of high runoff. Lava flows in the past have dammed stream channels causing small lakes, in which much of the finer sediment is deposited. Water infiltrating the lava flows will carry fine sediment in suspension and deposit it on fracture walls. Occasional major floods may carry the coarser silt and sand into the fractures, in extreme cases causing collapse (depression) features in the sedimentary surface (that is, piping).

The mineralogic composition of the sedimentary material is derived from parent material in the mountains surrounding the plain or from alteration products of basalt and includes quartz, plagioclase, potassium feldspars, clinopyroxenes, olivine, chlorite, and various clay mineral assemblages.

The depth of the core holes, land surface elevation, surficial sediment thickness, and depth to tops and thicknesses of the observed interbeds underlying the RWMC are given in table 1.

\section{Surficial Deposits}

The entire surface area of the RWMC is covered by eolian and alluvial deposits which range in thickness from less than 0.6 to more than $7.3 \mathrm{~m}$. This irregularity in thickness is due primarily to the irregularity of the surface of the underlying basalt. Figure 4 shows the thickness of the surficial material, determined from auger holes and driller's logs, for the entire burial ground. 


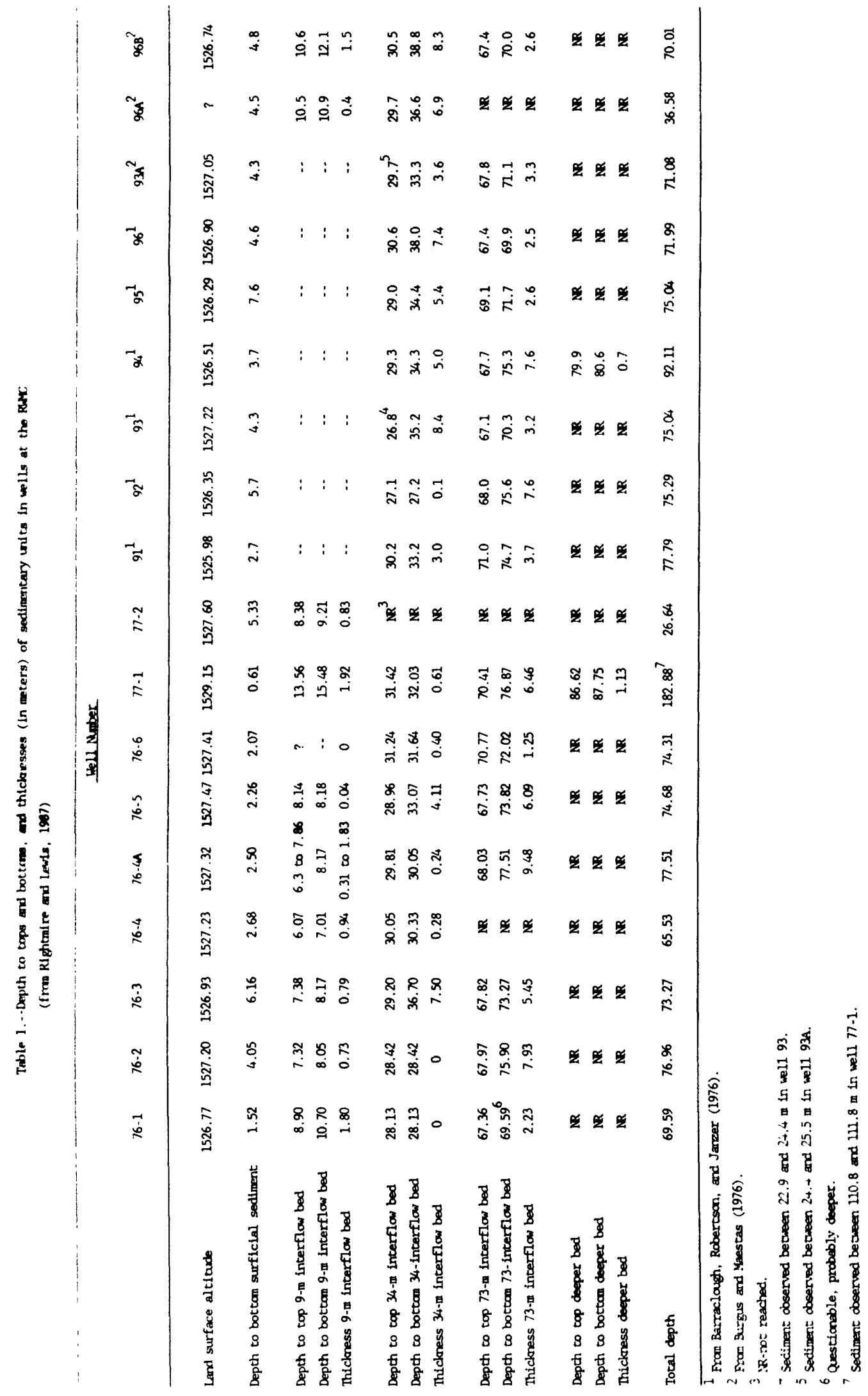




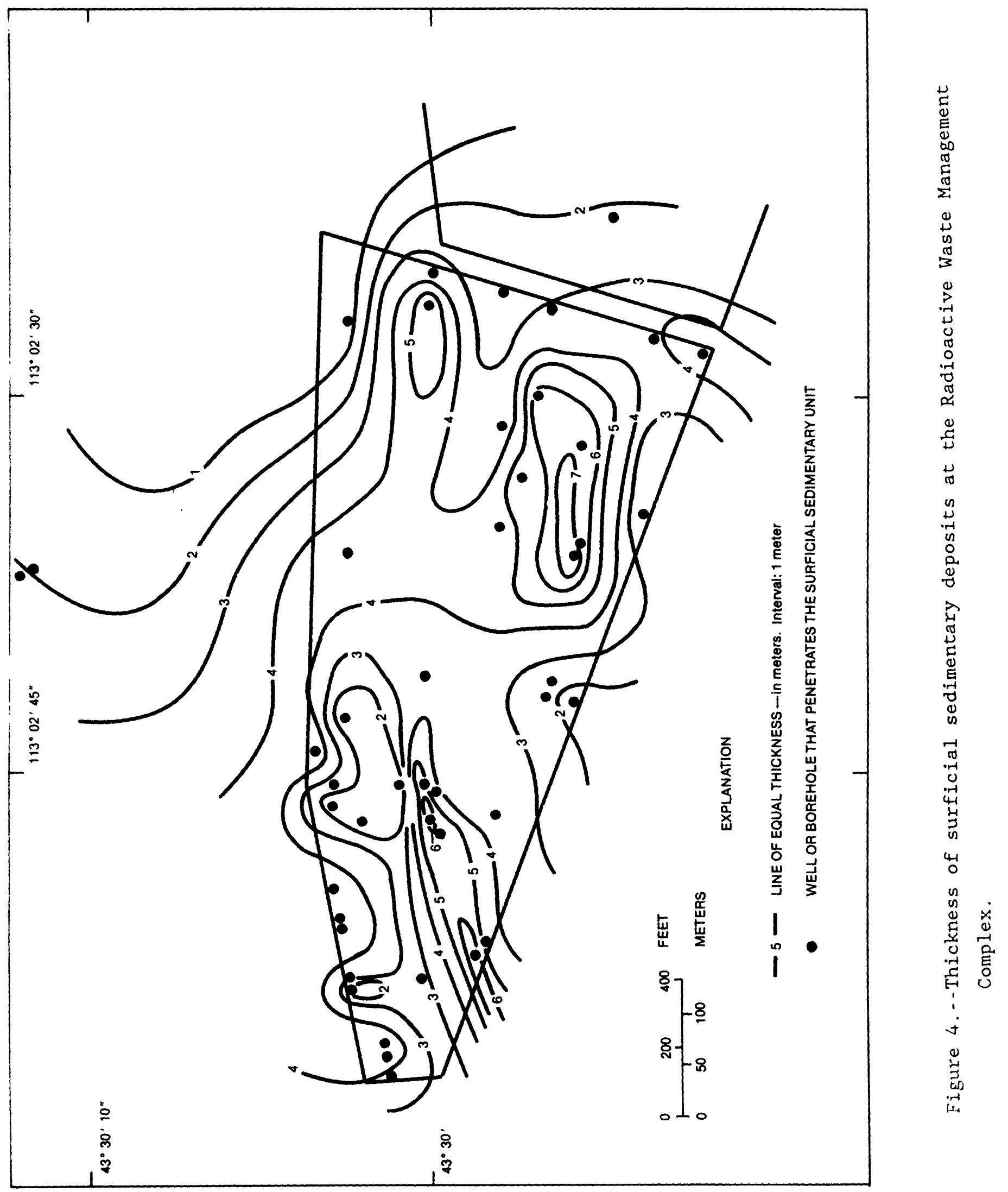


Most of the alluvial material at the RWMC was transported down the Big Lost River Valley in times of high runoff. Barraclough, Robertson, and Janzer (1976) hypothesized that the RWMC was in the flood plain of the Big Lost River prior to the Quaking Aspen Butte eruption. The presence of gravel in the surficial sediments (Burgus and Maestas, 1976) supports this hypothesis. The eolian material was probably derived from the finer fraction of alluvial deposits located to the southwest, in the windward directions.

In addition to cored samples, surficial sedimentary samples were collected at several locations within the RWMC to lithologically and geochemically characterize the sedimentary material and relate these characteristics to those observed in sedimentary interbeds.

Sedimentary samples were obtained from trenches excavated beneath pit 2 (see fig. 3), which was utilized from 1959 through 1963 for the burial of transuranic waste. These samples are designated EWR samples for their locations beneath Early Waste Retrieval (EWR) pits. Samples were collected at approximately $0.3-\mathrm{m}$ intervals down the east wall of pit 15 from 0.6 to $5.3 \mathrm{~m}$. These samples were analyzed for carbonate content and for carbon and oxygen isotope content of the carbonate.

\section{Stratigraphy}

Examination of a $5.5-\mathrm{m}$ high vertical wall in pit 15 (see figure 3 for iocation) indicates that there are distinct stratigraphic units within the surficial sediment. It is impossible to determine the lateral extent of these units without an extensive drilling program.

The stratigraphic sequence observed in pit 15 at the RWMC is given in the generalized section in figure 5 . This sequence of sedimentary material shows the development of two reddish-brown paleosols, one between 2.13 and $2.90 \mathrm{~m}$ and a second between 4.33 and $5.55 \mathrm{~m}$. These paleosol units contain some of the lowest amounts of carbonate in the section (fig. 6) suggesting that paleosol development occurred in a wetter period during which carbonate 


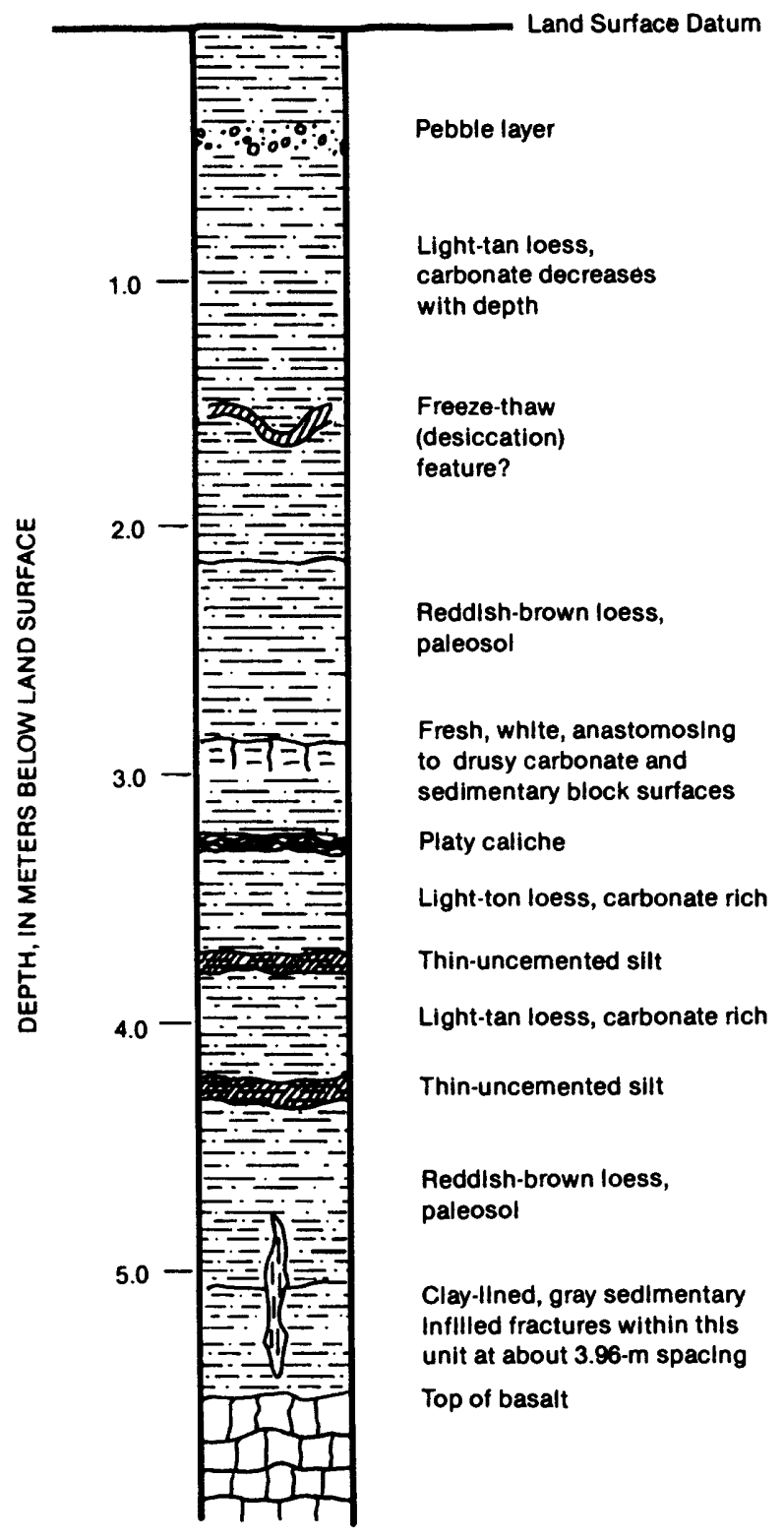

Figure 5.--Surficial sedimentary stratigraphy in pit 15 . 


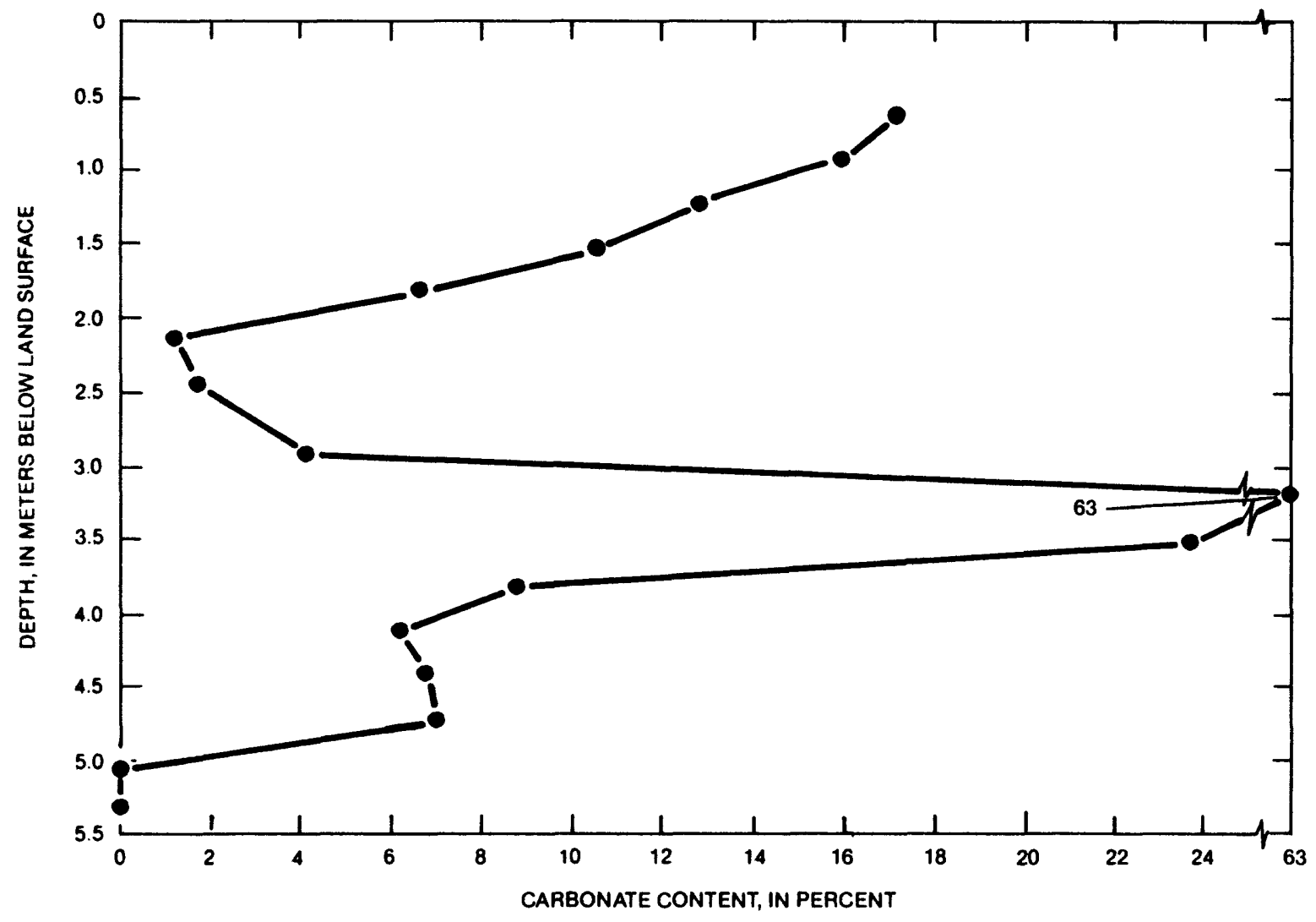

Figure 6.--Depth profile of carbonate content for pit 15 samples. 
was leached from the soil and the sedimentary mineralogy altered to produce the reddish-brown color. Some thin (less than $10 \mathrm{~cm}$ ) uncemented units occur within the light tan loess, and may be volcanic ash fall deposits.

The carbonate content ranges from zero to 63 percent with two stages of carbonate development readily recognizable (fig. 6). The oldest stage culminated with the formation of a platy caliche layer found at a depth of $3.2 \mathrm{~m}$. The youngest carbonate is accumulating at present in response to recent climatic conditions at land surface.

Wedge shaped distortions, with rounded bottoms, were observed in bedding at a depth of approximately $1.5 \mathrm{~m}$. It has been suggested that similar features observed in Owl Cave at the Wasden Archaeological Site might be due to ice-wedging (Dort and Miller, 1977).

A series of thin, less than $10 \mathrm{~mm}$, regularly spaced vertical fractures were observed in the sediment below $4.7 \mathrm{~m}$. The fractures are of uniform width, are clay lined, and are filled with different sedimentary material than that cut by the fracture. The spacing of the fractures is about $4 \mathrm{~m}$. These fractures may be similar to those discussed by Nace and others (1975, p. 38-39) which reached the basalt surface at a depth of $15.5 \mathrm{~m}$. The lower terminus of the fractures was not observed but because of the uniformity of width and proximity of the sediment-basalt contact (approximately $1 \mathrm{~m}$ below the base of trench) it is felt that they also reach the first basalt flow.

\section{Particle-Size Distribution}

Particle-size analysis (table 2) data from Barraclough, Robertson, and Janzer (1976) and the current study show that surficial sedimentary material and the interflow sedimentary bed samples, have an average median grain size of less than $1 \mathrm{~mm}$. The surface sedimentary material is the finer size fraction.

Eleven particle-size analyses have been done on samples of surficial sedimentary material in the vicinity of the RWMC. The shallowest samples 
reported by Barraclough, Robertson, and Janzer (1976, p. 119) contain no particles larger than $1.0 \mathrm{~mm}$ and contain between 70.0 and 95.2 percent material less than $62 \mu \mathrm{m}$. Although there are a few minor sand and gravel lenses present (Burgus and Maestas, 1976), it appears that the surficial sediment in the vicinity of the RWMC is predominantly silt and clay sized material.

Four series of samples were collected $0.3 \mathrm{~m}$ apart in a vertical profile from three subpits beneath the floor of pit 2. The four deepest samples, from series EWR-1, were submitted to the U.S. Geological Survey Hydrologic Laboratory, Denver, Colorado, for particle size, bulk and clay mineralogy, carbonate content, and cation-exchange capacity analyses.

Table 2.--Average median grain size for surficial and interflow sedimentary units in wells at the RWMC

\begin{tabular}{|c|c|c|c|}
\hline $\begin{array}{l}\text { Sedimentary } \\
\text { deposit }\end{array}$ & $\begin{array}{l}\text { Number of } \\
\text { analyses }\end{array}$ & $\begin{array}{r}\text { Average } \\
\text { grain } \\
(\mathrm{mn}\end{array}$ & $\begin{array}{l}\text { median } \\
\text { size } \\
\text { ) }\end{array}$ \\
\hline Surficial bed ${ }^{1}$ & 7 & 0.023 & \pm 0.027 \\
\hline ... - Do ... & 4 & 0.0083 & \pm 0.0084 \\
\hline $9-m$ interflow bed & 4 & 0.07 & \pm 0.13 \\
\hline $34-m$ interflow bed ${ }^{1}$ & 10 & 0.18 & \pm 0.33 \\
\hline -... - Do-.. & 10 & 0.82 & \pm 1.35 \\
\hline $73-\mathrm{m}$ interflow bed 1 & 23 & 0.043 & \pm 0.048 \\
\hline -...-Do-... & 8 & 0.41 & \pm 0.95 \\
\hline
\end{tabular}

From Barraclough, Robertson, and Janzer (1976). 
Particle-size analysis for the four deeper EWR samples indicates that from 71.1 to 94.8 percent of the material is in the silt and clay size fraction (less than $62.5 \mu \mathrm{m}$ ) with up to 54.7 percent in the less than $4 \mu \mathrm{m}$ size fraction--near clay size (table 3 ). No particles coarser than coarse sand $(0.5$ to $1 \mathrm{~mm})$ were reported in these samples. Statistical characteristics for the grain-size analysis are given in table 3.

Al1 the surficial sedimentary material observed in this study contains detrital material no coarser than coarse sand (less than $1 \mathrm{~mm}$ ). The reported occurrence of gravel in surficial material (Burgus and Maestas, 1976) suggests that a water course with at least occasional flow capable of moving gravel traversed the area of the RWMC since the influx of the underlying lava flow about 200,000 years ago (Kuntz and others, 1980). The evidence that a water channel flowing through the RWMC within the last 75,000 years is enhanced by the presence of two "wind gaps" in a basalt pressure ridge on a flow to the west and north of the RWMC, dated at about 75,000 years (Kuntz and others, 1980).

Table 3.-. Particle size distribution for EWR subpit samples (in percent of analyzed sample) ${ }^{1}$

\begin{tabular}{|c|c|c|c|c|c|c|c|}
\hline $\begin{array}{l}\text { Sample } \\
\text { number }\end{array}$ & $\begin{array}{l}\text { Depth } \\
\text { (in } \\
\text { meters) }\end{array}$ & $\begin{array}{c}\text { Clay } \\
<0.004 \\
\mathrm{~mm}\end{array}$ & $\begin{array}{l}\text { Silt } \\
0.004- \\
0.0625 \\
\mathrm{~mm}\end{array}$ & $\begin{array}{l}\text { Sand } \\
\text { very } \\
\text { fine } \\
0.0625- \\
0.125 \mathrm{~mm}\end{array}$ & $\begin{array}{l}\text { Sand } \\
\text { fine } \\
0.125- \\
0.25 \mathrm{~mm}\end{array}$ & $\begin{array}{c}\text { Sand } \\
\text { Medium } \\
0.25- \\
0.5 \mathrm{~mm}\end{array}$ & $\begin{array}{l}\text { Sand } 3 \\
\text { Coarse } \\
0.5-1 \mathrm{~mm}\end{array}$ \\
\hline EWR - 1 - 4 & 0.91 & 53.3 & 38.5 & 4.8 & 2.3 & 0.9 & 0.1 \\
\hline$-1-3$ & 1.22 & 41.0 & 30.1 & 11.0 & 17.7 & 0.2 & 0 \\
\hline$-1-2$ & 1.52 & 54.7 & 40.1 & 4.1 & 0.7 & 0.2 & 0.1 \\
\hline EWR - 1 - 1 & 1.83 & 23.5 & 69.8 & 6.0 & 0.6 & 0 & 0.1 \\
\hline
\end{tabular}

1 Analyzed by the U.S. Geological Survey Hydrologic Laboratory, Denver, Co.

2 All samples from surficial deposits.

${ }^{3}$ No particles coarser than $1 \mathrm{~mm}$ observed. 
Loess, windblown sedimentary material with a general size range of from 20 to $100 \mu \mathrm{m}$ (fine silt to very fine sand), is a major part of the surficial material present at the RWMC. It is suspected that loess on the Snake River Plain was derived in the mountains to the west during periods of glacial activity (pluvial periods), and moved by alluvial processes to the plain, where the wind distributed it under drier climatic conditions.

Sedimentary units with large amounts of clay-size material suggest that the areas in which they were deposited may at times have been topographic depressions in which runoff water or stream flood water carrying suspended sedimentary material accumulated and the sedimentary material settled out.

\section{Mineralogy}

The bulk mineralogy of the EWR samples determined by X-ray diffraction indicates that, with one exception, clay minerals and quartz are the dominant minerals present (table 4). In the one exception, sample EWR-1-2, calcite is the dominant mineral phase. Accessory minerals identified include potassium feldspar, plagioclase feldspar, and a pyoxene (diopside?).

Table 4.--Bulk mineralogy for EWR subpit samples

(in percent of analyzed sample) ${ }^{1}$

\begin{tabular}{|c|c|c|c|c|c|c|c|c|}
\hline $\begin{array}{l}\text { Sample } \\
\text { number }\end{array}$ & $\begin{array}{l}\text { Depth } \\
\text { (in } \\
\text { meters) }\end{array}$ & Quartz & $\begin{array}{l}\text { Potas- } \\
\text { sium } \\
\text { feld- } \\
\text { spar }\end{array}$ & $\begin{array}{l}\text { Plagio- } \\
\text { clase }\end{array}$ & $\begin{array}{l}\text { Cal- } \\
\text { cite }\end{array}$ & $\begin{array}{l}\text { Pyrox- } \\
\text { ene } \\
\text { (diop- } \\
\text { side?) }\end{array}$ & $\begin{array}{l}\text { Clay } \\
\text { miner- } \\
\text { als }\end{array}$ & $\begin{array}{l}\text { Total } \\
\text { per- } \\
\text { cent }\end{array}$ \\
\hline EWR - 1 - 4 & 0.91 & 27 & $\leq 5$ & 11 & 1 & 4 & 70 & $113 t^{2}$ \\
\hline$-1-3$ & 1.22 & 29 & $\leq 6$ & 10 & 0 & 9 & 55 & $103+$ \\
\hline$-1-2$ & 1.52 & 15 & $\leq 3$ & 6 & 41 & $\leq 9$ & 25 & $87+$ \\
\hline EWR - 1 - 1 & 1.83 & 29 & 5 & 12 & 13 & $\leq 9$ & 40 & $99+$ \\
\hline
\end{tabular}


Analyses of the less than $4 \mu \mathrm{m}$ fraction indicate that illite and mixed layer clays (illite/smectite) are the dominant phases in all four samples with relatively high smectite content in EWR-1-2 and EWR-1-1 at depths of $1.5-\mathrm{m}$ and $1.8-\mathrm{m}$ below the pit floor, respectively (table 5). No attempt was made to determine the percentage of expandable layers in the mixed-layer clays.

Table 5.--Clay mineralogy of selected surficial sedimentary samples (in percent of total clay minerals/percent of original bulk sample) ${ }^{1}$

\begin{tabular}{|c|c|c|c|c|c|c|c|c|}
\hline Sample & $\begin{array}{l}\text { Depth } \\
\text { (in } \\
\text { meters) }\end{array}$ & Cholrite & Illite & $\begin{array}{l}\text { Mixed } \\
\text { layer } \\
\text { clays } \\
\text { (illite/ } \\
\text { smectite) }\end{array}$ & Smectite & $\begin{array}{l}\text { Kaoli- } \\
\text { nite }\end{array}$ & $\begin{array}{l}\text { Cation } \\
\text { exchange } 2 \\
\text { capacity }\end{array}$ & $\begin{array}{l}\text { Carbonate } \\
\text { content } \\
\left.\text { (as } \mathrm{CaCO}_{3}\right) \\
\text { percent }\end{array}$ \\
\hline EWR $-1-4$ & +0.91 & $0 / 0$ & $36 / 25$ & $45 / 32$ & $13 / 9$ & $6 / 4$ & 27 & 0 \\
\hline $1-3$ & 1.22 & $0 / 0$ & $30 / 16$ & $48 / 26$ & $16 / 9$ & $6 / 3$ & 27 & 2.3 \\
\hline $1-2$ & 21.52 & $0 / 0$ & $36 / 9$ & $31 / 8$ & $24 / 6$ & $9 / 2$ & 11 & 36.1 \\
\hline EWR - 1 - 1 & 1.83 & $0 / 0$ & $32 / 12$ & $30 / 12$ & $26 / 10$ & $12 / 5$ & 11 & 10.8 \\
\hline
\end{tabular}

1 Analyzed by the U.S. Geological Survey Hydrologic Laboratory, Denver, CO. 2 In milliequivalents per 100 grams.

\section{Carbonate Content}

Carbonate content and cation-exchange capacity were analyzed to help determine their influence on potential solute movement. The carbonate content of the samples ranges from 0 to 36.1 percent in the EWR samples (table 5), and as high as 62.9 percent in the pit 15 samples (fig. 6). A greater carbonate content in sample EWR-1-2 than in EWR-1-1 may be explained by several means. Depth at which carbonate accumulates is indicated by the amount of precipitation and thickness of the sedimentary material or rate of aggradation of the surface (Jenny and Leonard, 1934; Arkley, 1963). If the 
surface is stable and sufficient moisture is applied to saturate the sedimentary material at a level $0.3 \mathrm{~m}$ above the sediment-basalt contact, the evaporation of this water will lead to the precipitation of calcite. This mechanism may also account for the observed increase in smectite in samples EWR $-1-1$ and EWR-1-2.

\section{Cation-Exchange Capacity}

The cation-exchange capacity measured in the samples (table 5) is notably higher in samples EWR-1-4 and EWR-1-3 than in samples EWR-1-2 and EWR-1-1 and is largely a function of the dominance of I/S (illite/smectite) clays, a high percentage of smectite, and lower carbonate contents in the samples with the high exchange capacity. The exchange capacity may be reduced if carbonate cements expandable clay particles together and limits solution contact.

Sediment-Basalt Relations

Sedimentary material accumulates by fluvial or eolian processes in cracks and depressions in the basalt surface. The longer the surface is exposed without interruption from another basalt flow, and as long as a source of sedimentary material is available, the thickness of the surficial sedimentary deposit will continue to increase. In areas where the basalt surface is exposed, alterations of the basalt minerals increases with the length of exposure.

Open fractures in the basalt may extend upward to the flow surface. During the aggradation of surface sedimentary material onto a new basalt surface, eolian dust and fluvial sediment accumulate in small depressions. This material, much of it clay-sized, may be suspended in water that accumulates in depressions and may be transported down into the open fracture. As the water evaporates, or is absorbed by dehydrated sediments, it will deposit the clay particles as layers on the fracture surface or in 
open vesicles. A series of minor infiltration events can lead to a series of thin clay layers in the fracture or vesicle.

Flooding occurs occasionally in the RWMC area due to locally heavy precipitation or rapid thaw of the snowpack and will carry coarser (silt and sand sized) material into the fractures. Particles of this size which have been transported from the surface have been observed in thin sections of cores obtained from the RWMC (Rightmire and Lewis, 1987).

Compaction and sediment infilling around buried waste leads to depressions, open cracks, or collapse features on the land surface. These features provided additional channels for water movement. While there is no evidence of recent sediment movement beneath the SDA of a significant magnitude, conditions for such have been present and could account for movement of sediment from beneath the SDA to some deeper level within the unsaturated zone.

Both open, unlined, and sediment-filled fractures were observed as shallow as $1 \mathrm{~m}$ below the contact between the surficial sediment and basalt (well 76-4; Rightmire and Lewis, 1987). Most of the fractures observed were filled with slightly to strongly calcareous, light tan fine silt and clay. Some vesicles show stalactitic growth of calcium carbonate with no geopetal clay present. This suggests that dissolved $\mathrm{Ca}^{2+}$ and $\mathrm{HCO}_{3}^{-}$were moving through the intergranular porosity into the vesicles before evaporation of water or outgassing $\mathrm{CO}_{2}$ caused precipitation of $\mathrm{CaCO}_{3}$.

Lined portions of fractures contain a thickness of as much as $1 \mathrm{~cm}$ of sediment. It is impossible to determine the pre-drilling width of the open fractures because the basalt fracture is not cemented. The thickness of the material filling the fractures, however, give a minimum dimension. Some horizontal fractures have $\mathrm{CaCO}_{3}$ precipitated on the upper surface and clay particles deposited on lower surface. Channels present within fracture lining sediment at $3.60 \mathrm{~m}$ may be due to root tubes or worm burrows.

Some coarse silt and sand were observed filling clay-lined fractures immediately above a sedimentary interbed encountered at a depth of $9 \mathrm{~m}$. On 
the basis of core examination, the section between the base of surficial sedimentary material and the top of the first sedimentary interbed is probably a single flow, and the sand present in these fractures terminated at the top of the interbed indicating that sand moved down vertical fractures to the top of the $9-m$ interval.

\section{Interflow Sedimentary Beds}

Three interflow sedimentary beds have been identified at the RWMC and were designated earlier as the $9-\mathrm{m}$, the $34-\mathrm{m}$, and the 73-m beds. The 73-m bed was observed in all wells drilled within the RWMC. Burgus and Maestas (1976) report a bed at about $9-\mathrm{m}$ in we1ls $96 \mathrm{~A}$ and $96 \mathrm{~B}$ in addition to the 34-m and 73-m beds. The tops, bottoms, and thicknesses of the interflow beds are given in table 1 . Figure 7 shows the thickness and lateral distribution of the interflow sedimentary beds encountered during the drilling of wells in the 1976-77 and previous drilling programs at the RWMC (see figures 1 and 3 for well locations). It also shows that the $34-\mathrm{m}$ bed pinches out under the central part of the SDA.

\section{Stratigraphy}

The 9-m sedimentary interbed is thickest to the northwest and thins progressively to the southeast (fig. 7A). Where present it consists of as much as $2.13 \mathrm{~m}$ of reddish brown to dark brown silty clay. Samples from wells 76-3 and 76-4 yield an organic-rich paleosol. Well 76-5 contains approximately $4.6 \mathrm{~cm}$ of baked clay (color $5 \mathrm{YR} 5 / 6$ ) overlain by a cinder zone. Organic material observed underlying shallow lava flows was probably introduced by infiltrating waters. The organic-rich 9-m sedimentary layer underlying the thin lava flow at $7.38 \mathrm{~m}$ in well $76-3$ reinforces this possibility.

The reddish-brown to yellowish-brown colors throughout the "non-soil" parts of the 9 -m sedimentary layer suggest several possibilities for their origin. In all but one well (77-2), red coloring is indicative of oxidation of ferrous iron derived from iron silicate minerals that compose up to 

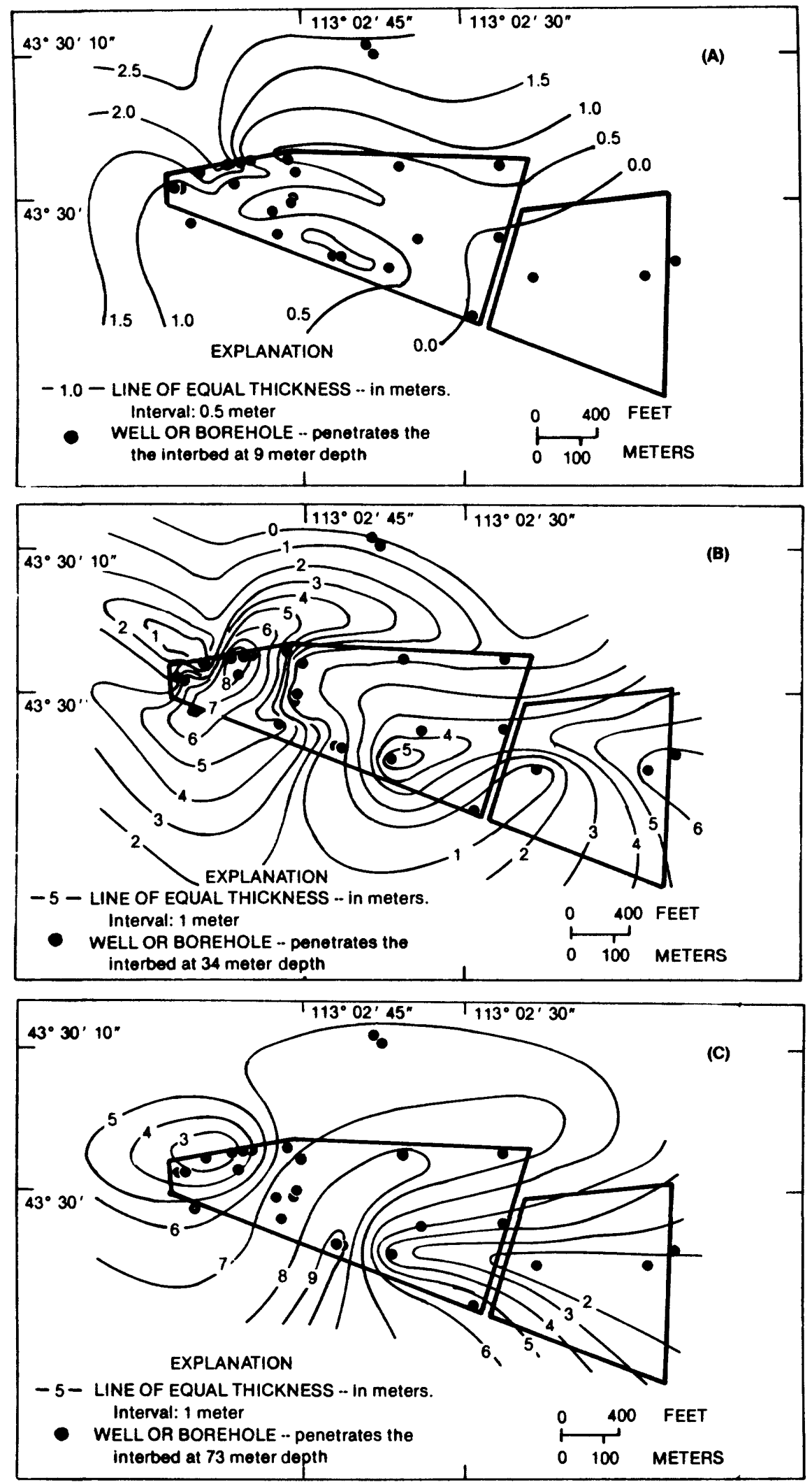

Figure 7.--Thickness and lateral extent of sedimentary interflow beds at the Radioactive Waste Management Complex: A) interbed at 9-m depth;

B) interbed at 34-m depth; and C) interbed at 73-m depth. 
20 percent of bulk mineralogy. Sedimentary material with light brown color $(5 \mathrm{Y} 6 / 2)$ is observed at the base of the $9-\mathrm{m}$ bed in well $76-4 \mathrm{~A}$. The top portion of the sedimentary bed in that well is a dark reddish-brown color (10 YR 4/2). This coloration results from dehydration and oxidation of iron-rich minerals by heat from the overlying lava flows (Beukenkamp and Sevink, 1971). The coloration of the organic soil zones are presumably less affected because much of their iron has been removed during soil development.

A second possibility for the development of red sediment is oxidation of the ferrous iron to ferric iron in an historic oxygenated soil atmosphere where it is released during the weathering of olivine and augite. In an environment with a $\mathrm{P}_{\mathrm{O}_{2}}$ of about $10^{-0.7}$ and a $\mathrm{P}_{\mathrm{CO}_{2}}$ of about $10^{-3.0}$ (conditions observed in soil gases at the INEL) ferric oxyhydroxide would be expected to precipitate almost immediately. However, this explanation for the coloration makes it more difficult to explain the lack of color alteration of sedimentary material observed in wells 77-2 and portions of $76-4 \mathrm{~A}$.

No reddish-brown sedimentary material is found filling fractures beneath the $9-m$ interbed. If the sediment had been altered as it lay exposed on the ground surface, at least some of it would have been transported to some depth within the fractures in the same manner as the material from the previously discussed surficial sedimentary deposit. Since the coring sampled such a small volume of rock, it is possible that this oxidized material is present but was not observed. However, since reddishbrown material exists in most of the other sedimentary interbeds and none is observed beneath them, the oxidized material was formed as the sedimentary beds are isolated from the surface environment by an overriding basalt flow.

The basalt immediately underlying the $9-\mathrm{m}$ interbed contains $\mathrm{CaCO}_{3}$ stalactitic structures in vesicles and on the upper surface of diagonal fractures. The $\mathrm{CaCO}_{3}$ content of the sediment material decreases with depth beneath the bottom of the $9-\mathrm{m}$ interbed. Most of the carbonate is 
concentrated in the uppermost $5 \mathrm{~m}$ of the basalt underlying the 9 -m interbed but some $\mathrm{CaCO}_{3}$ is observed almost to the top of the $34-\mathrm{m}$ interbed.

Fracture filling and lining material consists of a range of particle sizes from clay to fine sand. The same evidence for episodic sedimentation that was observed in the basalt above the $9-\mathrm{m}$ interbed is seen at a greater depth. Not all of the fractures are completely filled. Open fractures were observed at depths in excess of $19 \mathrm{~m}$ in wells 77-2, 76-5, 76-4, and 76-2.

The 9-m sedimentary interbed was not encountered, and its relative position in the core could not be determined in well 76-6. This suggests that the surface on which that sedimentary interbed developed was not exposed for a sufficient length of time to permit alteration or chemical precipitation on the surface of the exposed basalt flow on which that sedimentary unit was deposited. This conclusion is supported by the overall lack of thickness of that sedimentary unit in the RWMC.

The 34-m sedimentary interbed is generally thickest to the west and thins progressively to both the north and south (fig. 7B). It is $7.28-\mathrm{m}$ and 4.11-m thick respectively, in wells $76-3$ and 76-5. All samples from wells other than 76-3 and 76-5 exhibit 5 YR and 10 YR colors throughout the thin interbed section. Well 76-3 exhibits 5 YR and 10 YR color through $1.13 \mathrm{~m}$, it becomes $5 \mathrm{Y} 5 / 2$, a light olive gray, below that depth. We11 76-5 sediments exhibit evidence of coloration at least $2.53 \mathrm{~m}$ into the bed. The bottom sample is 5 Y $6 / 3$.

The top of the $34-\mathrm{m}$ interbed at $29.20 \mathrm{~m}$ in well $76-3$ contains a dark brown organic-rich (?) soil horizon. This sedimentary deposit contains basalt pebbles, some coated with a laminar crust of calcium carbonate as in caliche deposits, and completely encrusts several included basalt cobbles. Some underlying vesicles are filled with reddish-brown material, suggesting that this infilling was emplaced prior to formation of the caliche. The caliche contains small aggregates of opaline silica.

The 34-m sedimentary interbed was not encountered in we11s $76-1$ and 76-2. However, deposition of $\mathrm{CaCO}_{3}$, amorphous silica, and some suggested 
Ca-smectite mineral phases in vesicles immediately below a flow contact (figs. 8 and 9) represents the exposed basalt surface at those locations and suggests that the locations of 76-1 and 76-2 were topographic highs on the pre-deposition surface. The presence of the caliche in the 34-m sedimentary interbed in wells $76-4$ and 76-4A suggests that these we11s were in a topographic low during the deposition of this interbed.

The 73-m interflow sedimentary bed is thickest near the center of and south of the RWMC (fig. 7C). In some wells $(76-2,76-5$, and 76-6) it is overlain by basalts with clay-lined and clay-filled fractures. This 1 ining material moved down from the exposed surface, through the fractures in the basalt to a depth of $3 \mathrm{~m}$ above the top of the interflow sedimentary bed. The 73-m interbed material exhibits iron-oxyhydroxide coloration throughout its entire thickness, up to $9.75 \mathrm{~m}$, in every well which penetrated it. The continuity of the sedimentary interbed and the consistent elevation of its upper surface suggest that this bed extends over a larger area than has been mapped and suggests that, at the time of deposition, the area was once the flood plain of the Big Lost River. Particle size analyses of the 9-m, 34-m and $73-\mathrm{m}$, interbed samples indicate fluvial gravel content in excess of 50 percent in several samples.

\section{Particle-Size Distribution}

Particle-size analyses of the interflow sedimentary beds are shown in table 2, which includes data from both Barraclough, Robertson and Janzer (1976) and the current study. Sediment from the $34-\mathrm{m}$ sedimentary bed contains the coarsest particles. Sediment from the $9-\mathrm{m}$ bed is consistent with a trend towards more recent sedimentation in that it is finer grained. This may be due to a diminished supply of coarse-grained material, or to a lack of sufficient flow of water to transport coarser-grained material.

\section{Bulk Mineralogy}

Al1 of the samples reported by Barraclough, Robertson, and Janzer 


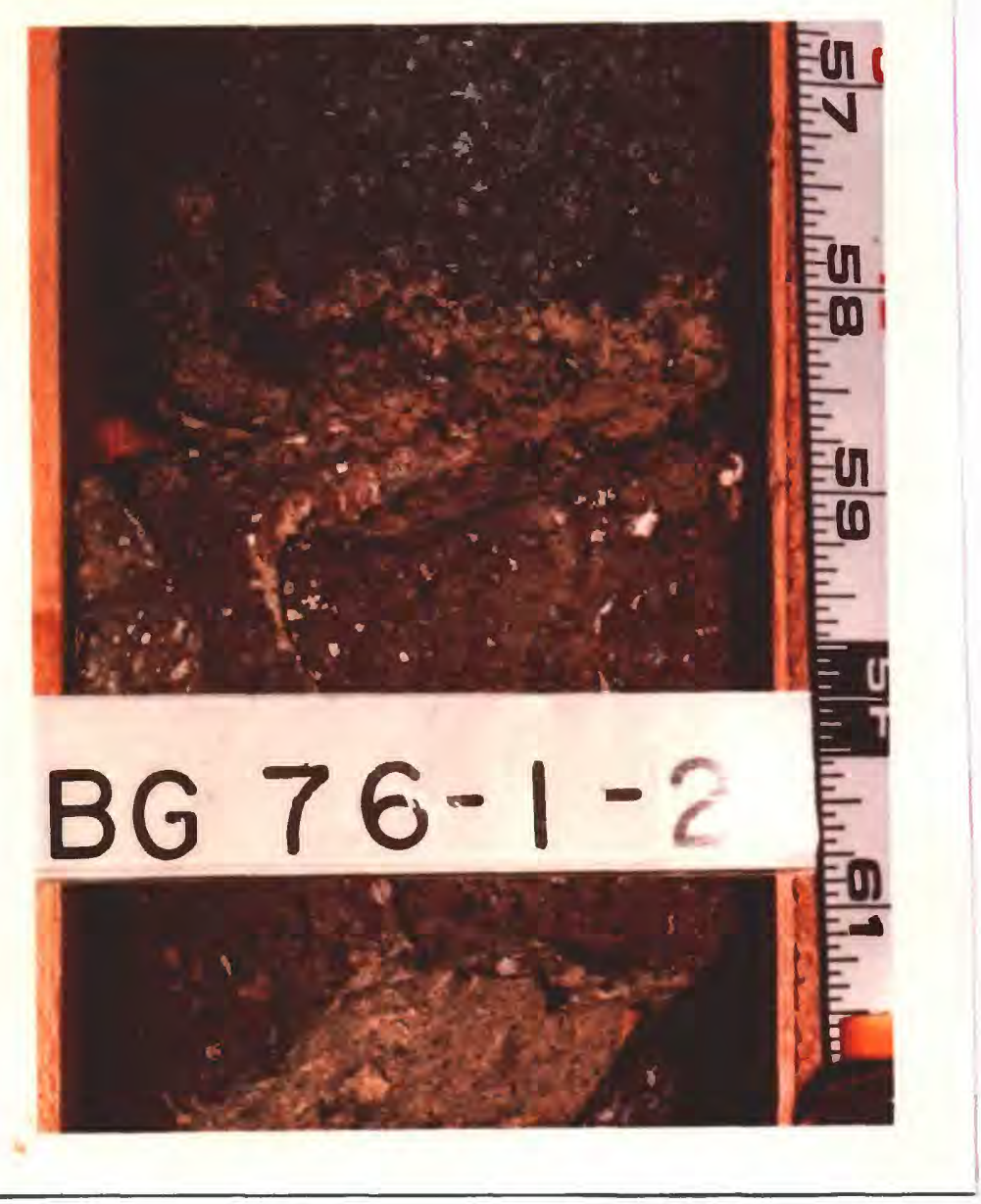

Figure 8.--Photograph of mineral deposits in vesicles immediately below a basalt flow contact in well 76-1, at a depth of 28.13 meters. 


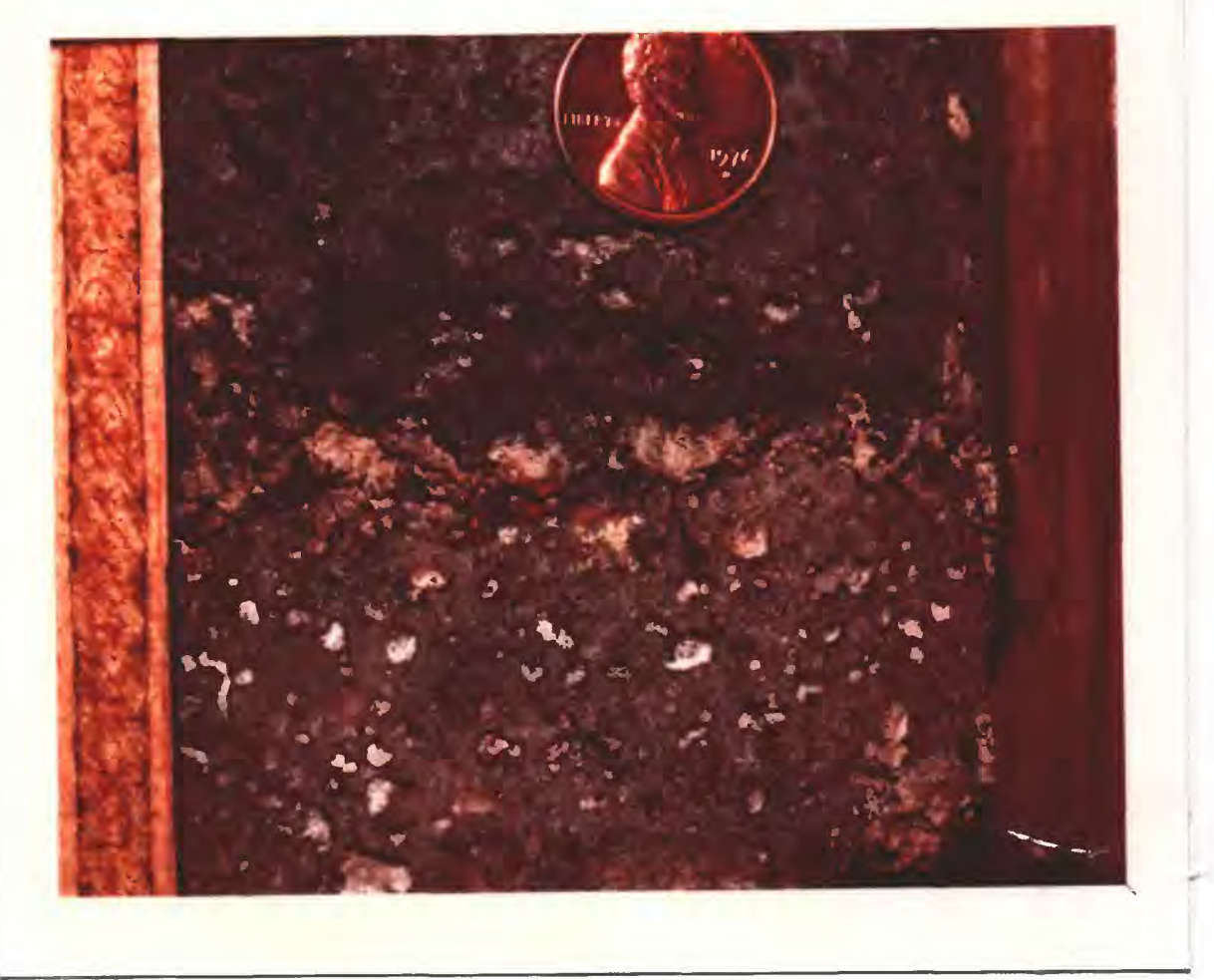

Figure 9.--Photograph of mineral deposits in vesicles immediately below a basalt flow contact in well 76-2, at a depth of 28.42 meters. 
(1976) contain quartz, plagioclase, clinopyroxene, and a mixed suite of clay minerals. This mineralogic composition was confirmed by subsequent analyses. The plagioclase is calcium-rich, with the composition of labradorite. The clinopyroxene mineral reported by Barraclough, Robertson, and Janzer (1976) is augite. On the basis of the mineralogy of the Snake River Plain basalts (Stout and Nicholls, 1977), augite is the only pyroxene mineral present in the basalts; and where weathered basalt is a major source of the sedimentary material, augite should be the dominant pyroxene mineral present.

The bulk mineralogy reported in Barraclough, Robertson, and Janzer (1976) only slightly resembles that of subsequent analyses for the same sedimentary intervals (table 6). However, few general trends are apparent. The amount of plagioclase (Barraclough, Robertson, and Janzer, 1976) and the plagioclase plus potassium feldspar are lower in the surficial material than in the sedimentary interbeds. This is also true for the percent augite. The percent clay minerals is higher in the surficial than in the deeper sedimentary beds.

Clay Mineralogy

Clay mineral analyses were done at the U.S. Geological Survey Hydrologic Laboratory, Denver, Colorado. This laboratory traditionally reports analyses of clays for the less than $4 \mu \mathrm{m}$ fraction. Because of this, these analyses may differ from the less than 2 or less than $1 \mu m$ analyses reported elsewhere.

The dominant clay minerals observed in the samples are illite and mixed-layer illite/smectite (I/S) (table 6). It is worth noting that the amount of both smectite and the amount of mixed layer, I/S, clays are significantly higher in the surficial sediment than in the sedimentary interbeds. The average amount of kaolinite is greater in the surficial. material than in any of the sedimentary interbeds. 


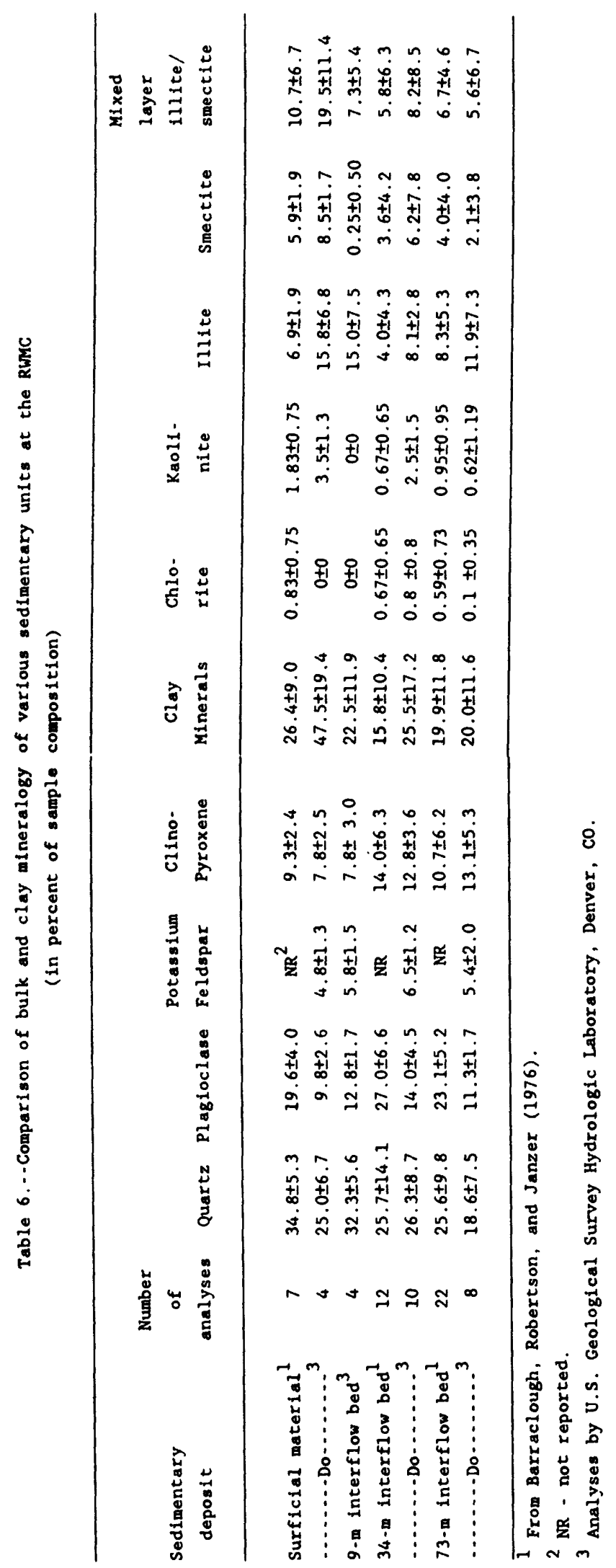


The clay mineral data suggest that, while all the sedimentary material was derived from the same lithology, the combination of presence of moisture and length of exposure of the surface must strongly influence the observed mineralogy. This may be due to concurrent alteration or to the influx of eolian dust which may migrate through the previously deposited alluvial or eolian material (Crone, 1975). It is generally considered that illite is detrital, but with fluctuation in the amount of smectite and mixed layer clays observed in this environment and the presence of altered potassium feldspars and the possibility of thermal alteration, it is conceivable that some formation of illite as well as smectite is occurring in place.

\section{Carbonate Content}

Mineralogic analyses reported in Barraclough, Robertson, and Janzer (1976) show calcite contents ranging from absent, for most of the samples, to 54 percent for others. High calcite content (greater than 10 percent) is reported in the $73-\mathrm{m}$ bed in wells $88,89,90$, and 96 ; in surficial material in wells 92 and 95; and from a vesicle at about $9 \mathrm{~m}$ in well 91.

Subsequent analyses show carbonate contents of up to 11.7 percent in the $34-\mathrm{m}$ interbed and up to 28.8 percent in the $73-\mathrm{m}$ interbed in we $1193 \mathrm{~A}$ and up to 2.4 percent in the $34 \mathrm{-m}$ and $73 \mathrm{-m}$ interbeds in we11 96B (Rightmire, 1984). The greatest amount of carbonate observed in the $34-\mathrm{m}$ interbed in we11 93A was present at the base.

\section{Cation Exchange Capacity}

The cation exchange capacities (CEC's) reported by Barraclough, Robertson, and Janzer (1976) range from $1.1 \mathrm{meq} / 100 \mathrm{~g}$ for one sample from the $34-\mathrm{m}$ interbed in well 88 to $45 \mathrm{meq} / 100 \mathrm{~g}$ for a sample from the $34-\mathrm{m}$ interbed in well 96. These samples contain from zero to 34 percent identifiable expandable layer clay (I/S) respectively. No determination of the percent of expandable layers in those clays is given. 
Later analyses show a CEC range of $0.9 \mathrm{meq} / 100 \mathrm{~g}$ for one $9-\mathrm{m}$ interbed sample in well $96 \mathrm{~B}$ to $36 \mathrm{meq} / 100 \mathrm{~g}$ for two samples, one at the base of the $73-\mathrm{m}$ interbed and one fracture filling above the 73-m interbed (Rightmire, 1984). The low CEC sample contains total clay minerals of 5 percent, all of which is illite. The high CEC samples range from approximately 9 to 33 percent expandable layer clays, mixed-layer clays, and smectite, respectively. Assuming that half of the layers in the mixed-layer clay are expandable, the cation exchange capacity increases as the percentage of expandable layers in the clay increases (Rightmire, 1984).

Well 76-3 Core Analyses

Sedimentary core samples collected from well 76-3 were selected for additional mineralogic and stable isotope analyses. Well 76-3 was selected because it contained core material from all three sedimentary interbeds and sufficient fracture filling material to be submitted for several different analytical procedures. Core sample descriptions are listed in Rightmire and Lewis (1987).

Bulk mineralogic analyses by $X$-ray diffraction were done on 12 samples to; 1) determine the mineralogy of the bulk sample prior to separation of the less than $1 \mu \mathrm{m}$ clay fraction, and 2) compare these analyses with those done previously. The analyses indicate possible parent material for in place alteration of sedimentary material to clay minerals. The results of the bulk mineralogic analyses are given in table 7 . It should be noted that several samples high in iron were analyzed both before and after removal of iron by the dithionate-citrate method. This procedure results in significant changes (up to 9 percent) in the percentages of layered silicates (clay minerals) in the four samples so treated.

Quartz and plagioclase feldspar were the dominant minerals, ranging from 24 to 60 percent and 11 to 57 percent, respectively. These two minerals were most likely derived from the mountains to the west and transported to the area by fluvial and eolian processes. Layer silicates ranged in abundance from less than one percent to 46 percent of the bulk 
Table 7.-.Semi-quantitative bulk-sediment analyses of selected samples from wel1 $76-3$ (in percent of bulk sample) ${ }^{1}$

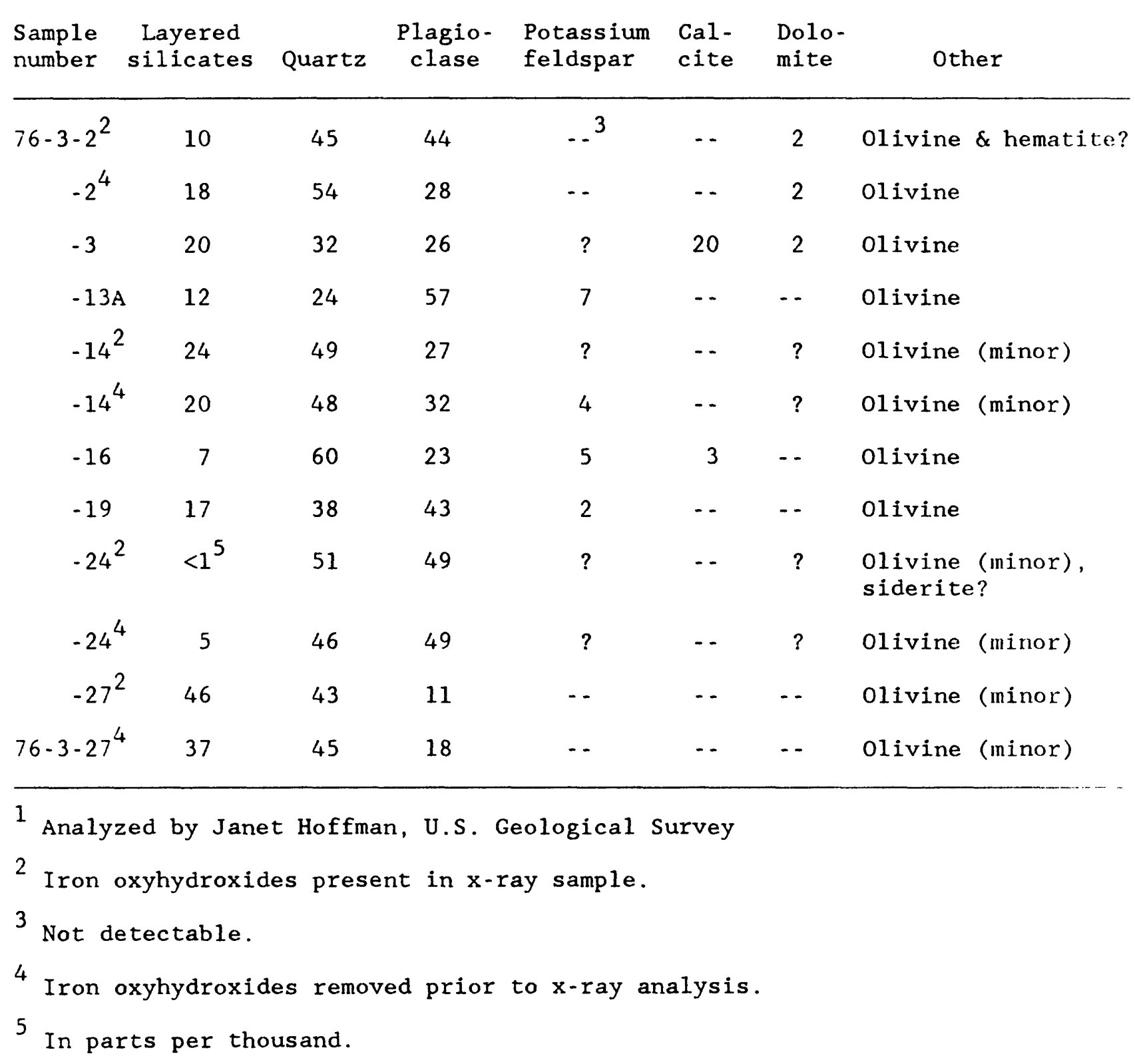


sample. Potassium feldspar, calcite, and dolomite were identified in various samples. Traces of olivine, hematite, and siderite also were identified. No pyroxene minerals were identified in these samples.

Sample 76-3-3 was collected from a fracture immediately below the 9-m interflow bed and 76-3-14 was collected from within the 34-m interbed. The dolomite identified in samples 76-3-2 and 76-3-3 is believed detrital.

Iron minerals were present in various degrees in samples from all three sedimentary beds. The only iron minerals identified by X-ray diffraction were hematite (?) in sample 76-3-2 and siderite (?) in sample 76-3-24. This suggested that the iron oxyhydroxides were amorphous to cryptocrystalline and probably influenced the analysis of the clay-size fraction. Olivine present is weathering to residual iron oxyhydroxides.

The less than $1 \mu \mathrm{m}$ size fractions of a suite of samples, were separated and analyzed by X-ray diffraction in an attempt to identify the specific clay mineral phases and to determine their abundance.

A brief discussion of clay mineralogy will give background information as to the utility of these studies prior to the discussion of the observations. Clay minerals are common alteration products of many silicate and aluminosilicate minerals. The end-product clay mineral formed is determined primarily by the type of parent minerals and the local hydrogeochemical environment.

The presence of authigenic kaolinite suggests an environment characterized by the following:

(a) high $\mathrm{Al} / \mathrm{Si}$ ratio;

(b) $\mathrm{pH}$ less than 7; and

(c) practically complete removal of major aqueous cations $\left(\mathrm{Na}^{+}, \mathrm{K}^{+}, \mathrm{Ca}^{2+}\right.$, and $\left.\mathrm{Mg}^{2+}\right)$.

Geologically favorable terrains for kaolinite formation include those with an aluminum-rich parent material, abundant moisture to provide leaching conditions, and a pH of less than 7. Since silica is more soluble than 
alumina at $\mathrm{pH}$ less than 7, potassium and sodium feldspars would probably lose $\mathrm{Si}$ (therefore be enriched in $\mathrm{Al}$ ) by solution more readily than calcium feldspars. Granitic rocks would be more likely than mafic or calciummagnesium silicate rocks to kaolinize.

Smectite is composed of two tetrahedral silica layers surrounding an octahedral alumina layer (2:1 clay). Because of the layered structure and the structural charge distribution, smectite can exhibit significant cation exchange capacity. This is due to a charge imbalance caused by the substitution of a lower valence ion in either the tetrahedral layer for silicon or in the octahedral layer for aluminum. The presence of authigenic smectite suggests the following hydrogeochemical environment:

(a) high $\mathrm{Si} / \mathrm{Al}$ ratio;

(b) relative abundance of the major aqueous cations $\left(\mathrm{Mg}^{2+}, \mathrm{Fe}^{2+}, \mathrm{Ca}^{2+}\right.$, $\mathrm{Na}^{+}$); and

(c) neutral or alkaline $\mathrm{pH}$.

These conditions suggest that a semiarid environment, where precipitation is less than potential evaporation, is a likely area for smectites to form. Hydrolysis occurs with the infiltration of water. The solution will concentrate and permit combination of $\mathrm{SiO}_{2}-\mathrm{Al}_{2} \mathrm{O}_{3}$ and cations to form cryptocrystalline silicates and perhaps smectite during evaporation.

Illite is a $2: 1$ clay mineral with potassium ( $\mathrm{K}^{+}$) filling the exchangeable cation sites. Hydrated $\mathrm{K}^{+}$ion has the ideal radius and surface charge density to be fixed within the $2: 1$ clay structure. Illite is commonly considered to be of detrital origin in soils but it can also be formed in place. It is usually derived from the weathering of mica. It is the dominant clay mineral found in limestone and shales.

An additional clay mineral phase, or series of phases, must be considered here. These are called interstratified or mixed-layer clays. They are made up of some combination of $2: 1$ clays such as illite/smectite, and will have properties somewhat between those of the end members of which they are composed. A mixed layer illite/smectite will have exchange 
capacity proportional to the percentage of expandable smectite layers present in its structure.

There is an exchange preference in the 2:1 clays which contain exchangeable cations in a fresh ground-water system. That preference for monovalent cations generally is:

$$
\mathrm{Li}^{+}<\mathrm{Na}^{+}<\mathrm{K}^{+}<\mathrm{Rb}^{+}<\mathrm{Cs}^{+} \text {, }
$$

for divalent ions the preference is:

$$
\mathrm{Mg}^{2+}<\mathrm{Ca}^{2+}<\mathrm{Sr}^{2+}<\mathrm{Ba}^{2+} \text {. }
$$

Hydrated bivalent cations will enter exchange sites in preference to monovalent cations. $\mathrm{Ca}^{2+}$ is commonly the dominant exchangeable cation on exchange sites of soil clay minerals that are in contact with dilute ground water.

Thirty-one (31) samples of clay-size (less than $1 \mu \mathrm{m}$ ) material were separated for clay mineral analyses (table 8). Two of the samples (76-3-22b and 76-3-23) contained too little clay size material for X-ray analysis. The remaining 29 samples were treated in the following manner and $X$-rayed. Untreated oriented samples were analyzed, as were glycolated samples. The glycolated samples were then heated to 350-400 oC for one-half hour and reanalyzed. This procedure permitted the definition of illite, kaolinite, smectite, mixed layer (illite/smectite), and possibly chlorite.

Illite and/or mixed-layer illite/smectite (I/S) are the dominant clay mineral species in all samples studied (table 8 ). In a few instances where it was impossible to determine percentages of individual constituents because of particle orientation, presence of iron, or very little clay, illite and $I / S$ are still identified as the dominant species. Illite content ranges from 9.9 to 100 percent while I/S ranges from absent to 75.5 percent (table 8 ). The percentage of smectite, in the mixed layer component, ranges from less than 20 to a high of about 60 percent. The nonexpandable components were determined by the techniques of Schultz (1964). The percentage of smectite in the mixed-layer clays was determined utilizing techniques of Reynolds and Hower (1970). 
Table 8.--Clay mineral content of sedimentary samples from well 76-3 (in percent of clay minerals present) ${ }^{1}$

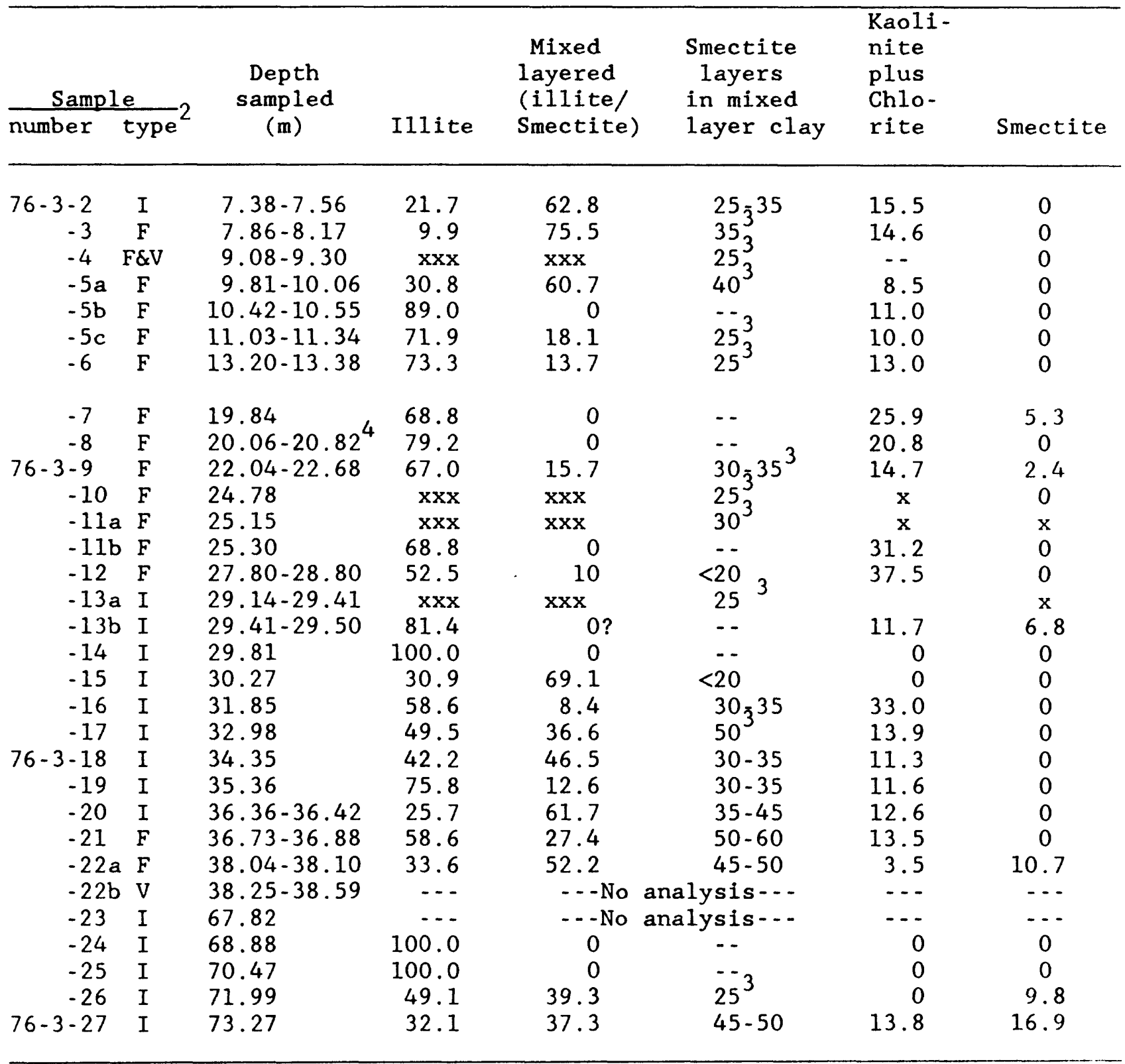

1 Where percentages could not be determined; $\mathrm{xxx}$ is dominant amount, $\mathrm{xx}$ is mineral present, and $x$ is present but minor amount.

2 F-fracture-fill sample, I-interbed-flow sample, and V-vesicle sample.

3 Approximate value.

4 Sample collected primarily from 20.06 to $20.15 \mathrm{~m}$. 
Very little discrete smectite was identified; however, the differentiation of discrete smectite from mixed layer I/S is difficult. The fact that most of the X-ray patterns show collapse to 10 Ao peaks on heating suggests that smectite is the dominant inter-layer clay with the illite. The smectite present is predominantly calcium smectite.

Three samples containing 100 percent illite and one sample containing an excess of 80 percent illite and no I/S are found in the upper meter of the $34-\mathrm{m}$ and the $73-\mathrm{m}$ interbeds.

\title{
REGIONAL HYDROLOGY
}

\author{
SURFACE WATER
}

The study area is located in a semiarid volcanic terrain that, under ordinary climatic conditions, contains only minor amounts of surface water. The Big Lost River (which drains parts of the Lost River and the Lemhi Ranges) and Birch Creek (which drains parts of the Lemhi and the Beaverhead Ranges) is utilized for irrigation prior to reaching the site. Prior to major irrigation in the tributary valleys these streams drained into the Lost River Sinks and Birch Creek Playa, closed basins on the north end of the INEL (see fig. 2), during times of high flow. Water impounded in these playas either infiltrated or evaporated.

Infiltration and, potentially, ground-water recharge occurs along the channel of the Big Lost River when water is present. When flow exceeds 14 cubic meters per second $\left(\mathrm{m}^{3} / \mathrm{s}\right)$ the excess flow is diverted into a series of natural and man-made impoundment areas at the southwest end of the site (see figure 2). These diversion areas have been shown to be a source of recharge to the Snake River Plain aquifer (Barraclough, Robertson and Janzer, 1976).

Lava flows form many small closed topographic basins in which water accumulates at times of high precipitation or snowmelt. This water may then evaporate or infiltrate into the surficial sediment. It is likely that the only significant infiltration that takes place occurs as the snowpack is 
melting in the early spring. Most of the thunderstorms, which are the second major source of precipitation, occur in the early summer months and contribute only minor amounts of infiltration.

\section{GROUND WATER}

The eastern Snake River Plain overlies the largest potable water aquifer in Idaho. The Snake River Plain aquifer is a sequence of basalt flows and interbedded sedimentary units. In general the greatest hydraulic conductivity is observed at basalt flow contacts where irregular fractures, cinder zones, and surface irregularities are prevalent (Robertson, Schoen, and Barraclough, 1974).

Porosity and hydraulic conductivity values in the basalts range from very low in dense portions of basalt flows to extremely high in cinder or scoria zones and along interflow contacts. Vertical hydraulic conductivity of individual basalt flow layers, however, even in the dense basalts, is greatly enhanced by the presence of fractures that penetrate the basalt's flows. However, these fractures generally do not extend through more than one flow. Fractures in basalts may differ in aperture from several micrometers to several meters for large pressure ridges. Open, unfilled fractures have been observed as deep as $54 \mathrm{~m}$ in one corehole at the RWMC. These fractures were lined with clay on both sides but had been open prior to the cementing of an adjacent well. Fracture frequency and aperture are generally much greater near the flow surfaces (especially the top surface), which can greatly enhance horizontal hydraulic conductivity in the waterflow zones. Vesicular layers occur near the top and bottom of basalt flows. The vesicles are commonly not interconnected and, although the porosity of these units may be high, the hydraulic conductivity may be low.

Most evidence suggests that the average effective thickness of the Snake River Plain aquifer in the vicinity of the INEL is approximately $300 \mathrm{~m}$. The upper $80 \mathrm{~m}$ of the saturated zone appears to be the most transmissive part of the aquifer (Robertson, Schoen, and Barraclough, 1974). 
Water enters the regional aquifer from the west, north, and east. Most of the inflow occurs as underflow from alluvial-filled valleys along tributaries of the Snake River on the east side of the plain, from mountain ranges on the north, and from the alluvial valleys of Birch Creek, Little Lost River, and Big Lost River on the west. Little recharge occurs through the surface of the plain except for flow in the channel of the Big Lost River, its diversion areas, and some irrigation return flow.

The configuration of the water table indicates that water in the Snake River Plain aquifer moves generally from the northeast to southwest, approximately parallel to the long axis of the plain, discharging at Thousand Springs near Hagerman, Idaho, along the Snake River. Average flow rates, while meaningful only as approximations of rates of water movement, show a range between 1.5 and 6-m per day (Robertson, Schoen, and Barraclough, 1974).

\section{Radioactive Waste Management Complex}

The water table beneath the RWMC is at a depth of approximately $175 \mathrm{~m}$. A U.S. Geological Survey study (Barraclough, Robertson, and Janzer, 1976) reported the drilling of four wells to the water table in the vicinity of the RWMC (see figure 1 for well locations). These wells (numbers 87, 88, 89, and 90) located north, south, west, and east of the RWMC were drilled to depths of $195.1 \mathrm{~m}, 193.5 \mathrm{~m}, 196.9 \mathrm{~m}$, and $190.8 \mathrm{~m}$, respectively.

The altitude of the water table in the vicinity of the RWMC indicates that there is recharge to the aquifer in the vicinity of the diversion area and from the Big Lost River. The development of a slight ground-water mound beneath the diversion area follows periods of high river flow in which surface water has been diverted (Barraclough, Robertson, and Janzer, 1976). The hydrograph of nearby well 89 , indicates a lagtime of about six months from the time of surface water diversion into the area to a correlative rise in the water table. 
Fluctuations in the position of the regional water table occur seasonally, with periods of recharge correlated to spring runoff, and periods of withdrawal correlated to major pumping for irrigation purposes. Droughts, like that which occurred from 1977 through 1980, may lead to a 0.6 to $1.8 \mathrm{~m}$ annual decline in the water level beneath selective parts of the INEL (Lewis and Jensen, 1985). During this period, no water was introduced into the diversion area because flow in the Big Lost River was minimal or nonexistent at the point of diversion.

\section{Perched Ground Water}

Perched ground water has been identified beneath the RWMC at several depths. Figure 10 shows depths at which perched water has been reported either in driller's logs, as saturated core or standing water in the bottom of the drill hole. There is a predominance of observations in the northwest quadrant of the SDA. This may be due to a major drilling effort in this area, but may also be due to the proximity of this area to the diversion ponds.

Perched water has been identified at three depth intervals in the area. These intervals correspond roughly to the depth of the major sedimentary interbeds in the basalt. Standing water is located in well 92 at a depth of about $65 \mathrm{~m}$ and in we11 77-2 at about $26 \mathrm{~m}$. Water-saturated sedimentary material was observed in core from well 76-1 at $10 \mathrm{~m}$. These depths correspond approximately to the tops of sedimentary beds at depths of 73 , 34 , and $9 \mathrm{~m}$, respectively, in those wells indicating that the interbedded sediments are saturated.

When vertical flow is retarded and a perched mound starts to develop, the potential for lateral water movement is enhanced. The diversion ponds overlie areas which once were probably the channel and flood plain of the Big Lost River. It is likely that the interflow sedimentary beds are thicker along the channels, increasing the possibility that the sedinents are capable of retarding vertical flow. Perched water would then be 
expected to move laterally before moving vertically to the aquifer. Thus, it is possible that the perched water beneath the RWMC is derived largely from the diversion ponds and/or the Big Lost River channel with only a minor contribution of moisture from vertical water movement of atmospheric precipitation through the RWMC.

\section{Unsaturated Zone}

The thickness of the unsaturated zone, discounting zones of perched water, ranges from about $175 \mathrm{~m}$ in well 90 on the east side of the RWMC to about $180 \mathrm{~m}$ in well 89 on the west. Most of this difference is attributable to topography.

The recurring presence of a ground-water mound beneath the diversion area indicates that most of the water moves vertically to the water table. The lateral continuity of some of the sedimentary interbeds, particularly the $73-\mathrm{m}$ interflow bed, suggests that water recharged from the diversion ponds could also move to the east the approximately $1.7 \mathrm{~km}$ necessary for it to be present beneath the western edge of the RWMC. As previously noted, water was observed at $10-\mathrm{m}, 26.5-\mathrm{m}$, and $65-\mathrm{m}$ depths on the northwest side of the RWMC, and it is conceivable that lateral migration is a stepwise depth progression from the $10-\mathrm{m}$, to the $26-\mathrm{m}$, to the $65-\mathrm{m}$ depth perched-water zones. This could lead to significant lateral movement of water from beneath the ponds.

Vertical water movement through the lava-sedimentary sequence is largely controlled by hydraulic conductivity in fractures in the lava flows; and by lower hydraulic conductivity in some of the finer material in the interbeds. Barraclough, Robertson, and Janzer (1976) report a range of values of vertical hydraulic conductivity of selected interbedded sedimentary units at the RWMC from $1.6 \times 10^{-7}$ to $3.0 \mathrm{~m} /$ day, and the porosity may range up to 53 percent. An approximate vertical hydraulic conductivity value for the sedimentary units in the sequence may be from about $10^{-2}$ to $10^{-3} \mathrm{~m} / \mathrm{day}$. Horizontal hydraulic conductivity in some of the cinder zones may be up to 5 or $6 \mathrm{~m} /$ day. 


\section{GEOCHEMISTRY}

\section{ATMOSPHERIC PRECIPITATION}

Samples of precipitation events greater than $1 \mathrm{~mm}$ were collected from August 25, 1976, to December 9, 1977 at 1104 and 1116 East 21st street, Idaho Falls, Idaho (adjacent residences). Amounts of precipitation sampled ranged from $0.2 \mathrm{~mm}$ collected on July 27, 1977 to $21.7 \mathrm{~mm}$ collected on October 3, 1976. Several storms of several days duration yielded in excess of $10 \mathrm{~mm}$ of precipitation. Monthly composite precipitation samples were collected at the Central Facilities Area by the National Oceanic \& Atmospheric Administration (NOAA) for December 1977 through February 1978. Selected samples have been analyzed for deuterium and oxygen-18. Analytical techniques were detailed by Rightmire and Lewis (1987).

Snow samples were collected at three locations adjacent to U.S. Geological Survey wells 22 and 83 , and site 9 (see figure 11 for we 11 locations) on the INEL on February 2, 1978 for chemical analysis and to determine the water content.

Samples were collected during the 1976-77 water year when drought conditions existed in the northwest. While the total precipitation for calendar year 1977 was $200.4 \mathrm{~mm}$ and was within ten percent of the Idaho Falls long-term annual average of $220.2 \mathrm{~mm}$, most of the moisture fell as small summer showers and very little accumulated as snowpack, which usually supplies the bulk of the moisture infiltrated into the shallow subsurface. The winter of 1977-78 developed a snowpack which contained between 50 and $60 \mathrm{~mm}$ of water. During 1978, every month through May produced moisture in excess of $25 \mathrm{~mm}$. The area went from drought conditions during summer 1976 through November 1977 to conditions of above normal moisture for the winter of 1977-78. 


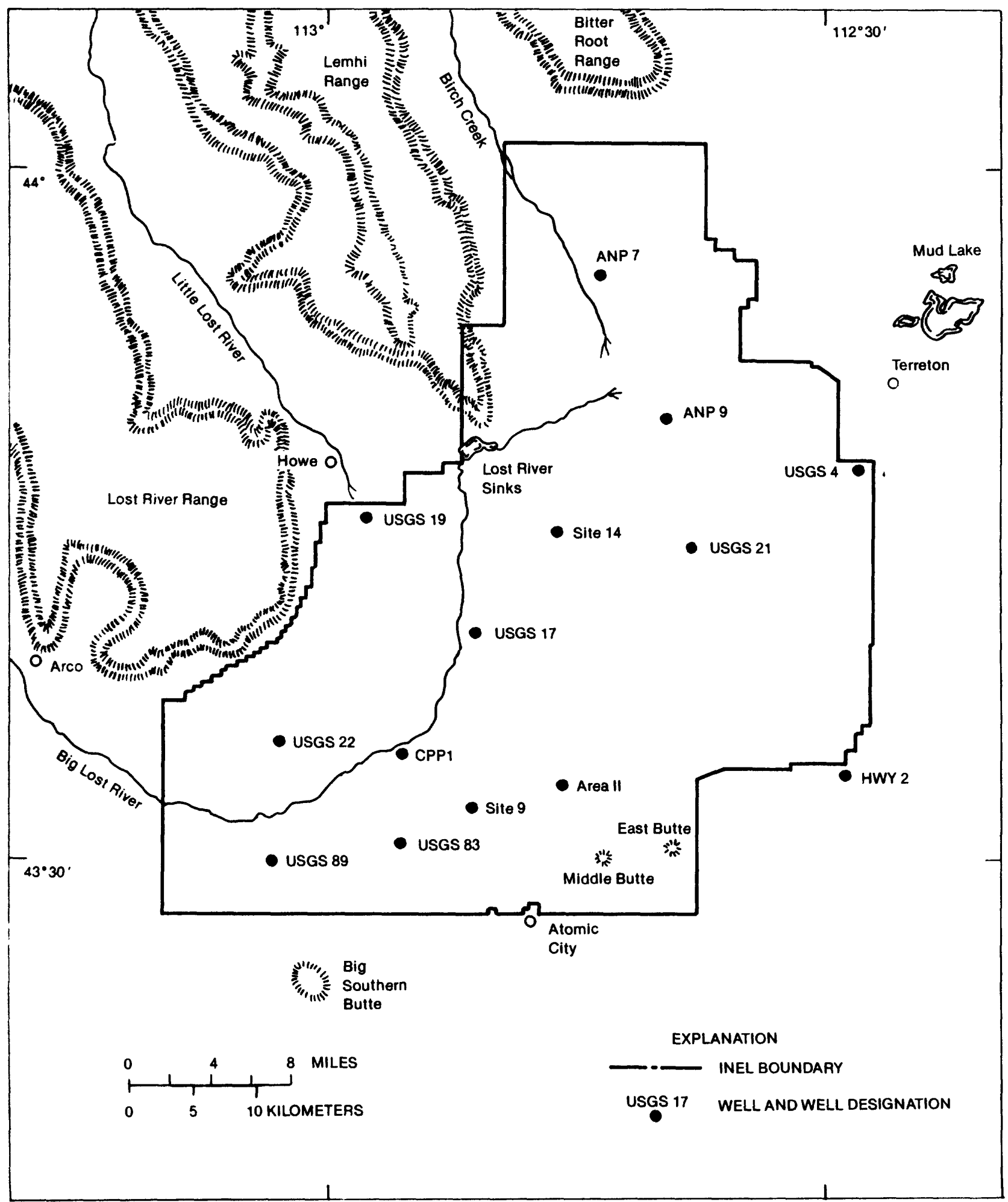

Figure 11.--Location of selected production and observation wells at the Idaho National Engineering Laboratory. 
Snowpack samples collected at three locations on the INEL, which are considered representative of the principal source of infiltrating water on the surface of the Snake River Plain, yielded water amounts as shown below:

$\begin{array}{ccc}\text { Sampling location } & \text { Depth of Snow }(\mathrm{mm}) & \text { Water content }(\mathrm{mm}) \mathrm{H}_{2} \underline{0} \\ \text { USGS } 22 & 286 & 59 \\ \text { USGS } 83 & 302 & 58 \\ \text { Site } 9 & 248 & 50\end{array}$

The high water content is due to thawing and refreezing of the snow caused by solar radiation over the long duration of snow cover at the INEL (approximately mid-December 1977 through sampling on February 2, 1978).

Samples from the vicinity of USGS 22 and USGS 83 yie1d waters of similar chemistry (table 9). With the exception of the anomalously high potassium (up to $2.2 \mathrm{mg} / \mathrm{L}$ ) these analyses are similar to the average values reported for precipitation in Pocate11o, Idaho, for July 1955 to June 1956 (Junge and Werby, 1958).

Water from sample site 9, while chemically balanced, shows anomalously high concentrations of sodium $(9.1 \mathrm{mg} / \mathrm{L})$ and bicarbonate $(29 \mathrm{mg} / \mathrm{L})$ and is suspected of being contaminated by $\mathrm{NaHCO}_{3}$ from surface sediments. The lack of electro-neutrality of the analyses, ranging from 2.5 to 14 percent, is a function of the very low concentrations of all ions in solution. Analytical discrepancy of $0.1 \mathrm{mg} / \mathrm{L}$ in some cases could cause up to a 10 percent error at these low concentrations.

Samples from precipitation events in excess of $1 \mathrm{~mm}$ total moisture were analysed for deuterium and oxygen-18 content. The $\delta \mathrm{D}_{\mathrm{SMOW}}$ for individual events ranged from -33.6 to $-224.5 \%$; the $\delta^{18}{ }^{0}$ SMOW for those same events ranged from -4.40 to $-27.65 \%$ oo (table 10 and figure 12). Rightmire and Lewis (1987) document and describe the $\delta$ notation. 
Table 9.--Chemistry of the snowpack and average atmospheric precipitation atselected locations-February 2, 1978 (in $[\mathrm{mg} / \mathrm{L}] /[\mathrm{meq} / \mathrm{L}]$, unless noted otherwise.) ${ }^{1}$

\begin{tabular}{|c|c|c|c|c|}
\hline \multirow{2}{*}{$\begin{array}{l}\text { Chemical } \\
\text { Characteristic }\end{array}$} & \multicolumn{3}{|c|}{ Snowpack } & \multirow{2}{*}{$\begin{array}{c}\text { Average } \\
\text { atmospheric } \\
\text { precipitation } \\
\text { Pocate } 110^{2}(\mathrm{mg} / \mathrm{L})\end{array}$} \\
\hline & USGS - 22 & USGS - 83 & Site 9 & \\
\hline $\mathrm{Ca}^{2+}$ & $0.8 / 0.040$ & $0.1 / 0.050$ & $1.7 / 0.085$ & 1.01 \\
\hline $\mathrm{Mg}^{2+}$ & $0.1 / 0.009$ & $0.2 / 0.017$ & $0.5 / 0.042$ & \\
\hline $\mathrm{K}^{+}$ & $0.8 / 0.021$ & $2.2 / 0.057$ & $0.4 / 0.011$ & 0.09 \\
\hline $\mathrm{Na}^{+}$ & $0.1 / 0.005$ & $0.2 / 0.009$ & $9.1 / 0.396$ & 0.21 \\
\hline $\mathrm{HCO}_{3}^{-}$ & $2 / 0.033$ & $5 / 0.082$ & $29 / 0.476$ & \\
\hline $\mathrm{CO}_{3}^{2-}$ & 0 & 0 & 0 & \\
\hline $\mathrm{C} 1^{-}$ & $0.3 / 0.009$ & $0.8 / 0.023$ & $0.7 / 0.020$ & 0.11 \\
\hline $\mathrm{F}^{-}$ & $0.1 / 0.006$ & $0.1 / 0.006$ & $0.1 / 0.006$ & \\
\hline $\mathrm{OH}^{-}$ & 0 & 0 & 0 & \\
\hline $\mathrm{SO}_{4}^{2-}$ & $2.3 / 0.048$ & $3.1 / 0.065$ & $2.8 / 0.059$ & \\
\hline $\mathrm{SiO}_{2}(\mathrm{mg} / \mathrm{L})$ & 1.1 & 1.5 & 0.3 & 1.95 \\
\hline $\mathrm{pH}$ & 5.0 & 5.0 & 5.4 & \\
\hline $\begin{array}{l}\text { Specific } \\
\text { conductance }\end{array}$ & 8 & 16 & 50 & \\
\hline
\end{tabular}

1 Analyzed by the U.S. Geological Survey Central Laboratory, Denver, Co except as noted.

3 From Junge and Werby (1958).

3 In microsiemen per centimeter at $25 \circ \mathrm{C}$. 
Table $10, \cdots \delta D_{\text {SHOW }}$ and $\delta{ }^{18} O_{\text {SMOW }}$ values for Idaho Falls precipitation samples (Analyzed by Centre D'Etudes Nucléaires De Saclay, Gif-Sur-Yvette, France)

\begin{tabular}{|c|c|c|c|c|c|}
\hline $\begin{array}{l}\text { Sample } \\
\text { tumber }\end{array}$ & Type & Date & $\begin{array}{l}\text { Amount } \\
\left(\operatorname{mm} \mathrm{H}_{2} \mathrm{O} \text { ) }\right.\end{array}$ & $\begin{array}{l}\delta D_{\text {SMOW }} \\
(\% / 00)\end{array}$ & $\begin{array}{l}\delta^{18} O_{\text {SMOW }} \\
(\% / 00)\end{array}$ \\
\hline INEL- 1 & Rain & Sept. 6, 1976 & 1.4 & -52.00 & -6.75 \\
\hline$: 2$ & Rain & Sept. 11-12, 1976 & 7.8 & -125.50 & $-16 \cdot 30$ \\
\hline-3 & Rain & Sept. $17-18,1976$ & 2.8 & -85.65 & -11.80 \\
\hline-4 & Rain & Sept. $19-20,1976$ & 2.0 & -90.70 & -11.65 \\
\hline-5 & Rain & Sept. 22, 1976 & 1.0 & -67.10 & -7.40 \\
\hline-6 & Rain & Oct. $2-3,1976$ & 21.7 & -140.60 & -19.10 \\
\hline-7 & Rain & Oct. 25,1976 & 3.0 & -129.40 & -16.75 \\
\hline-8 & Snow & Dec. 4.5. 1976 & 2.2 & -224.45 & -27.65 \\
\hline-9 & Snow & Jan. 1-4, 1977 & 20.0 & -171.30 & -22.00 \\
\hline-10 & Snow & Jan. 7, 1977 & 3.6 & -178.35 & -23.35 \\
\hline-11 & Snow & Jan. $24-28,1977$ & 3.5 & -126.50 & -16.70 \\
\hline-12 & Rain & Feb. 21,1977 & 4.6 & -127.35 & -16.45 \\
\hline-13 & Snow & Mar. 1, 1977 & 1.8 & -126.00 & -16.25 \\
\hline-14 & Snow & Mar. 2, 1977 & 2.3 & -137.25 & -18.20 \\
\hline-16 & Rain \& Snow & Mar. 9-10, 1977 & 7.9 & -123.70 & -16.35 \\
\hline-17 & Snow & Mar. $18-19,1977$ & 1.9 & -143.90 & -17.80 \\
\hline-18 & Snow & Mar. 28, 1977 & 5.4 & -117.65 & -15.70 \\
\hline-19 & Snow & Apr. 1, 1977 & 5.0 & -194.15 & -24.10 \\
\hline-20 & Rain \& Snow & Apr. 14,1977 & 2.8 & -125.25 & -16.30 \\
\hline INEL- 21 & Rein & May $6-7,1977$ & 5.4 & -75.00 & -10.35 \\
\hline-22 & Rain & May 11. 1977 & 10.4 & -112.20 & -15.50 \\
\hline-23 & Rain & May 14,1977 & 3.2 & -64.05 & -7.95 \\
\hline .24 & Rain & May 18-19, 1977 & 8.1 & -125.55 & -16.40 \\
\hline-25 & Rain & May 19. 1977 & 2.2 & -149.45 & -19.00 \\
\hline-26 & Rain & May 22,1977 & 3.4 & -86.50 & -10.95 \\
\hline-27 & Rain & May $24-25,1977$ & 3.2 & -143.55 & -17.35 \\
\hline-28 & Rain & June 7,1977 & 1.8 & -35.60 & -4.40 \\
\hline-29 & Rain & June 8,1977 & 1.2 & .33 .60 & -4.45 \\
\hline-32 & Rain & June 9,1977 & 3.5 & .47 .55 & -7.50 \\
\hline-30 & Rain & June 10,1977 & 8.5 & -39.50 & -6.35 \\
\hline-33 & Rain & June 20,1977 & 12.3 & -76.45 & -10.85 \\
\hline-35 & Rain & July 3, 1977 & 2.3 & -75.05 & -8.80 \\
\hline-34 & Rain & July 4, 1977 & 9.0 & -97.45 & -13.10 \\
\hline-36 & Rain & Aug. $2-5,1977$ & 4.0 & -68.90 & -9.95 \\
\hline-37 & Rain & Aug. 13,1977 & 15.7 & -46.60 & -6.15 \\
\hline-38 & Rain & Aug. $25-26,1977$ & 7.0 & -83.95 & -10.70 \\
\hline$-39 R$ & Rain & Aug. 27,1977 & 2.4 & -125.35 & -15.35 \\
\hline$-40 R$ & Rain & Sept. 15,1977 & 1.6 & -53.05 & -6.05 \\
\hline-41 & Rain & Spet. 17,1977 & 1.0 & -132.80 & -17.05 \\
\hline-42 & Rain & Sept. $29-30,1977$ & 7.6 & -87.35 & -11.50 \\
\hline INEL-43 S & Snow 1 & Nov. $20-21,1977$ & 13.5 & -160.15 & -21.05 \\
\hline \multicolumn{3}{|c|}{ Total and welghted averages ${ }^{2}$} & 214.6 & -109.85 & -14.48 \\
\hline \multirow[t]{3}{*}{ Composite } & \multicolumn{2}{|c|}{ precipitation ${ }^{3}$ Dec. 1977} & - & .117 .2 & -15.6 \\
\hline & & Jan. 1978 & $-\cdot$ & -143.5 & -16.4 \\
\hline & & Feb. 1978 & $\cdots$ & -133.7 & -17.2 \\
\hline
\end{tabular}

\footnotetext{
1 Included in plot and linear regression but not in weighted average because sample taken November 5-6 was not analyzed.

2 From August 25, 1976, through October 31, 1977.

3 Monthly composite samples collected by NOAA at CFA.
} 


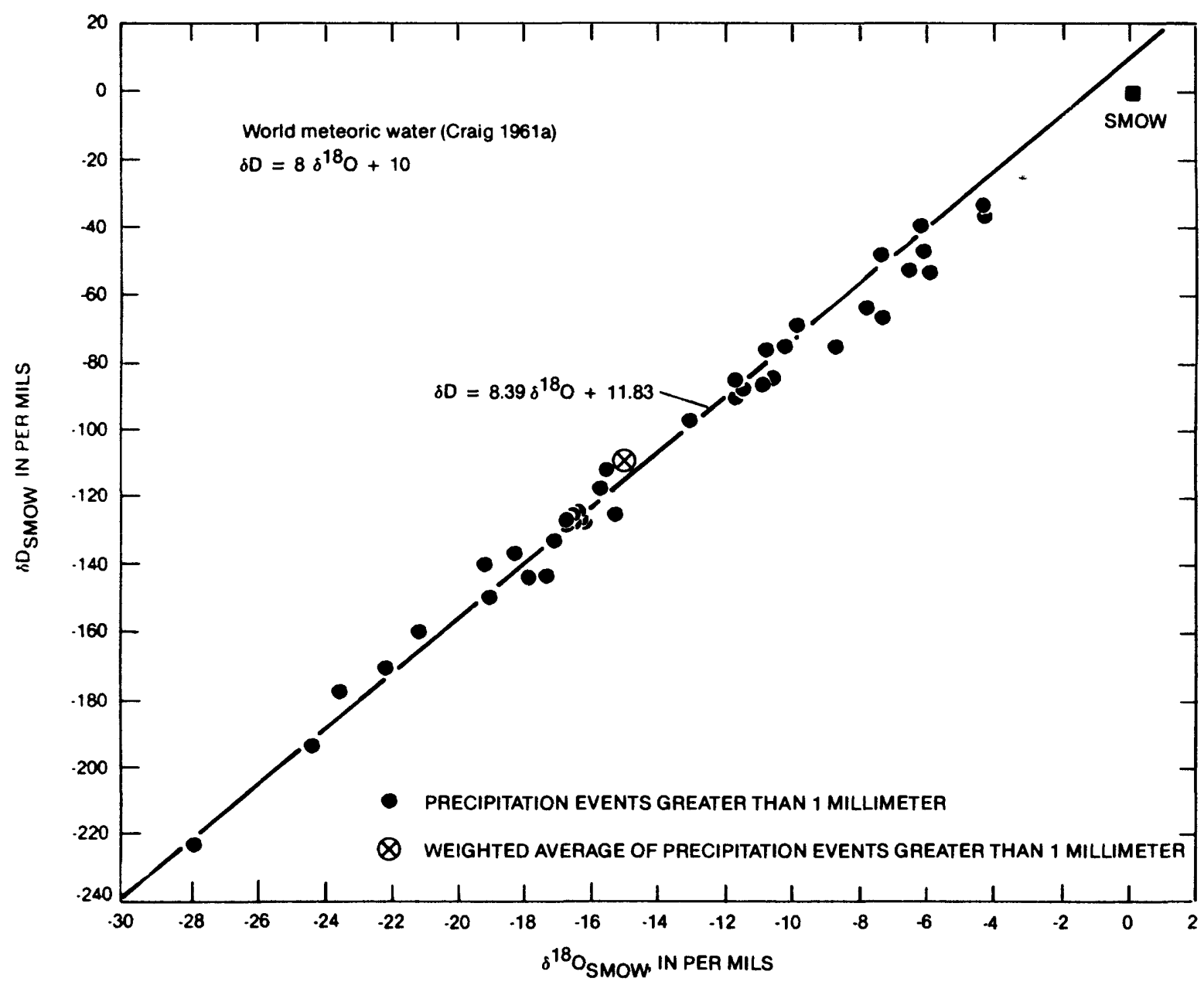

Figure 12.-Plot of $\delta D_{\text {SMOW }}$ as a function of $\delta{ }^{18} 0{ }_{\text {SMOW }}$ values for Idaho Falls precipitation samples (September 1976-October 1977). 
The normal relation between deuterium and oxygen-18 in worldwide precipitation as reported by Craig (1961a) is expressed by the equation:

$$
\delta D=8 \delta^{18} 0+10
$$

A linear regression analysis of the data presented here yields a line defined by the equation:

$$
\delta \mathrm{D}=8.39 \delta^{18} 0+11.83 \text {, }
$$

indicating that, even in a drought year, the stable-isotope composition of local precipitation closely approximates the expected values.

The weighted average of the isotopic composition of precipitation relative to precipitation amount yields a $\delta \mathrm{D}$ value of $-109.8^{\circ} \%$ oo and a $\delta^{18} 0$ value of $-14.48 \%$ o . These values are higher (enriched in the heavy isotope) than one would expect for this location (Friedman and others, 1964; Sheppard, Nielson, and Taylor, 1969). Friedman and others (1964) report a $\delta D$ value for Jackson Lake, Wyoming, felt to represent precipitation over the Upper Snake River drainage, of $-132 \%$ oo and for Carey Lake, Carey, Idaho, of $-121 \%$. The higher deuterium value evidenced by the weighted average of the 1976-77 precipitation samples may be related to the drought conditions prevalent across the area.

Chemical analyses of the snowpack samples were evaluated by the computer program WATEQF (Plummer, Jones, and Truesde11, 1976) to compute the equilibrium $\mathrm{P}_{\mathrm{CO}_{2}}$ of these waters. Because of the dilute nature of these waters, very slight inaccuracies on the determination of any of the ionic species would have significant impact on the calculated speciation of the water. With this in mind, care must be taken not to give excess importance to the actual chemical analyses of these waters, but to use the generalized chemistry as a starting point for looking at chemical changes that result from reactions within the unsaturated zone.

The $\log \mathrm{P}_{\mathrm{CO}_{2}}$ value for atmospheric gases is -3.48 , and it is assumed that snowpack waters are in equilibrium with these gases. The solubility of $\mathrm{CO}_{2}(\mathrm{~g})$, at $\mathrm{O} \circ \mathrm{C}$, at a $\log \mathrm{P}_{\mathrm{CO}_{2}}$ of -3.48 is $10^{-4.59} \mathrm{moles} / \mathrm{L}$. The calculated $\log \mathrm{P}_{\mathrm{CO}_{2}}$ values for the three snowpack samples are: 


\begin{tabular}{lc} 
Sample location & $\log \mathrm{P}_{\mathrm{CO}_{2}}$ \\
\hline SNOW - USGS 22 & -3.32 \\
SNOW - USGS 83 & -3.32 \\
SNOW - Site 9 & -3.72
\end{tabular}

in confirmation of the above assumptions.

Pearson and Fisher (1971) suggest that all the bicarbonate present in precipitation is derived from atmospheric carbonate dust. Removing bicarbonate with a corresponding amount of calcium and equilibrating the water with atmospheric gas yields a resultant water close to average precipitation. This water is approaching the chemical composition of deionized water.

This study reports isotopic analyses of waters from USGS well 4 (see figure 11) that appears to be recharged from partially evaporated Mud Lake water $\left(\delta \mathrm{D}\right.$ of $-121.3^{\circ} / 00, \delta^{18} 0$ of $-14.80 \% / 00$ ). This, in conjunction with the previously mentioned Carey Lake sample, probably represents an approximation of the normal average precipitation on the Snake River Plain. Thus, the weighted values of $\delta D$ of $-110 \%$ and $\delta 0^{18} 0$ of $-14.48 \%$ for the drought period, show an enrichment in both $D$ and ${ }^{18} 0$ which would be expected under drought conditions.

\section{SURFACE WATER}

A sample of Big Lost River water was collected December 7, 1977, at Arco, Idaho, and submitted for a standard chemical analysis (table 11). The water is a calcium-bicarbonate type with small amounts of magnesium and sulfate, and is typical of snowmelt water from a Paleozoic carbonate terrain (White, Hem, and Waring, 1963).

Part of the sample was submitted for deuterium and oxygen-18 analyses $\left(\delta D\right.$ equals $-132.1 \%$ \% $\delta^{18} 0$ equals $-16.55 \%$. These values are representative of higher altitude precipitation at this latitude, as expected for a river draining the higher altitudes of mountain ranges. 
Table 11.--Chemistry of a water sample from the Big Lost River, collected near Butte City, December 7, 1977 (constituents in $\mathrm{mg} / \mathrm{L}$ unless otherwise noted) ${ }^{1}$

Chemical

characteristic
Big Lost River

water sample

$$
\mathrm{Ca}^{2+}
$$

$\mathrm{Mg}^{2+}$

$\mathrm{K}^{+}$

$\mathrm{Na}^{+}$

$\mathrm{HCO}_{3}^{-}$

$\mathrm{CO}_{3}^{2-}$

$\mathrm{Cl}^{-}$

$\mathbf{F}^{-}$

$\mathrm{OH}^{-}$

$\mathrm{SO}_{4}^{2-}$

$\mathrm{SiO}_{2}$

$\mathrm{pH}$

Specific conductance ${ }^{2}$
61

18

1.7

11

260

0

8.2

0.3

0

23

15

6.4

420

1 Analyzed at the U.S. Geological Survey Central Laboratory, Denver, Co.

2 In microsiemen per centimeter at $25 \circ \mathrm{C}$. 
UNSATURATED ZONE GASES

Gases from the shallow soil zone (less than one meter) were collected at a CFA site on the INEL, from April 1977 through February 1978, to determine the composition and the ${ }^{13} \mathrm{C}$ and ${ }^{18} \mathrm{O}$ content of the $\mathrm{CO}_{2}$. Gases from deeper in the unsaturated zone were collected from we11 77-1 but analyses indicated samples were altered by contamination from the cement used during well completion.

Soil gas samples were collected in the manner described by Rightmire and Hanshaw (1973) from a series of sample probes installed at depths of $30.5 \mathrm{~cm}, 61 \mathrm{~cm}$, and $76 \mathrm{~cm}$ in the vicinity of the NOAA meteorological installation at CFA. Samples were collected monthly during the growing season (about May to October) and at longer intervals thereafter to determine seasonal effects on the $\mathrm{CO}_{2}$ concentration and carbon and oxygen isotope content.

Analyses of gas samples showed that the gas composition in the shallow unsaturated zone, with the exception of $\mathrm{CO}_{2}$, is constant (table 12). Carbon dioxide, the gas of principal interest in this study, ranged from 0.033 to 0.19 percent with a mean of 0.082 percent and standard deviation of 0.044 percent. The $\mathrm{CO}_{2}$ concentrations converted to $\log \mathrm{P}_{\mathrm{CO}_{2}}$ values range from -3.48 to -2.72 with a mean of -3.14 and a standard deviation of 0.23 . It should be noted that the variation in $\mathrm{CO}_{2}$ content relative to the total $\mathrm{CO}_{2}$ concentration is significantly greater than for any other constituent. This indicates that the $\mathrm{CO}_{2}$ is very reactive and is gained and lost readily from the system.

Fluctuations in $\log \mathrm{P}_{\mathrm{CO}_{2}}$ and $\delta{ }^{13} \mathrm{C}$ with time for various depths during March 1977 through January 1978 are shown on figure 13. The largest variability in $\log \mathrm{P}_{\mathrm{CO}_{2}}$ values are observed in the samples from the deepesit $(76 \mathrm{~cm})$ probe. The shallow soil zone offers the greatest possibility for gas exchange with the atmosphere due to diffusion in the shallow unsaturated zone. Carbon isotope values $\left(\delta^{13} \mathrm{C}\right)$ of the soil gases range from -8.93 to $-19.59 \%$ oo (table 12 and fig. 13). These values range from near 
Table 12.--INEL Soil gas data, collected at the NOAA weather station, CFA (D.W. Fisher, U.S. Geological Survey, Analyst)

\begin{tabular}{|c|c|c|c|c|c|c|c|c|}
\hline $\begin{array}{c}\text { Sample } \\
\text { date }\end{array}$ & $\begin{array}{l}\text { Depth } \\
(\mathrm{cm})\end{array}$ & $\begin{array}{c}\delta^{13} \mathrm{C} \\
\left({ }^{0} / 00\right)\end{array}$ & $\begin{array}{c}\delta^{18} 0 \\
(\% / 00)\end{array}$ & $\begin{array}{c}\mathrm{N}_{2} \\
\text { (per- } \\
\text { cent) }\end{array}$ & $\begin{array}{c}\mathrm{O}_{2} \\
\text { (per- } \\
\text { cent) }\end{array}$ & $\begin{array}{c}\text { Ar } \\
\text { (per- } \\
\text { cent) }\end{array}$ & $\begin{array}{l}\mathrm{CO}_{2} \\
(\text { percent)/ } \\
\log \mathrm{P}_{\mathrm{CO}_{2}}\end{array}$ & $\mathrm{~N}_{2} / \mathrm{Ar}$ \\
\hline $4-7-77$ & 30.5 & (1) & (1) & 78.2 & 20.6 & 0.98 & $0.19 /-2.72$ & 79.80 \\
\hline $6-23-77$ & $"$ & -10.89 & +27.50 & 77.7 & 21.3 & 0.98 & $0.042 /-3.38$ & 79.29 \\
\hline $7-19-77$ & $n$ & -13.67 & +25.53 & 76.7 & 21.7 & 0.98 & $0.068 /-3.17$ & 78.27 \\
\hline $8-23-77$ & $n$ & -15.44 & +28.84 & -- & -- & Sample & Lost $\quad$. & -- \\
\hline $9-16-77$ & $n$ & -15.12 & +26.40 & 77.4 & 21.6 & 0.97 & $0.062 /-3.21$ & 79.79 \\
\hline $10-27-77$ & $n$ & -13.51 & +33.99 & 77.3 & 21.6 & 1.00 & $0.049 /-3.31$ & 77.30 \\
\hline $11-22-77$ & $"$ & -10.34 & +23.42 & $74.8^{2}$ & $24.2^{2}$ & $0.94^{2}$ & $0.036 /-3.44$ & 79.57 \\
\hline $2-16-78$ & 30.5 & -10.52 & +36.93 & 78.8 & 20.1 & 1.02 & $0.039 /-3.41$ & 77.25 \\
\hline $4-7-77$ & 61 & -8.93 & +37.82 & 77.7 & 21.3 & 0.95 & $0.033 /-3.48$ & 81.79 \\
\hline $6-23-77$ & $n$ & -12.13 & +17.45 & -- & -- & \multicolumn{2}{|c|}{ Insufficient Sample } & $-\cdots$ \\
\hline $7-19-77$ & $n$ & -10.80 & +31.96 & 76.8 & 21.9 & 0.97 & $0.049 /-3.31$ & 79.18 \\
\hline $8-23-77$ & $"$ & -10.60 & +34.60 & 77.0 & 21.9 & 0.98 & $0.041 /-3.39$ & 78.57 \\
\hline $9-16-77$ & $"$ & -14.85 & +22.55 & 77.3 & 21.6 & 1.01 & $0.093 /-3.03$ & 76.53 \\
\hline $10-27-77$ & $n$ & -10.17 & +25.57 & $76.8^{2}$ & $22.2^{2}$ & $1.02^{2}$ & $0.040 /-3.40$ & 75.29 \\
\hline $11-22-77$ & $n$ & -9.79 & +36.13 & $74.8^{2}$ & $24.2^{2}$ & 0.94 & $0.034 /-3.47$ & 79.57 \\
\hline $2-16-78$ & 61 & -17.21 & +22.14 & 78.7 & 20.1 & 1.04 & $0.108 /-2.97$ & 75.67 \\
\hline $4-7-77$ & 76 & -10.86 & +35.80 & 77.7 & 21.3 & 0.99 & $0.039 /-3.41$ & 78.48 \\
\hline $5-27-77$ & $"$ & -16.68 & +20.46 & 77.8 & 21.0 & 1.02 & $0.12 /-2.92$ & 76.27 \\
\hline $6-23-77$ & $n$ & -19.59 & +6.86 & 77.7 & 21.2 & 0.97 & $0.12 /-2.92$ & 80.10 \\
\hline $7-19-77$ & $"$ & -15.52 & +24.53 & 76.6 & 21.7 & 0.99 & $0.146 /-2.84$ & 77.37 \\
\hline $8-23-77$ & $n$ & -15.47 & +24.94 & 76.7 & 21.8 & 0.99 & $0.112 /-2.95$ & 77.47 \\
\hline $9-16-77$ & $"$ & -17.39 & +21.10 & 77.4 & 21.5 & 0.98 & $0.091 /-3.04$ & 78.97 \\
\hline $10-27-77$ & $"$ & -15.44 & +26.26 & $76.7^{2}$ & $22.2^{2}$ & $1.02^{2}$ & $0.070 /-3.16$ & 75.20 \\
\hline $11-22-77$ & $n$ & -9.78 & +35.47 & $74.9^{2}$ & $24.2^{2}$ & $0.93^{2}$ & $0.034 /-3.47$ & 80.54 \\
\hline $2-16-78$ & 76 & -16.40 & +26.92 & 78.7 & 20.1 & 1.05 & $0.082 /-3.09$ & 74.95 \\
\hline Standard & aix & $-7.00^{3}$ & +41.00 & 78.16 & 20.89 & 0.93 & $0.033 /-3.48$ & 83.75 \\
\hline
\end{tabular}

Insufficient samples.

Data only approximate, equipment malfunction.

Ranges from -6.6 to -12.8 over continental land masses (Keeling, 1961) 

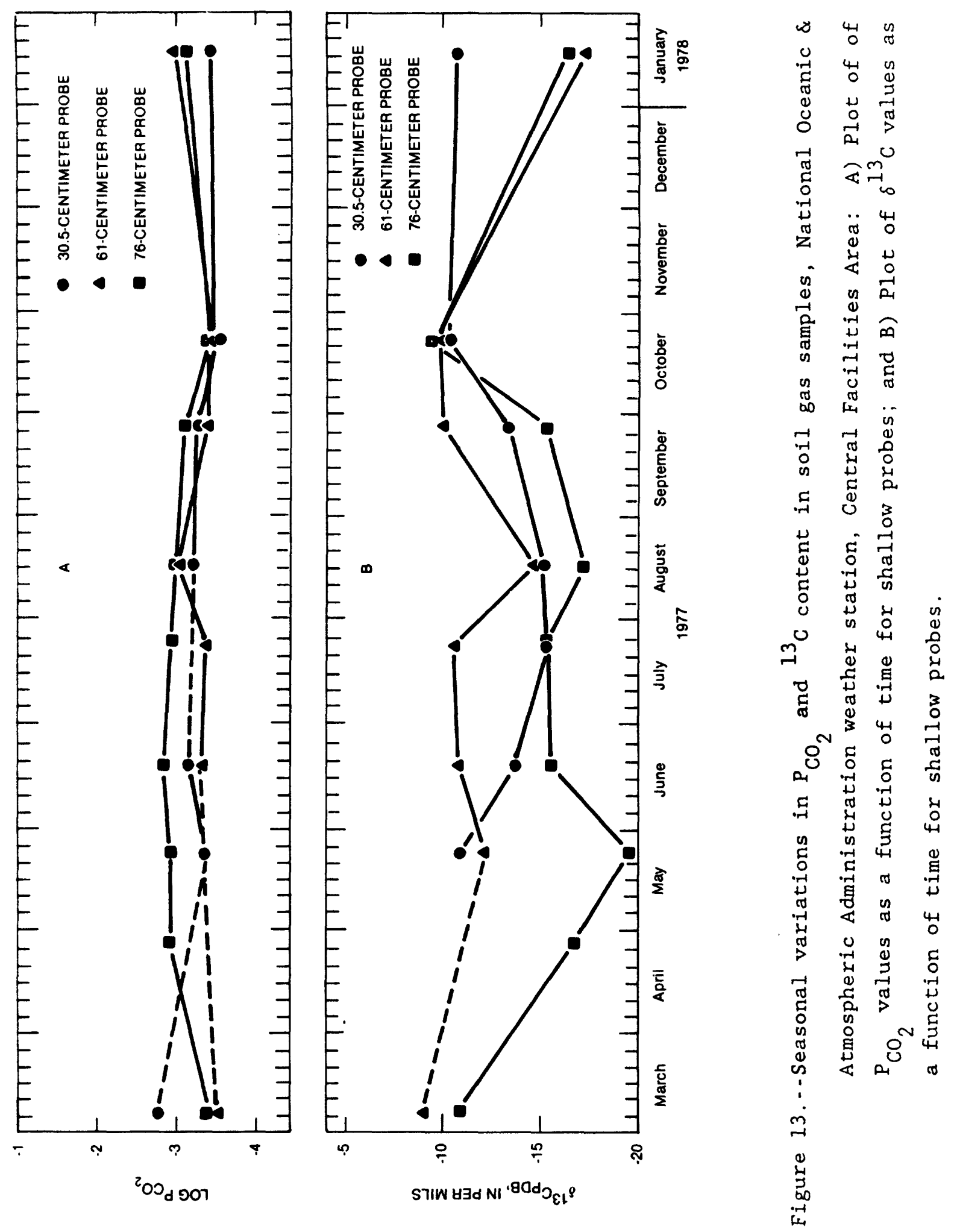
atmospheric to those expected in semiarid environment of sparse vegetation (Rightmire, 1978b). Air has a $\log \mathrm{P}_{\mathrm{CO}_{2}}$ of -3.48 and a $\delta^{13} \mathrm{C}$ range of -6.6 to $-12.8 \%$ over continental land masses.

Seasonal fluctuations in both $\mathrm{P}_{\mathrm{CO}_{2}}$ and $\delta^{13} \mathrm{C}$ are observed in the soil gases collected from a semiarid environment at the INEL but are much less pronounced than those observed in temperate climates (Rightmire, 1978a). These fluctuations result from several causes. As an example, as the ambient temperature increases in the spring and summer, vegetation and soil microbes respire $\mathrm{CO}_{2}$, leading to an increase in $\mathrm{P}_{\mathrm{CO}_{2}}$ and a corresponding decrease in ${ }^{13} \mathrm{C}$ of the soil $\mathrm{CO}_{2}$.

There is isotopic and chemical evidence that the $61-\mathrm{cm}$ probe leaked during the collection of samples on July 19, August 23, and October 27 , 1977. Analysis of the sample for November 22, 1977 from the same probe might be suspect also, except that the samples above and below the probe also indicate nearly atmospheric gas composition, suggesting that the soil gas was displaced by atmospheric gases during the sampling period.

The effect of barometric pressure on soil gas composition is evident in the shallow subsurface, especially where permeable basalt near the surface is covered by a thin surficial sedimentary layer. During soil gas sampling on April 7-8, June 23-24, and November 21-23, 1977, the eastern Snake River Plain was under the influence of high pressure. All the April and November samples and the two shallower June samples yield carbon isotope values approaching those observed for the atmosphere and suggest that atmospheric gases have displaced soil $\mathrm{CO}_{2}$ downward because ${ }^{13} \mathrm{C}$ values indicate the presence of heavier carbon in the $\mathrm{CO}_{2}$. The middle samples for July, August, and October, 1977 and the shallow February 1978 sample also yield carbon isotope values approaching atmospheric values and may also indicate a similar relationship. The remainder of the samples were collected either while the area was under the influence of atmospheric low pressure when gases were moving out of the shallow unsaturated zone because of the pressure gradient or when conditions were static because ${ }^{13} \mathrm{C}$ values indicate the presence of 1 ighter carbon in the $\mathrm{CO}_{2}$. 
The relatively low $\delta^{13} \mathrm{C}$ values $(-15.47$ to $-19.59 \%$ \%o $)$ and the relatively high $\mathrm{P}_{\mathrm{CO}_{2}}\left(\log \mathrm{P}_{\mathrm{CO}_{2}}\right.$ values of -2.84 to -3.04) observed in the 76 -cm samples obtained during late May through September suggest that those values may be representative of water percolating through the shallow unsaturated zone following late spring, summer, or early autumn's sporadic thunderstorms.

The relatively low $\delta^{13} \mathrm{C}$ values $(-17.21$ and $-16.40 \% / 00)$ and the relatively high $\mathrm{P}_{\mathrm{CO}_{2}}\left(\log \mathrm{P}_{\mathrm{CO}_{2}}\right.$ values of -2.97 and -3.09) observed in samples from the $61-\mathrm{cm}$ and $76-\mathrm{cm}$ probes, respectively in February 1978, after the entire area had been under a snowpack for approximately 2 months, suggest that these values may be representative of snowmelt water percolating into the shallow subsurface in early spring. Snowmelt recharge is probably the dominant mechanism of infiltration through surficial sedimentary material on the eastern Snake River Plain. Except in winters with a snowpack of exceptionally high water content, it is doubtful that more than a small part of this moisture reaches the aquifer. Most of it probably replaces water lost from the shallow surficial material the previous summer by evapotranspiration.

\section{GROUND WATER}

Isolated zones of perched ground water have been encountered in every well drilled at the RWMC. Moisture content of sedimentary samples analyzed by the U.S. Geological Survey (Barraclough, Robertson, and Janzer, 1976) ranged from 9.1 to 45.7 percent. The presence of perched water is indicated by standing water in well 92 at about $64.9 \mathrm{~m}$, and in well 77-2 at $26.33 \mathrm{~m}$, by saturated core material in well 76-1 at $10 \mathrm{~m}$, and by observations by drillers at many locations. Figure 10 shows the depth to perched ground water in the vicinity of the RWMC. Although not limited to that area, most of the perched water was encountered in the northwest quadrant of the RWMC.

The depths noted in figure 10 suggest that perched water zones are related to interflow sedimentary beds. Humphrey and Tingey (1978) note that 
there are four zones of perched water: 1) above the 9-m interbed; 2) at about $20 \mathrm{~m} ; 3$ ) above the 34-m interbed, and 4) above the 73-m interbed.

Table 13 presents chemical analyses of perched-water samples collected from well 92 above the 73-m interbed. The water sample collected April 10 , 1972, may show evidence of reactions with cement used in well completion (Barraclough, Robertson, and Janzer, 1976). While the differences in chemical character of the water from April 10, 1972 to October 20, 1976, may be due at least in part to the cementing, the difference between the October 1976 sample and the May 2, 1977 sample may be due to sample contamination during sampling. However, the perched ground-water samples for October 1976 and May 1977 show only major differences in ionic concentration in calcium and bicarbonate. If the excess calcium is removed to bring the May sample down to the calcium concentration of the October sample and a corresponding amount of bicarbonate is removed, the resulting $300 \mathrm{mg} / \mathrm{L}$ of bicarbonate exceeds the October sample by $10 \mathrm{mg} / \mathrm{L}$. If the $\log \mathrm{P}_{\mathrm{CO}_{2}}$ for the May water is assumed to be the same as for the October water, -3.00 , the calculated $\mathrm{pH}$ is 8.43, almost identical to that for the October sample. The additional calcium carbonate may have been added to the solution when the May sample was bailed from the well. Thus, for practical purposes, the chemistry of the October 1976 and May 1977 water is identical.

Samples of perched ground water from well 92 were analyzed for $D$ and ${ }^{18} 0$ content. Results of the analyses are shown in Table 14 . The stableisotope contents of the 1972 sample, $\delta D$ value of $-135.1 \%$ and $\delta^{18} 0$ value of $-17.25 \%$, oo, agree well with the average for the Snake River Plain aquifer ground water ( $\delta \mathrm{D}$ value of $-136.2 \%$ and $\delta^{18} \mathrm{O}$ value of $-17.53 \%$ oo). The 1976 and 1977 perched-water samples are depleted in $D$ and 180 suggesting influence of diversion pond recharge. Two regional groundwater samples, those from wells ANP 7 and USGS 89 (see figure 11 for well locations), are depleted in $D$ and ${ }^{18} 0$ (table 15) relative to the other regional samples. This depletion of the heavy isotopes may be explained by the fact that the water in ANP 7 enters the Snake River Plain aquifer as underflow from Birch Creek, which drains high mountainous areas. Most of this runoff is from high elevation snowmelt and is generally isotopically 
Table 13.--Chemical analyses of perched ground-water samples from wel1 92 (Analyzed by Geological Survey Central Laboratory, Denver, CO)

\begin{tabular}{|c|c|c|c|c|}
\hline $\begin{array}{l}\text { Chemical } \\
\text { characteristic }\end{array}$ & $\begin{array}{l}\text { Units of } \\
\text { measure - } \\
\text { ment }\end{array}$ & $\underset{1972}{\operatorname{April}} 10$ & $\begin{array}{c}\text { October } 29 \\
1976\end{array}$ & $\begin{array}{c}\text { May 2 } \\
1977\end{array}$ \\
\hline $\mathrm{SiO}_{2}$ (diss) & $\mathrm{mg} / \mathrm{L}$ & 13 & 22 & 22 \\
\hline A1 (diss) & $\mu \mathrm{g} / \mathrm{L}$ & 380 & 330 & 80 \\
\hline $\mathrm{Fe}$ (diss) & $\mu \mathrm{g} / \mathrm{L}$ & 290 & 430 & 50 \\
\hline Mn (diss) & $\mu \mathrm{g} / \mathrm{L}$ & 10 & 70 & 80 \\
\hline Ca (diss) & $\mathrm{mg} / \mathrm{L}$ & 26 & 29 & 42 \\
\hline Mg (diss) & $\mathrm{mg} / \mathrm{L}$ & 25 & 17 & 17 \\
\hline Na(diss) & $\mathrm{mg} / \mathrm{L}$ & 79 & 120 & 120 \\
\hline $\mathrm{K}$ (diss) & $\mathrm{mg} / \mathrm{L}$ & 5.9 & 12 & 12 \\
\hline $\mathrm{HCO}_{3}$ & $\mathrm{mg} / \mathrm{L}$ & 260 & 290 & 340 \\
\hline $\mathrm{CO}_{3}$ & $\mathrm{mg} / \mathrm{L}$ & 10 & 0 & 0 \\
\hline $\mathrm{OH}$ & $\mathrm{mg} / \mathrm{L}$ & 0 & 0 & 0 \\
\hline $\begin{array}{l}\text { Alkalinity } \\
\quad \text { as } \mathrm{CaCO}_{3}\end{array}$ & $\mathrm{mg} / \mathrm{L}$ & 230 & 238 & 280 \\
\hline $\mathrm{SO}_{4}$ (diss) & $\mathrm{mg} / \mathrm{L}$ & 73 & 64 & 67 \\
\hline $\mathrm{Cl}$ (diss) & $\mathrm{mg} / \mathrm{L}$ & 49 & 81 & 81 \\
\hline$F(\operatorname{diss})$ & $\mathrm{mg} / \mathrm{L}$ & - & 0.4 & 0.6 \\
\hline $\mathrm{PO}_{4}$ (diss) & $\mathrm{mg} / \mathrm{L}$ & 0.21 & 0.18 & 0.12 \\
\hline Bromide & $\mathrm{mg} / \mathrm{L}$ & 0.1 & 0.3 & 0.0 \\
\hline Boron (diss) & $\mu \mathrm{g} / \mathrm{L}$ & 110 & 110 & 110 \\
\hline $\mathrm{Sr}$ & $\mu \mathrm{g} / \mathrm{L}$ & 120 & 290 & 350 \\
\hline $\mathrm{pH}$ & & $9.1^{1}$ & 8.39 & 7.67 \\
\hline Temp & $O C$ & 13.5 & 13.5 & 11.9 \\
\hline
\end{tabular}

1 Approximate value, calculated from carbonate chemistry. 
light. The same argument holds for well USGS 89, except that this well is recharged by water diverted from the Big Lost River. The Big Lost River also drains a topographically high area and its water could be expected to be depleted in $D$ and ${ }^{18}$ O.

Table 14.-. Stable isotope content of perched ground-water samples (Analyzed by Centre D'Etudes Nucléaires De Saclay, Gif-Sur-Yvette, France)

\begin{tabular}{rcclcc}
\hline $\begin{array}{l}\text { Sample } \\
\text { number }\end{array}$ & $\begin{array}{c}\text { Sampled } \\
\text { well }\end{array}$ & $\begin{array}{c}\text { Depth } \\
(\mathrm{m})\end{array}$ & $\begin{array}{c}\text { Collection } \\
\text { date }\end{array}$ & $\begin{array}{c}\delta D_{\text {SMOW }} \\
(\% / 00)\end{array}$ & $\begin{array}{c}\delta^{18} \text { O }_{\text {SMOW }} \\
(\%)\end{array}$ \\
\hline INEL-44 & 92 & 64.92 & Apr. 10, 1972 & -135.1 & -17.25 \\
-45 & 92 & 64.92 & Oct. 29, 1976 & -143.5 & -18.30 \\
INEL-46 & 92 & 64.92 & May 2, 1977 & -143.7 & -18.35 \\
& $77-2$ & 26.33 & Mar. 14, 1977 & -141.9 & -18.6 \\
& $77-2$ & 26.33 & Mar. 21, 1977 & -135.7 & -17.4 \\
& $77-2$ & 26.33 & Mar. 31, 1977 & -135.7 & -17.2 \\
\hline
\end{tabular}

A linear regression analysis of the stable-isotope data for all nonperched ground-water samples on the INEL yields a line with the equation of: $\delta D=5.28 \delta^{18} 0-43.67$.

If data from USGS 4 are omitted as an anomalous sample influenced by evaporated recharge from Mud Lake, the 1 inear regression equation becomes:

$$
\delta D=4.80 \delta^{18} 0-52.23 \text {. }
$$

A slope of 8 for such data indicates that the water samples are of meteoric origin while a slope of less than 8 indicates that evaporation has occurred between the precipitation event and the time of isotopic analysis (Dansgaard, 1964; and Craig, 1961a).

Linear regression analysis indicates that most of the ground water has been subjected to some prior evaporation. In figure 14, shallow, perched ground-water samples from well 77-2 (recharge water perched near the 34-m sedimentary interbed) also show an evaporative influence (slope of 4.8). 
Table 15.--Stable isotope content of Snake River Plain aquifer groundwater samples collected during September 1977. (Analyzed by Centre D'Etudes Nucléaires De Saclay, Gif-Sur-Yvette, France)

\begin{tabular}{|c|c|c|c|c|}
\hline $\begin{array}{l}\text { Sample } \\
\text { number }\end{array}$ & $\begin{array}{l}\text { Sampled } \\
\text { well }\end{array}$ & $\begin{array}{l}\text { Depth } \\
\text { (m) }\end{array}$ & $\begin{array}{c}\delta D_{\text {SMOW }} \\
\left({ }^{\circ} / 00\right)\end{array}$ & $\begin{array}{l}\delta^{18} 0 \text { SMOW } \\
(0 / 00)\end{array}$ \\
\hline INEL- 48 & USGS 19 & 89.9 & -138.7 & -18.05 \\
\hline-49 & USGS 22 & 195.1 & -136.0 & -17.15 \\
\hline-50 & USGS 89 & $?$ & -141.6 & -18.25 \\
\hline-51 & USGS 4 & 91.4 & -121.3 & -14.80 \\
\hline-52 & Site 14 & $?$ & -135.0 & -17.25 \\
\hline-53 & ANP 7 & 114.3 & -142.4 & -18.60 \\
\hline-54 & Highway 2 & 234.7 & -136.3 & -17.80 \\
\hline-55 & USGS 21 & 110.3 & -137.0 & -17.85 \\
\hline-56 & USGS 17 & 121.9 & -135.2 & -17.30 \\
\hline-57 & CPP 1 & $?$ & -137.5 & -17.65 \\
\hline-58 & Area II & $?$ & -136.2 & -17.70 \\
\hline INEL- 59 & ANP 9 & 76.2 & -137.1 & -17.90 \\
\hline
\end{tabular}




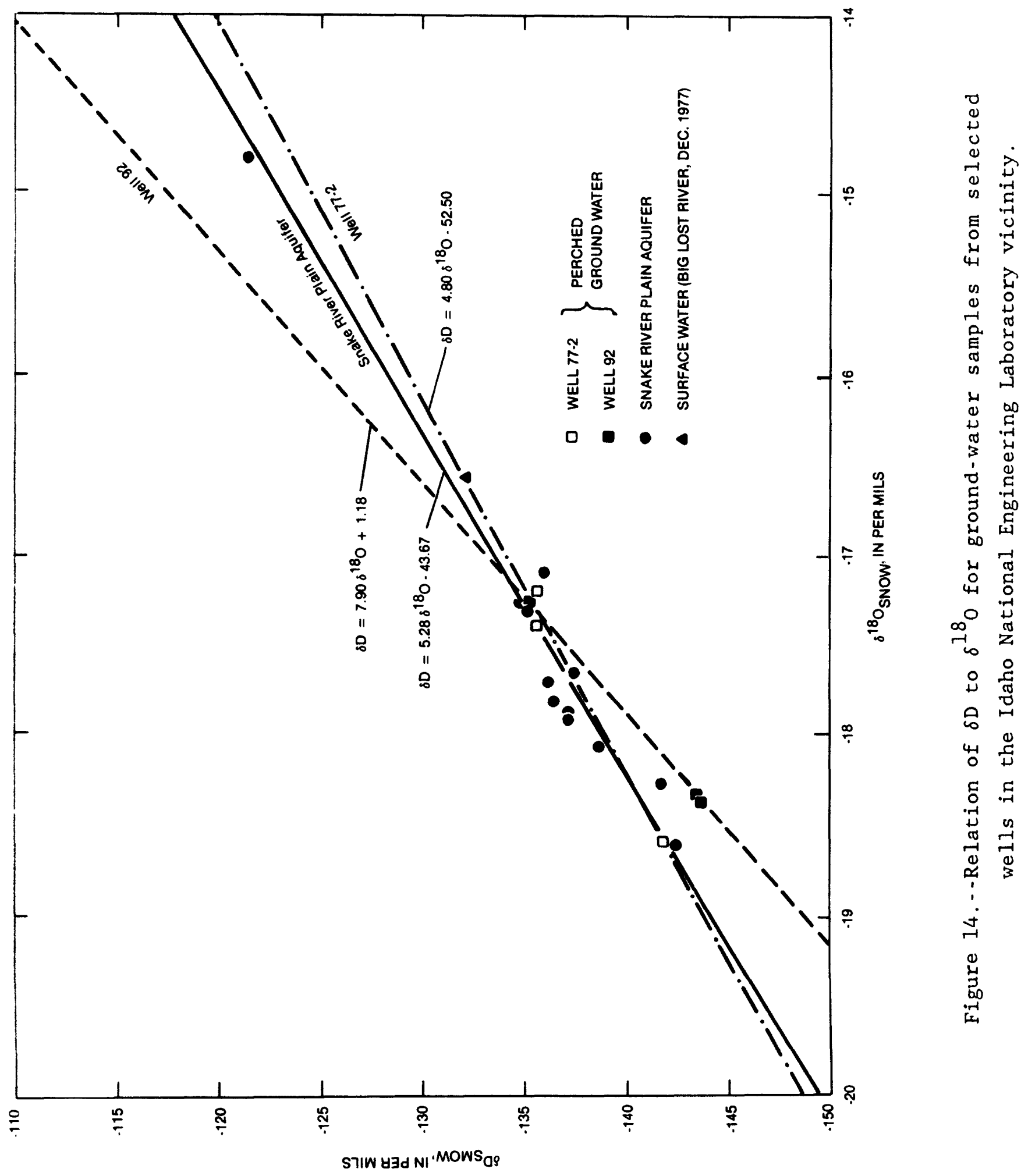


The deeper, perched ground-water samples from well 92 (water perched near the 73 -m sedimentary interbed), on the other hand, show minimal evidence of evaporation (slope of 7.9). It is suggested that the ground water of the Snake River Plain aquifer and that in the shallow perched ground-water in well 77-2, undergo significant evaporation during precipitation or as it infiltrates into a thick unsaturated zone. If the hypothesis of recharge from diversion ponds is accurate, the deeper perched-water body recharged through those ponds is not subject to as much evaporation in the unsaturated zone because recharge continues over a long period of time with large volumes of water at relatively rapid rates.

It appears reasonable, on the basis of the stable isotope content, that the deeper perched water in well 92 is related to the ground water in well 89 which is recharged from the diversion ponds. At present it is not possible to prove conclusively that the deeper perched water beneath the RWMC is derived from diversion-pond recharge, but hydrologic and isotopic evidence strongly suggest this to be the case.

Chemical data from water samples were analyzed using WATEQF (Plummer, Jones, and Truesde11, 1976), a computer program that calculates the chemical equilibria of natural waters on the basis of chemical analysis. The saturation indices of several common minerals are shown in table 16 . It should be noted that, with few exceptions, these water samples are in equilibrium with or oversaturated with respect to the same mineral species. The slight differences in saturation are insignificant.

Many of the mineral phases with which these water samples are oversaturated are those with high cation exchange capacities:

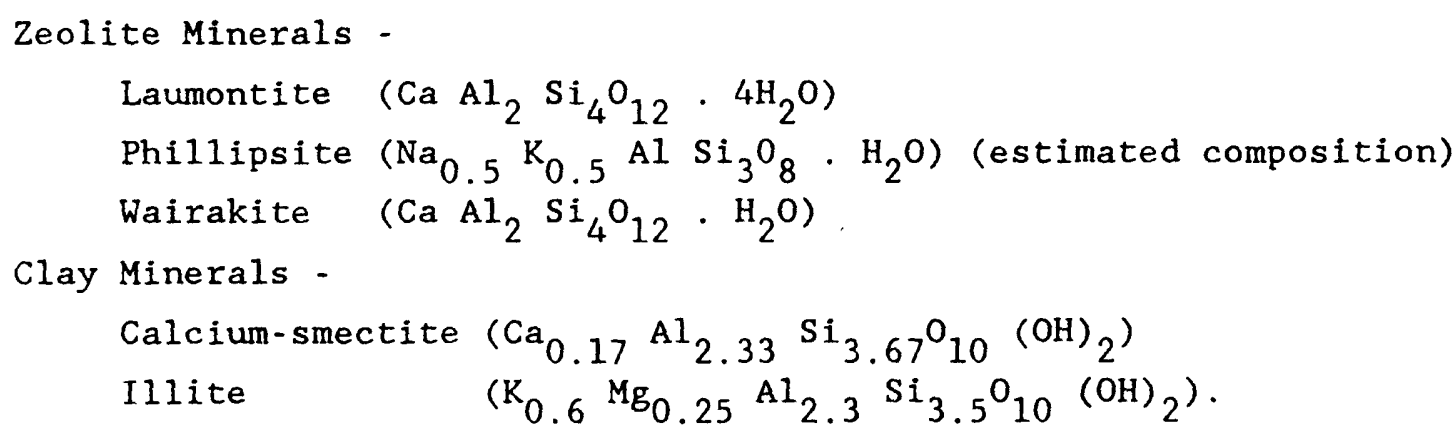




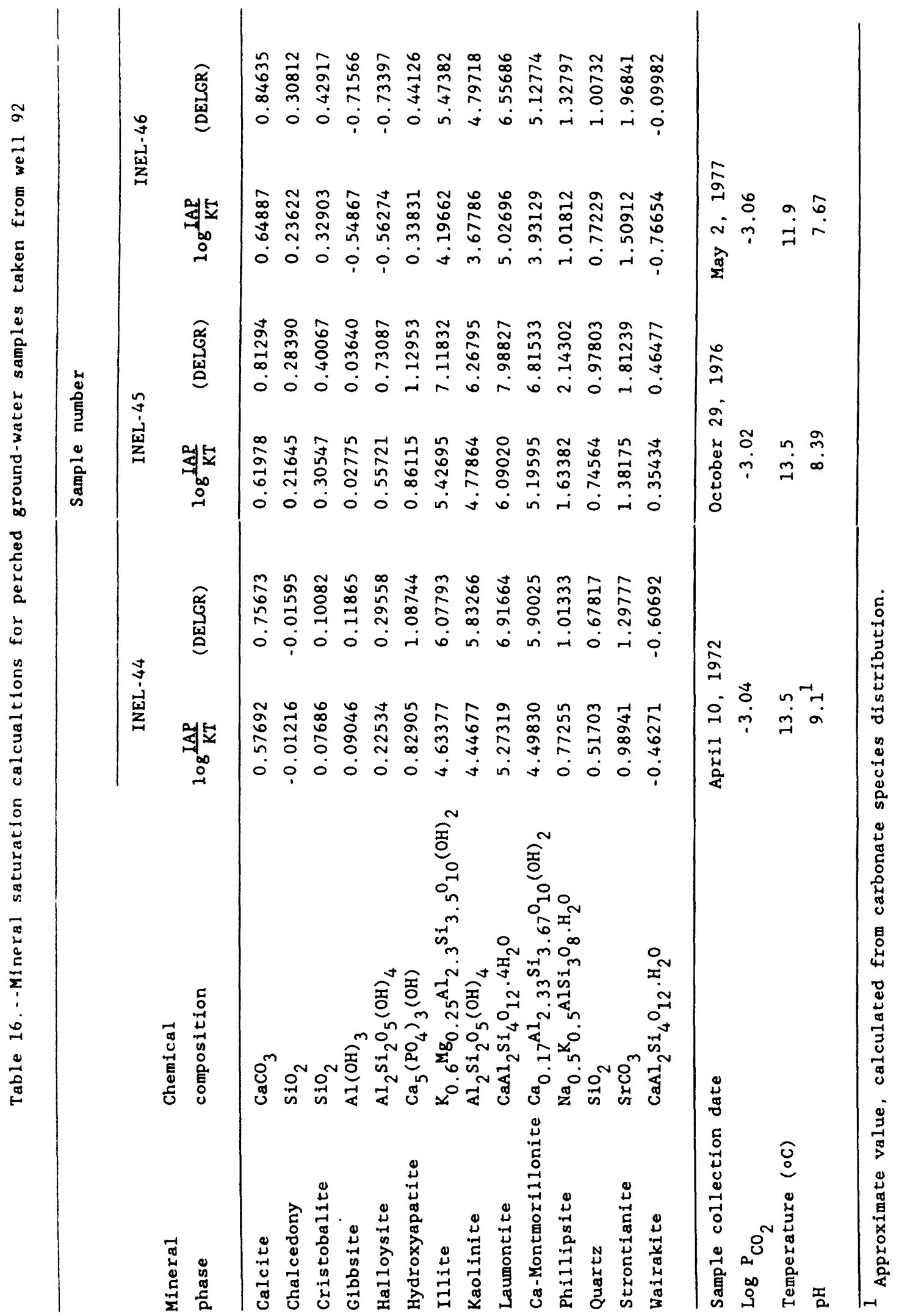


Mixed layer I/S (illite/smectite) clays have chemical, structural, and exchange properties somewhat between those of the pure end members. Hydroxyapatite $\left(\mathrm{Ca}_{5}\left(\mathrm{PO}_{4}\right)_{3}(\mathrm{OH})\right)$, which shows supersaturation in the water samples, has been identified as one of a few mineral anion exchangers used in practical applications (Helfferich, 1962).

The calculated $\mathrm{P}_{\mathrm{CO}_{2}}$ of these water samples $\left(\log \mathrm{P}_{\mathrm{CO}_{2}}\right.$ of $-3.02,-3.06$, and -3.04) very closely approximate the average value for shallow soil gases collected in the area (average $\log \mathrm{P}_{\mathrm{CO}_{2}}$ of -3.14) and is what one would expect for water in a desert environment.

The chemical analyses of water samples suggest that the chemistry of the perched ground water remained relatively constant from 1972 to 1977 . The stable isotope relation of the deeper perched ground water to the underlying regional ground water suggest that the recharge to the aquifer and the deeper perched-water zone may be through the diversion ponds and not directly through the unsaturated zone at the RWMC. The only significant difference in postulating recharge from the Big Lost River water instead of Snake River Plain snowmelt water would be in the chemistry of the input water and the amount of time for potential alteration in water chemistry as the latter moved slowly through the unsaturated zone to the perched-water body. Unfortunately stable-isotope analyses of Big Lost River water prior to 1977 and of water from the diversion ponds do not exist.

STABLE ISOTOPE ANALYSES OF SEDIMENTARY MATERIAL

In addition to core samples from well 76-3, other samples of surficial and other subsurface sediments were collected and analyzed for the stableisotopic composition. Carbon-13 content of the carbonate samples from pit 15 ranges from -8.1 to $+1.1 \%$ (table 17 ). Fluctuations in $\delta^{13} \mathrm{C}$ with depth are shown in figure 15.

The oxygen-18 content of the carbonates also follows the sequence observed in carbonate content (fig. 6) and carbon-13 content. The $\delta^{18}{ }^{\text {SMOW }}$ 
Table 17.--Stable isotope and carbonate content of carbonate-rich surficial sedimentary material-pit 15 (Samples collected during November 1976)

\begin{tabular}{|c|c|c|c|c|c|}
\hline $\begin{array}{l}\text { Sample } \\
\text { number }\end{array}$ & $\begin{array}{c}\text { Depth } \\
(m)\end{array}$ & $\begin{array}{l}\delta^{13} C_{\mathrm{PDB}} \\
(\mathrm{o} / \mathrm{oo})\end{array}$ & $\begin{array}{l}\delta^{18}{ }_{\mathrm{PDB}^{1}} \\
(\% / 00)\end{array}$ & $\begin{array}{l}\delta^{18} 0_{\text {SMOW }} \\
\left({ }^{0} / 00\right)\end{array}$ & $\begin{array}{l}\text { Carbonate } \\
\text { (in percent) }\end{array}$ \\
\hline P $15-2$ & 0.6 & -3.85 & -12.97 & +16.14 & 17.2 \\
\hline $15-3$ & 0.9 & -2.28 & -13.68 & +15.42 & 16.0 \\
\hline $15-4$ & 1.2 & -1.56 & -13.59 & +15.51 & 12.8 \\
\hline $15-5$ & 1.5 & +0.09 & -13.71 & +15.39 & 10.6 \\
\hline $15-6$ & 1.8 & -2.87 & -12.78 & +16.34 & 6.6 \\
\hline $15-7$ & 2.1 & -7.59 & -15.84 & +13.19 & 1.2 \\
\hline $15-8$ & 2.4 & -8.12 & -16.24 & +12.78 & 1.6 \\
\hline $15-9 \quad 1 / 2$ & 2.9 & -7.67 & -16.13 & +12.89 & 4.1 \\
\hline $15-10 \quad 1 / 2$ & 3.2 & -7.23 & -15.83 & +13.20 & 62.9 \\
\hline $15-11 \quad 1 / 2$ & 3.5 & -3.69 & -14.82 & +14.24 & 23.7 \\
\hline $15-121 / 2$ & 3.8 & +1.10 & -14.75 & +14.31 & 8.8 \\
\hline $15-13 \quad 1 / 2$ & 4.1 & -0.98 & -12.22 & +16.92 & 6.2 \\
\hline $15-14 \quad 1 / 2$ & 4.4 & -5.52 & -14.54 & +14.53 & 6.8 \\
\hline $15-15 \quad 1 / 2$ & 4.7 & -6.23 & -16.12 & +12.91 & 7.0 \\
\hline $15-16 \quad 1 / 2$ & 5.0 & \multicolumn{2}{|c|}{ No detectable carbonate } & -- & -- \\
\hline P $15-17 \quad 1 / 2$ & 5.3 & \multicolumn{2}{|c|}{ No detectable carbonate } & $\cdots$ & - \\
\hline
\end{tabular}

1 Average value is $-14.18 \pm 2.05 \%$. 


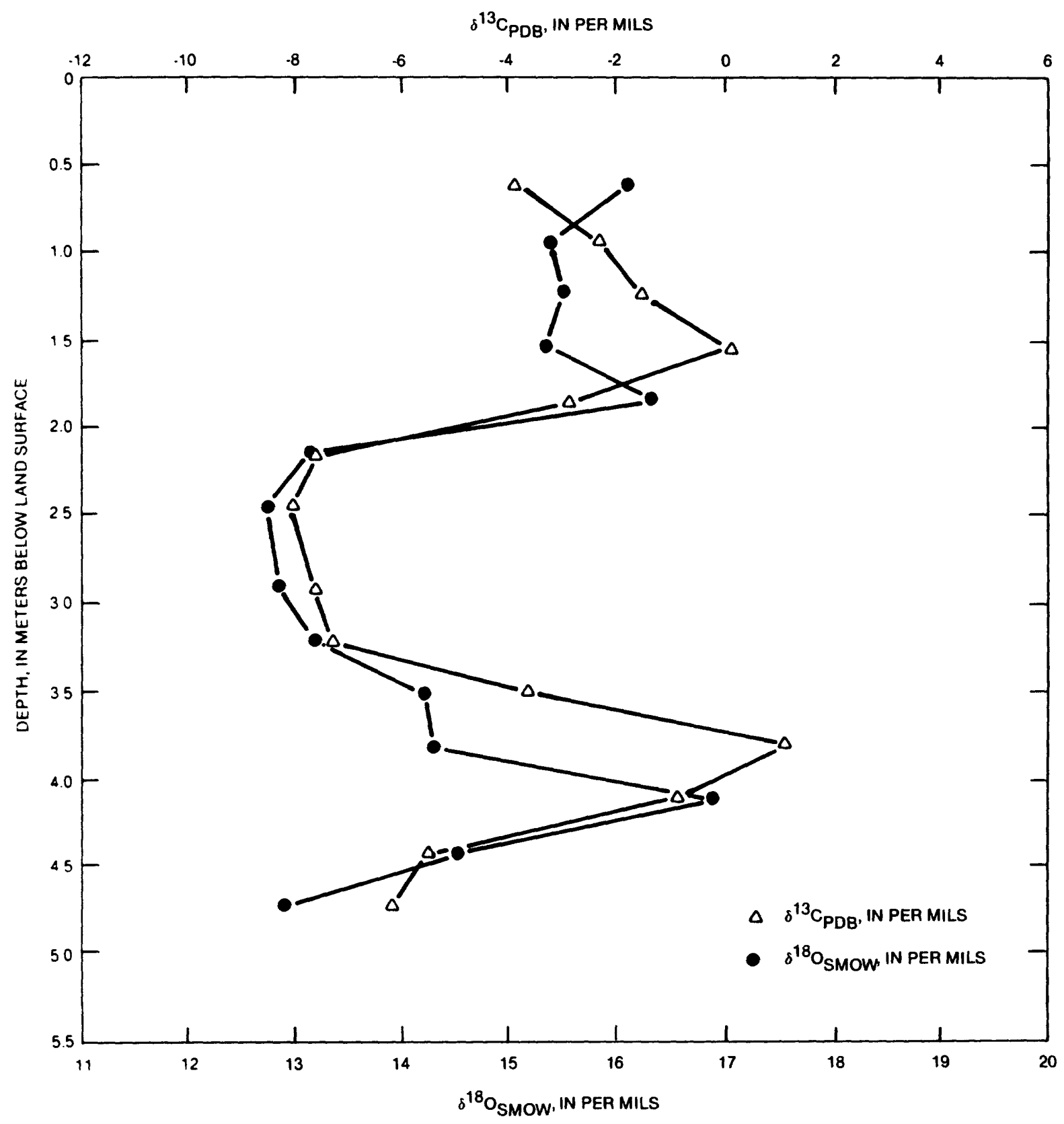

Figure 15.--Values of $\delta^{13} \mathrm{C}$ and $\delta^{18} \mathrm{O}$ as a function of depth for pit 1s samples . 
values fluctuate over a much smaller range, +12.78 to $+16.92 \%$ oo, with a mean of $+14.56 \%$ oo and what appears to be three groupings of values (table 17 and fig. 15.)

The hypothesis of a wetter climate during paleosol development is supported by the carbon and oxygen-isotope contents of the secondary carbonate in the surficial sedimentary material. The upper $2 \mathrm{~m}$ is a lighttan loess with carbonate contents ranging from 17.2 percent in the uppermost sample to 6.6 percent at $1.8 \mathrm{~m}$. The $\delta^{18}$ o values (fig. 15) suggest that the carbonate from $0.9 \mathrm{~m}, 1.2 \mathrm{~m}$, and $1.5 \mathrm{~m}$ was precipitated from waters with similar oxygen-isotope compositions. An apparent trend toward more enriched ${ }^{18} \mathrm{O}$ in the uppermost sample (from $0.6 \mathrm{~m}$ ) suggests the presence of an increasingly warmer and probably drier climate. A study of the ${ }^{13} \mathrm{C}$ and ${ }^{18} \mathrm{O}$ relation and secondary carbonate content with depth suggests that changes in the carbon-isotopic content of the input soil $\mathrm{CO}_{2}$ probably occurs because of increased precipitation which probably is accompanied by changes in the oxygen-isotopic content of atmospheric precipitation.

It appears that the warmest climatic periods, with the exception of the present, occurred during the deposition of carbonates at depths of 1.5 to $1.8 \mathrm{~m}$ and 3.8 to $4.1 \mathrm{~m}$. The enriched ${ }^{18} \mathrm{O}$ and ${ }^{13} \mathrm{C}$ contents of those samples can be attributed to concentration effects of evaporation. The constant $\delta^{13} \mathrm{C}$ of about $-7.5^{\circ} / 00$ between 2.1 and $3.2 \mathrm{~m}$ suggests a fairly stable climate. It is likely that, because this depth represents a transition zone between low and high carbonate content of the soil, the waters moving through the system dissolve $\mathrm{CO}_{2}$ of $\delta^{13} \mathrm{C}$ of about $-20 \%$ oo and precipitate carbonate of about $-8 \%$. No attempt is made here to quantify the ${ }^{13} \mathrm{C}$ system other than to say the $-20 \% / 00 \mathrm{CO}_{2}$ is that which would be derived from vegetation utilizing the $C-3$ photosynthetic pathway. The unit overlying the high carbonate zone is the leached reddish-brown paleosol.

A similar soil sequence is observed underlying the above described sedimentary material between 3.2 and $5.3 \mathrm{~m}$, suggesting a similar climatic sequence to that described above. 
These data suggest that, if the uppermost basalt flow sequence was emplaced 200,000 years ago (Kuntz and others, 1980) then approximately $1.25 \mathrm{~m}$ of loess-type material was deposited on the basalt surface during a period of dry climate. Loess deposition was followed by a wetter period, one with more than about $500 \mathrm{~mm}$ of precipitation a year, which would permit the leaching of the soil and the removal of carbonate and the deposition of alluvial sediments ( $\mathrm{J}$. Hawley, oral commun., 1985). As the climate became drier, eolian aggradation occurred, and carbonate was deposited in the alluvial sediments and the aggrading loess. This is indicated by increases in carbonate content and the ${ }^{13} \mathrm{C}$ and ${ }^{18} \mathrm{O}$ content of the carbonate material.

If precipitation drops below the $500 \mathrm{~mm} /$ year level, the soil surface will continue to aggrade but carbonate accumulation will likely decrease. If the climate becomes wetter, leaching occurs in this aggraded profile and a high $\mathrm{CaCO}_{3}$ unit is developed. The carbon and oxygen-isotope data and the small amounts of carbonate, all suggest a wetter period. A drier interval followed this period of leaching leading to the aggradation of the soil profile and the accumulation of carbonate in that loess.

Oxygen-isotope analyses were conducted on the core samples from well 76-3 that were also analyzed by $x$-ray diffraction. The $\delta^{18}{ }_{\text {SMow }}$ for the clay mineral fraction ranges from +3.38 to $+18.11 \%$ /oo (table 18). Figure 16 shows the distribution of $\delta^{18} 0$ with depth superposed on a generalized stratigraphic section of well 76-3. As shown in table 18, 13 of 28 samples cluster between $+8 \%$ and $+12 \%$, similar to calculated values for authigenic clay minerals in Idaho and Montana soils (Lawrence, 1970; Lawrence and Taylor, 1971).

Three oxygen-isotope determinations warrant specific mention. Two samples, 76-3-5B and 76-3-22B (table 18), are significantly enriched in ${ }^{18_{O}}$ and suggest a different genetic history. Sample 76-3-5B is in the middle of a long vertical fracture from 9.81 to $11.49 \mathrm{~m}$. The sample itself was; collected from 10.42 to $10.55 \mathrm{~m}$. The isotopic value suggests that at least a portion of the clay is not detrital. Sample 76-3-22B is vesicle filling, material which had a $\delta^{18} 0$ value of $+16.08 \%$ oo but contained insufficient clay for $\mathrm{X}$-ray analysis. 
Table 18.--Stable isotope content of clays and carbonate in cored sedimentary material from well 76-3

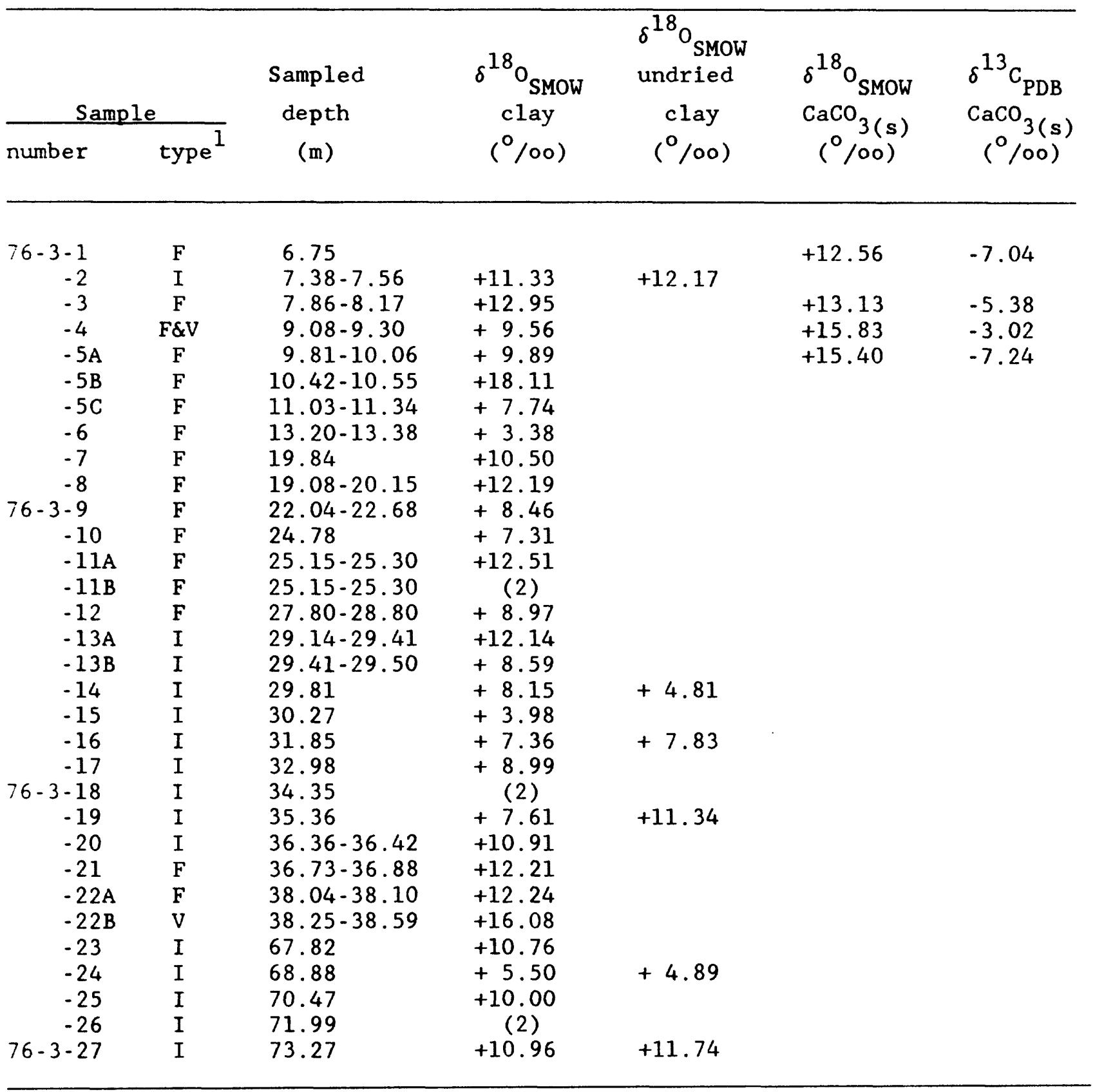

1 F-Fracture-fill sample, I-interbed-flow sample, and V-vesicle sample. 2 Insufficient sample for analysis. 


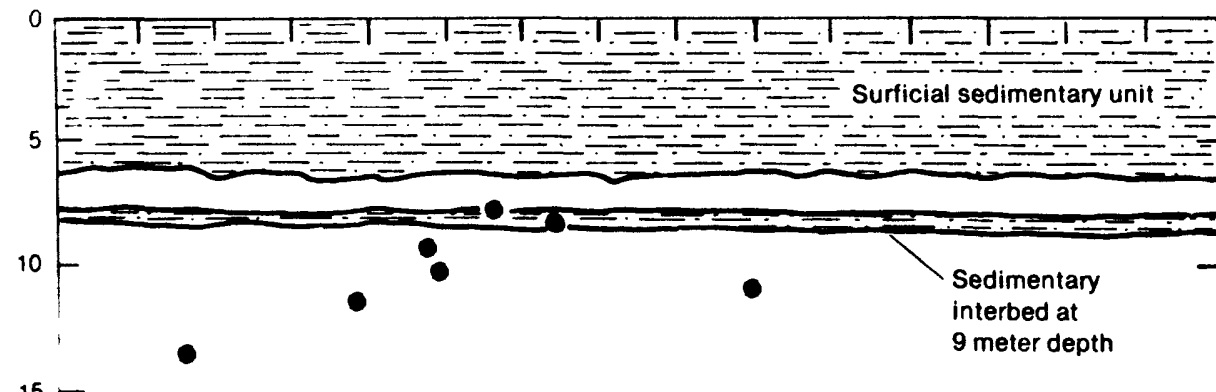

$15-$

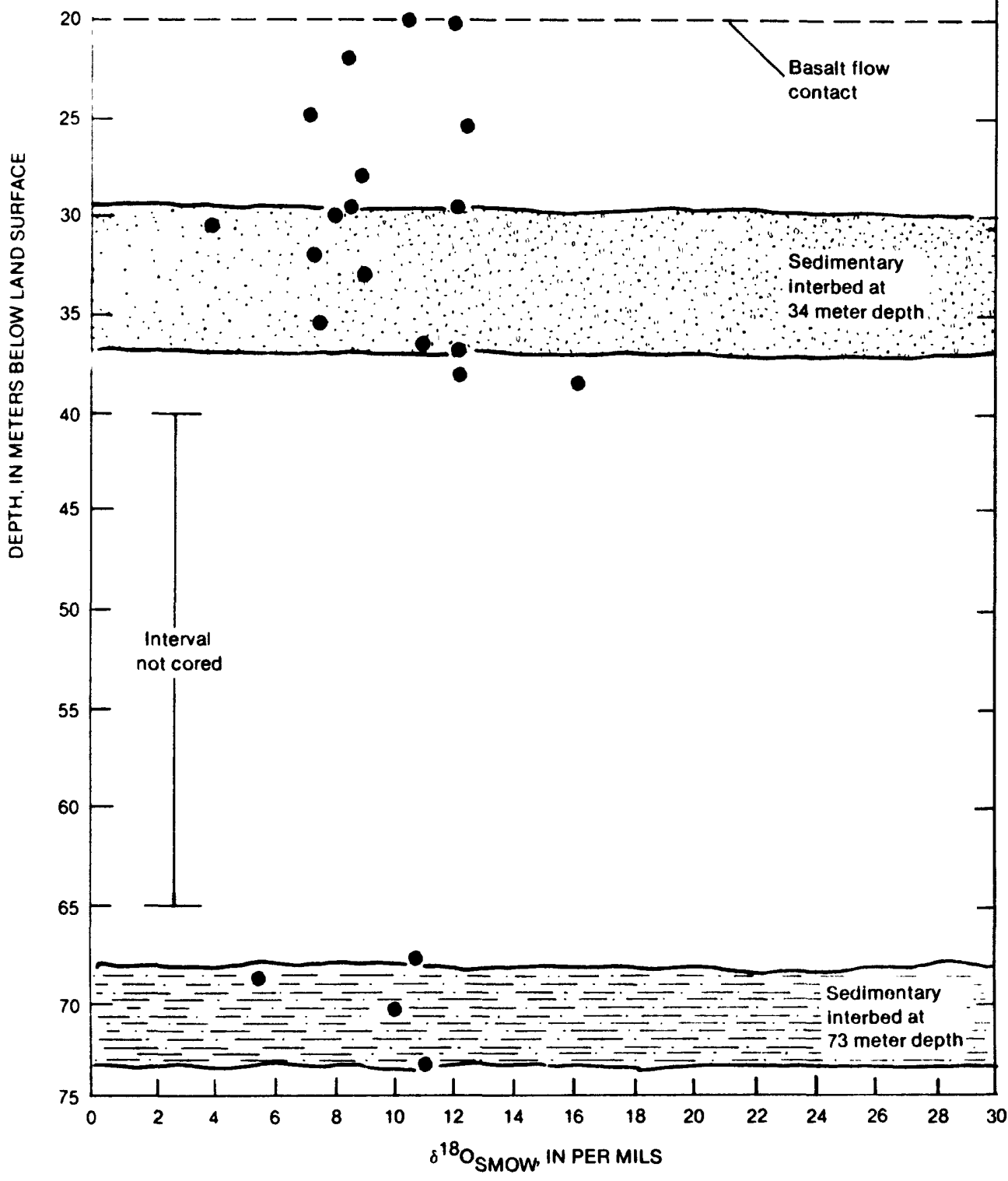

Figure 16.--Relation of $\delta^{18} 0$ of clay minerals with reference to depth in we11 76-3. 
Authigenic amorphous silica sampled at a depth of $35.05 \mathrm{~m}$, lining a fracture $1.83 \mathrm{~m}$ below the base of the $34 \mathrm{-m}$ sedimentary interbed in well $93 \mathrm{~A}$ (see figure 3 for location), yielded an $\delta^{18}$ of of $+20.24 \%$. At a temperature of 6 oC this silica would have precipitated from water with an isotopic composition of $-19.06 \%$.

While it does not appear that there are significant differences between the ${ }^{18} 0$ content of the clays in the individual interbeds suggesting a predominance of detrital clays from the same source, it does appear that the isotopes are useful in differentiating detrital from authigenic clay minerals, an aid in determining interactions with meteoric waters.

Oxygen and carbon isotope determinations were conducted on the carbonate portion of 31 sedimentary samples with sufficient carbonate content for analysis (table 19). Several samples of carbonate from surficial sedimentary material in the vicinity of the RWMC and several overlapping caliche units in a trench across a fault trace on the south side of the Lemhi Range (see figure 2 for location) were analyzed to give control to the samples collected at depth.

Carbon-13 determinations range from -12.29 to $+2.51 \%$, while $\delta^{18} 0$ values ranges from +9.99 to $+18.81 \%$ (table 19). Figures 17 and 18 show the relation of $\delta^{13} \mathrm{C}$ and $\delta^{18} \mathrm{O}$ with depth, respectively.

Mineralogic and stable isotope analyses of the clay minerals and carbonate fractions of the sampled materials give insights into the environment of deposition of the surficial sedimentary material and the sedimentary interbeds. While the differences in oxygen isotope content of the clays in $9-\mathrm{m}, 34-\mathrm{m}$, and $73-\mathrm{m}$ interbeds do not appear to differ sufficiently to utilize ${ }^{18} 0$ content as a tracer, it seems that the clay minerals most enriched in ${ }^{18} 0$ give evidence of authigenic clay mineral formation or alteration. The isotopic content of waters present during deposition of the various interflow sedimentary units can be estimated from the oxygen isotope content of amorphous silica from $35.05 \mathrm{~m}$ in well $93 \mathrm{~A}$ and the carbonates present in the various sedimentary units. 
Table 19.- Carbonate and stable isotope content of carbonatebearing sedimentary samples

\begin{tabular}{|c|c|c|c|c|c|}
\hline \multicolumn{2}{|c|}{ Sample } & \multirow{2}{*}{$\begin{array}{l}\text { Sampled } \\
\text { depth } \\
\text { (m) }\end{array}$} & \multirow{2}{*}{$\begin{array}{c}\delta^{13} \mathrm{C}_{\mathrm{PDB}} \\
\left({ }^{0} / 00\right)\end{array}$} & \multirow{2}{*}{$\begin{array}{l}\delta^{18} \mathrm{O}_{\text {SMOW }} \\
\left({ }^{0} / 0^{\circ}\right)\end{array}$} & \multirow{2}{*}{$\begin{array}{l}\text { Carbonate } \\
\text { (percent) }\end{array}$} \\
\hline designation & type $^{1}$ & & & & \\
\hline \multicolumn{6}{|l|}{$\begin{array}{l}\text { Surficial } \\
\text { Caliche }\end{array}$} \\
\hline GUSGS - 87 & I $(s s)$ & surface & -3.49 & +17.74 & 70.2 \\
\hline EWR - 1 - 2 & I (ss) & 1.37 & -2.22 & +14.09 & 15.2 \\
\hline EWR - 1-3 & I (ss) & 1.60 & -2.15 & +13.50 & 15.8 \\
\hline $76-2-5 a$ & $\mathrm{~V}(>9 \mathrm{~m})$ & 9.11 & +0.73 & +15.66 & 43.5 \\
\hline $76-3-3$ & $\mathrm{~F}(>9 \mathrm{~m})$ & $7.86-8.17$ & -5.37 & +13.13 & 25.4 \\
\hline$-3-4$ & $F \& V \quad(>9 \mathrm{~m})$ & $9.08-9.30$ & -3.02 & +15.83 & 27.1 \\
\hline$-3-5 a$ & $\mathrm{~F}(>9 \mathrm{~m})$ & $9.81-10.06$ & -7.24 & +15.66 & 0.4 \\
\hline $76-4-1$ & $F(>9 \mathrm{~m})$ & $3.60-4.18$ & -7.13 & +13.59 & 13.1 \\
\hline$-4-2$ & $\mathrm{~F}(>9 \mathrm{~m})$ & 5.03 & -6.75 & +13.67 & 23.4 \\
\hline$-4-12 e$ & I $(34 \mathrm{~m})$ & 30.48 & -10.65 & +13.58 & 67.9 \\
\hline $76-4 A-8 d$ & $\mathrm{I}(34 \mathrm{~m})$ & 30.45 & -12.29 & $\begin{array}{c}+12.08 \\
(+12.15)\end{array}$ & $\begin{array}{c}38.4 \\
(38.3)\end{array}$ \\
\hline $76-5-26$ & I $(34 \mathrm{~m})$ & $33.38-34.84$ & -7.60 & +12.81 & 11.8 \\
\hline$-5-27$ & I $(34 \mathrm{~m})$ & 34.99 & -6.79 & +12.90 & 41.3 \\
\hline$-5 \cdot 28$ & $F(>34 m)$ & $36.52-36.73$ & -7.66 & +10.81 & 10.2 \\
\hline $76-6 \cdot 1$ & $\mathrm{~F}(>9 \mathrm{~m})$ & 3.69 & -4.11 & +14.61 & 8.9 \\
\hline$-6 \cdot 2$ & $\mathrm{~F}(>9 \mathrm{~m})$ & 4.60 & -5.91 & +10.25 & 36.3 \\
\hline$-6-3$ & $\mathrm{~F}(>9 \mathrm{~m})$ & $4.75-5.67$ & -4.84 & +9.99 & 38.2 \\
\hline$-6-9$ & I $(34 \mathrm{~m})$ & $31.12-31.76$ & -5.68 & +13.08 & 20.2 \\
\hline $77-2-1$ & $\mathrm{v}$ & $5.33-5.70$ & -6.60 & +13.54 & 89.3 \\
\hline$-2-5$ & $F(>9 \mathrm{~m})$ & 11.09 & +2.51 & +12.22 & 2.3 \\
\hline$-2-7$ & $\mathrm{~F}(>9 \mathrm{~m}$ & $15.54-15.70$ & +1.42 & +14.25 & 86.5 \\
\hline $\mathrm{MH}-16$ & I (ss) & 2.07 & -1.91 & +18.81 & 46.7 \\
\hline $\mathrm{MH}-17$ & $I$ (ss) & 2.07 & -2.25 & +18.16 & 43.6 \\
\hline $\mathrm{MH}-13$ & I (ss) & 2.68 & -2.57 & +16.87 & 44.6 \\
\hline MH - 14 & $I$ (ss) & 2.68 & -2.88 & +16.29 & 43.3 \\
\hline $\mathrm{MH}-10$ & $I$ (ss) & 4.27 & -4.77 & +12.60 & 78.3 \\
\hline $\mathrm{MH}-11$ & & 4.27 & -5.00 & +12.95 & 77.2 \\
\hline
\end{tabular}

1 F-fracture-fill sample, I-interbed-flow sample, and V-vesicle sample: ss-surficial sedimentary sample, $9 \mathrm{~m}-9-\mathrm{m}$ interflow bed sample, and $34 \mathrm{~m}-34-\mathrm{m}$ interflow bed sample. 


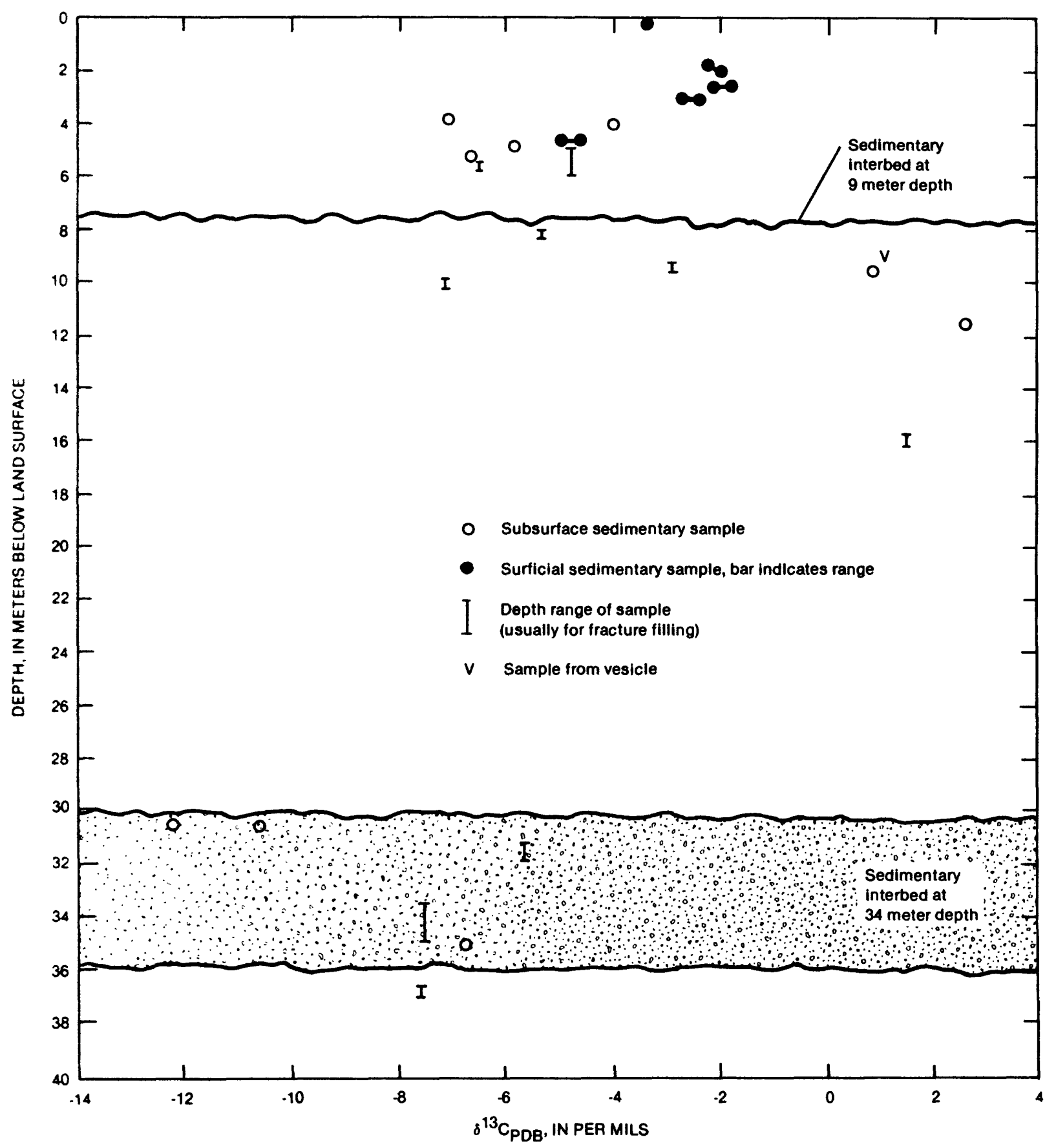

Figure 17.--Relation of $\delta{ }^{13} \mathrm{C}$ with reference to depth for all analyzed carbonate samples from the Radioactive Waste Management Complex vicinity. 


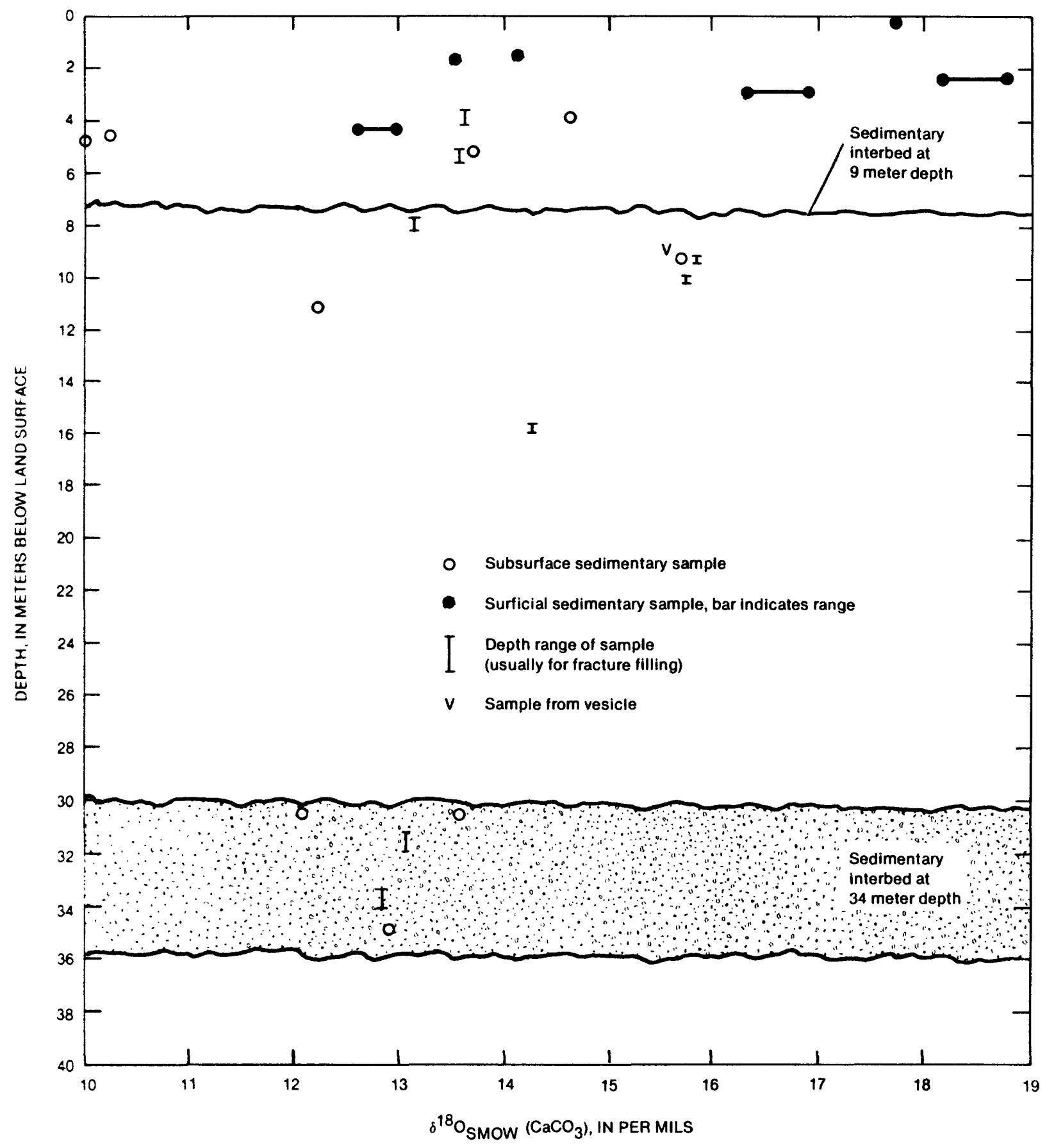

Figure 18.--Relation of $\delta^{18} 0$ with reference to depth for all analyzcd carbonate samples from the Radioactive Waste Management Complex vicinity. 
Meaningful differences in the oxygen isotopic composition of the clay minerals within individual beds were observed. The three samples identified as being 100 percent illite (76-3-14,76-3-24, and 76-3-25; table 8) yield $\delta^{18} 0$ values of $+8.15,+5.50$, and $+10.00 \%$, respectively. If detrital, these illites would likely not be from the same source. However, since 76-3-24 and 76-3-25 are both from the 73-m interbed within $2 \mathrm{~m}$ of each other vertically, they are likely from the same source; that is, the mountains to the west. It must then be concluded that some of the illite is formed or its isotopic composition altered in place.

The possibility that clay minerals near the top of a sedimentary unit will be altered in mineralogy and isotopic composition by an increase in temperature caused by an advancing basalt lava flow must be considered. The color change produced by ferric-oxyhydroxide minerals observed in the sedimentary beds has probably resulted from this heating, thus it is likely that alteration in clay mineralogy and its isotopic composition also would occur.

The in-fracture presence of a mineral phase identified by $X$-ray diffraction as cristobalite (sample 76-1-6c; Rightmire and Lewis, 1987) about $1.26 \mathrm{~m}$ below the flow contact equivalent to the $34-\mathrm{m}$ interbed indicates that it likely formed in the fracture as the younger flow covered its predecessor.

Perry and Hower (1970) note an increase in illite and decrease in I/S clays with depth in sediments in the Gulf coast. They state that temperature is more important than pressure in governing the reaction. Smectite layers (expandable layers) in I/S clays decrease to about 20 percent as temperatures increase to approximately $100 \mathrm{oC}$. At that temperature the irregular interlayering reverts to regular interlayering and remains constant. Conversion of the last 20 percent of smectite layers to illite layers to form discrete illite likely takes place at approximately 200 oC (Hower and others, 1976). Temperatures in excess of 200 oC are certainly reached in shallow sediment as a lava flow advances and could be responsible for the presence of illite as the only clay mineral phase in the top part of the interflow sedimentary units. 
Studies on the kinetics of illite formation (Eberl and Hower, 1976) support the observation of Perry and Hower (1970) that a change in the chemistry of the smectite 2:1 layers must occur before illite can form. At $490 \mathrm{oC}$, glass of the starting composition of $\mathrm{K}$-beidellite (a potassium smectite) crystallized directly into an ordered structure with 30 to 40 percent expandable layers. It is conceivable that at high temperatures (>250 OC) I/S clays could be depleted in expandable layers. A natural reaction proposed by Eber1 and Hower (1976) for smectite to I/S is:

$$
\mathrm{Al}^{3+}+\mathrm{K}^{+}+\text {Smectite }--\rightarrow \mathrm{I} / \mathrm{S}+\mathrm{Si}^{4+} \text {. }
$$

This reaction requires the substitution of aluminum for tetrahedral silicon. The needed aluminum and potassium could be derived from detrital feldspar and micas. The excess silica is observed in the system as cristobalite.

The oxygen isotopic composition of samples 76-3-15 and 76-3-24 (table 18) show significant deviations from the isotopic composition of the other interbed samples both above and below in the same unit. This may be explained by looking at the soil-moisture regime in shallow sedimentary material. Assuming that the climate was semiarid or possibly temperate at the time of inundation by the lava, the average moisture content of approximately the upper meter of a sandy sediment would have been less than 10 percent. As the lava moved across the sedimentary layer, a temperature gradient would be established that would cause water vapor to move deeper into the sedimentary layer. Moisture would then condense at some depth within the sedimentary unit and react with the clay minerals present over a period of time at elevated temperatures. This moisture would be depleted in ${ }^{18} 0$ relative to the average clay mineral phases present and the exchange would lead to a clay mineral depleted in ${ }^{18} 0$. An approximate depletion of $4.6 \%$ is observed for 76-3-15 while a depletion of $5.3 \%$ oo is observed for 76-3-24. The next sample in each interbed is more than $1.5 \mathrm{~m}$ deeper and thus probably insulated from the temperature effect. The underlying samples within the interbeds have approximately the same isotopic composition as the uppermost samples, indicating little or no exchange. 
O'Neil and Kharaka (1976), in studies of isotopic exchange noted that at 350 oC with illite and water, only 7 percent ${ }^{18} 0$ exchange occurred while up to 75 percent deuterium exchange took place. They further state that the mechanism for oxygen exchange between minerals and water involves solution redeposition. The observation suggests that, if mineralogy of these upper samples was altered from other clay mineral phases to illite, the possibility of oxygen re-equilibration is enhanced.

The presence of only small amounts of carbonate in the upper parts of the sedimentary interbeds may in part be due to the temperature effect. If the basalt flow induced temperatures in excess of approximately 600 oc in the shallow sedimentary material, solid calcium carbonate present would thermally decompose yielding $\mathrm{CaO}$ and $\mathrm{CO}_{2(\mathrm{~g})}$. This phenomenon could also be explained by the presence of sufficient moisture to carry dissolved constituents below the top soil layers but insufficient moisture to transport them through the sedimentary layer.

\section{SUMMARY}

The overall objective of this study was to develop a conceptual model of the hydrogeochemical environment of the shallow unsaturated zone of the Snake River Plain, eastern Idaho, and to determine how changes in that environment may influence the mobility and migration of waste radionuclides buried in the subsurface disposal area of the RWMC.

The examination of core material from nine coreholes drilled during 1976-77 was required in addition to the assessment of data reported from previous drilling programs. These drilling programs confirmed the presence of major sedimentary interbeds between basalt flows at depths of about 9 , 34, and 73 meters. The interbed at a depth of $9 \mathrm{~m}$ is thin but locally continuous under the RWMC. The interbed at a depth of $34 \mathrm{~m}$ is absent under the older part of the subsurface disposal area. The interbed at a depth of $73 \mathrm{~m}$ is of irregular thickness, ( 1.25 to $9.48 \mathrm{~m}$ ), and is continuous under the entire RWMC and possibly much of the southwestern part of the INEL. 
Thirteen basalt flows were encountered between land surface and a depth of $184 \mathrm{~m}$. Seven basalt flows were encountered between the base of the surficial sedimentary layer and the interbed at a depth of $73 \mathrm{~m}$. Vertical fractures were observed in all cores and in every basalt flow. These fractures ranged in width from less than $1 \mathrm{~mm}$ to greater than $10 \mathrm{~mm}$. Some fractures were filled, some were lined, and some were totally devoid of sedimentary material.

Surficial sedimentary material was collected from several locations at the RWMC to determine the layer's lithologic and geochemical characteristics. The dominant particle size observed was $0.004 \mathrm{~mm}$ (clay size) with a dominant mineralogy of layered silicates (clay minerals). Mixed-layer clays and smectites accounted for as much as 64 percent of the clay minerals and as much as 41 percent of the bulk mineralogy of the sedimentary samples. This material had the highest cation exchange capacity. Carbonate content ranged from 36 percent in samples collected beneath the Early waste Retrieval (EWR) pit and as much as 62.9 percent in a massive caliche zone.

The interflow sedimentary bed at a depth of $9 \mathrm{~m}$ thins progressively to the south and east. It is overlain by a single basalt flow which contains fractures showing evidence of sequential sedimentary infilling. This sedimentary interbed consists of as much as $1.9 \mathrm{~m}$ of reddish-brown silty clay. Evidence of paleosol development is present. The reddish coloration of iron oxide was caused by hot volcanic flows that acted on iron-rich minerals as indicated by the absence of red coloration in fracture filling material below the interbed at a depth of $9 \mathrm{~m}$.

The interbed at a depth of $34 \mathrm{~m}$, with notable exceptions, is thin or absent; it is capped by an organic-rich (?) paleosol which contains calichecoated basalt pebbles, indicating significant exposure under a range of climatic conditions. Where the interbed at a depth of $34 \mathrm{~m}$ is absent, a basalt flow contact with secondary calcium carbonate (caliche) in vesicles and fractures is observed; this indicates the exposure of that surface for a geologically significant period of time. Clay-lined, sediment-filled fractures were observed down to the top of the interbed at a depth of $73 \mathrm{~m}$, indicating significant vertical migration of clay-size particles. 
The sedimentary interbed at a depth of $73 \mathrm{~m}$ is as much as $9.5-\mathrm{m}$ thick and exhibits iron-oxyhydroxide coloration throughout. The areal persistence and relatively equal altitude of the surface of the top of this interbed indicates that it is continuous under a large area of the southwestern INEL.

Samples of sedimentary material from the interbeds encountered in well 76-3 were analyzed for mineralogic composition, and where possible, stable isotope content. Bulk mineralogic analysis indicates that quartz, plagioclase and layered silicate minerals compose in excess of 95 percent of the sample. An additional 31 analyses were done on the $1-\mathrm{mm}$ size fraction of the samples to determine the mineralogic composition of the clay mineral material. Illite or mixed layer illite/smectite (I/S) were identified as the dominant clay mineral phases in all samples. Illite content ranged from 9.9 to 100 percent; I/S content ranged from 0 to 75 percent. The smectite content of the mixed layer component ranges from less than 20 percent to 60 percent. The samples with the highest illite content were found in the upper meter of the interbeds at depths of $34-\mathrm{m}$ and $73-\mathrm{m}$ and probably are related to baking by the overlying lava flows.

Precipitation studies indicate that the major influence on the groundwater hydrology of the Snake River Plain aquifer is recharge introduced by underflow from tributary stream valleys, and from infiltration of snowmelt into and percolation through the unsaturated zone. The snowmelt waters are in chemical equilibrium with soluble atmospheric gases and are of a stable isotope composition expected for meteoric waters. Water from the Big Lost River is representative of water recharged to the Snake River Plain aquifer through the "diversion ponds" and need to be compared to perched water observed beneath the RWMC.

Gases from the unsaturated-zone were collected and analyzed to determine seasonal changes in chemical composition and isotopic content. Changes in both were observed not only with the seasonal growth period for vegetation but also with changes in barometric pressure. The stableisotopic content of carbon dioxide in soil was observed to vary seasonally from approximately atmospheric values $(-7$ to $-10 \% / 00)$ during the nongrowing season to values representative of plant root respiration and/or 
microbial decomposition (-12 to $-20 \% / 00)$ during periods of higher temperature. Similar seasonal variations of higher magnitude were reported in other areas in a more temperate climate.

Perched-water bodies were encountered in numerous coreholes above the interbeds at depths of 9,34 and 73 meters. Perched-water samples collected were analyzed for $D$ and ${ }^{18} 0$ to determine the source of the perched water. An anomalously 1 ight isotopic content ( $\delta \mathrm{D}$ of $-140 \% \%, \delta^{18} \mathrm{o}$ of $-18.4 \%$ ) suggest a water source at an altitude higher than the surface of the Snake River Plain. This supports the hypothesis that the perched water observed beneath the RWMC is introduced into the shallow unsaturated zone by infiltration of Big Lost River water through diversion ponds located to the west of the RWMC. This is further supported by the $D-{ }^{18} 0$ isotopic relation, which indicates that the Snake River Plain aquifer ground water was significantly influenced by evaporation (slope of $\delta D-\delta 18$ relation is about 5), whereas the perched water approximates normal meteoric water (slope of $\delta D-\delta^{18} 0$ relation is about 8 ), indicating rapid recharge of large volumes of water.

Chemical analysis of these water samples indicate that they were in equilibrium with mineral phases of a higher cation exchange capacity, many of which are identified in the sedimentary material. The samples also were in equilibrium with the $\mathrm{P}_{\mathrm{CO}_{2}}$ observed in gas samples collected from the shallow unsaturated zone (average $\log \mathrm{P}_{\mathrm{CO}_{2}}$ of -3.14).

Results of oxygen isotope analysis of clay mineral samples ranged from +3.38 to $+18.11 \%$, with the bulk of the values falling within the range $(+8$ to $+12 \%$ expected for authigenic clay minerals in Idaho and Montana soils. Three samples anomalously enriched in ${ }^{18} 0$ were observed. These samples approach the oxygen isotopic content $\left(\delta^{18} \mathrm{O}\right.$ of $+20 \%$ observed for authigenic silica.

Carbon and oxygen-isotopic analyses were done on numerous samples of carbonate from throughout the area of interest. Carbon-13 values ranged from -12.28 to $+2.51 \%$, whereas $\delta{ }^{18} 0$ ranged from +9.99 to $+18.81 \%$. 
The carbon and oxygen isotopic data indicate that major climate changes have occurred in the vicinity of the INEL since the emplacement of the last basalt flow under the RWMC about 200,000 years ago and the deposition of sedimentary material thereon.

\section{SELECTED REFERENCES}

Arkley, R.J., 1963, Calculation of carbonate and water movement in soil from climatic data: Soil Science, v. 76, p. 230-248.

Bagby, J.C., White, L.J., Barraclough, J.T., and Jensen, R.G., 1984, Groundwater site inventory data for selected wells on or near the Idaho National Engineering Laboratory, 1949 through 1982: U.S. Geological Survey Open-File Report 84-231, 353 p.

Barraclough, J.T., Lewis, B.D., and Jensen, R.G., 1981, Hydrologic conditions at the Idaho National Engineering Laboratory, Idaho, Emphasis: 1974-1978: U.S. Geological Survey Water-Resources Investigations Open-File Report 81-526, 116 p.

Barraclough, J.T., Robertson, J.B., and Janzer, V.J., 1976, Hydrology of the solid waste burial ground, as related to the potential migration of radionuclides, Idaho National Engineering Laboratory, with a section on Drilling and sample analyses, by L.G. Saindon: U.S. Geological Survey Open-File Report 76-471, IDO-22056, 183 p.

Barraclough, J.T., Teasdale, W.E., and Jensen, R.G., 1967, Hydrology of the National Reactor Testing Station, Idaho, 1965: U.S. Geological Survey Open-File Report, IDO-22047, 107 p.

Barraclough, J.T., Teasdale, W.E., Robertson, J.B., and Jensen, R.G., 1967, Hydrology of the National Reactor Testing Station, Idaho, 1966: U.S . Geological Survey Open-File Report IDO-22048, 95 p.

Beukenkamp, P.C., and Sevink, J., 1971, Paleosols in the volcanic region of the Velay (Central Massif, France), in Yaalon, D.H., ed., Paleopedology: New York, Halsted Press, p. 293-299.

Boen, H.L., and DeMarraiss, G.A., 1960, Surface and subsurface temperature variations and comparisons: Public Roads, v. 30, p. 283-284.

Burgus, W.H., and Maestas, S.E., 1976, The 1975 RWMC core drilling program, a further investigation of subsurface radioactivity at the Radioactive Waste Management Complex, Idaho National Engineering Laboratory: U.S. Energy Research and Development Administration, Office of Waste Management, Idaho Operations Office Publication, IDO-10065, $36 \mathrm{p}$.

Christiansen, R.L., and Blank, H.R., Jr., 1972, Volcanic stratigraphy of the Quaternary rhyolite plateau in Yellowstone National Park: U.S. Geological Survey Professional Paper 729-B, 18 p. 
Cooke, R.V., and Warren, Andrew, 1973, Geomorphology of Deserts: Berkeley, University of California Press, $374 \mathrm{p}$.

Craig, Harmon, 1961a, Isotopic variations in meteoric waters: Science, v. 133 , p. $1702-1703$.

-... 1961b, Standard for reporting concentrations of deuterium and oxygen18 in natural waters: Science, v. 133, p. 1833-1834.

Crone, A., 1975, Laboratory and field studies of mechanically infiltrated matrix clay in arid fluvial sediments: University of Colorado, Boulder, Unpublished $\mathrm{Ph} . \mathrm{D}$. thesis, $162 \mathrm{p}$.

Dansgaard, W., 1964, Stable isotope in precipitation: Tellus, v. 16, p. $436-468$.

Deines, Peter, Langmuir, Donald, and Harmon, R.S., 1974, Stable carbon isotope ratios and the existence of a gas phase in the evolution of carbonate ground waters: Geochimica et Cosmochima Acta, v. 38, p. $1147-1164$.

Dort, Wakefield, Jr., and Miller, Susanne, 1977, Archaeological geology at Birch Creek Valley and the eastern Snake River Plain, Idaho: Geological Society of America, Division of Archaeological Geology Publication, $92 \mathrm{p}$.

Eber1, Dennis and Hower, John, 1976, Kinetics of il1ite formation: Geological Society of America Bulletin, v. 87, p. 1326-1330.

Epstein, S., Buchsbaum, R., Lowenstam, H.A., and Urey, H.C., 1953, Revised carbonate-water temperature scale: Geological Society of America Bulletin, v. 62, p. 417-426.

Friedman, Irving, and O'Neil, J.R., 1977, Compilation of stable isotope fractionation factors of geochemical interest: U.S. Geological Survey Professional Paper 440-KK, $109 \mathrm{p}$.

Friedman, Irving, Redfield, A.C., Schoen, Beatrice, and Harris, Joseph, 1964, The variation in deuterium content of natural waters in the hydrologic cycle: Review of Geophysics, v. 2, p. 177-224.

Goldich, S.S., 1938, A study in rock-weathering: Journal of Geology, v. 46, p. 17 .

Hait, M.H., Jr., and Scott, W.E., 1978, Holocene faulting, Lost River Range, Idaho: Geological Society of America, Abstracts with Programs, v. 10, p. 217 .

Helfferich, Friedrick, 1962, Ion Exchange: New York, McGraw-Hil1, 624 p.

Hower, John, Eslinger, E.V., Hower, M.E., and Perry, E.A., 1976, Mechanisin of burial metamorphism of argillaceous sediment: 1. Mineralogical and chemical evidence: Geological Society of America Bulletin, v. 87, p. $725-737$. 
Humphery, T.G., Tingey, F.H., 1978, The subsurface migration of radionuclides at the Radioactive Waste Management Complex, 1976-1977: U.S. Department of Energy, Idaho Operations Office Publication, TREE $1171,98 \mathrm{p}$.

Jenny, Hans and Leonard, C.D., 1934, Functional relationships between soil properties and rainfall: Soil Science, v. 38, p. 363-381

Junge, C.F., and Werby, R.T., 1958, The concentration of chloride, sodium, potassium, calcium, and sulfate in rain water over the United States: Journal of Meteorology, v. 15, p. 417-425.

Keeling, C.D., 1961, The concentration and isotopic abundances of atmospheric carbon dioxide in rural and marine air: Geochemica et Cosmochima Acta, v. 24, p. 277-298.

Kuntz, M.A., 1977a, Rift zones of the Snake River Plain, Idaho as extensions of basin-range and older structures: Geological Society of America, Abstracts with Programs, v. 9, p. 1061-1062.

Kuntz, M.A., 1977b, Structural and volcanic characteristics of the eastern Snake River Plain, Idaho: NASA Technical Memorandum 78, 436, p. 1-2.

Kuntz, M.A., 1978a, Geology of the Arco-Big Southern Butte area, eastern Snake River Plain, and volcanic hazards to the Radioactive Waste Management Complex, and other waste storage and reactor facilities at the Idaho National Engineering Laboratory, Idaho, with a section on statistical treatment of the age of lava flows, by J.O. Kork: U.S. Geological Survey Open-File Report 78-691, 70 p.

Kuntz, M.A., 1978b, Geologic map of the Arco-Big Southern Butte area, Butte, Blaine, and Bingham counties, Idaho: U.S. Geological Survey Open-File Report, 78-302, 1 sheet.

Kuntz, M.A., Dalrymple, G.G., Champion, D.E., and Doherty, D.J., 1980, Petrography, age, and paleomagnetism of volcanic rocks at the Radioactive Waste Management Complex, Idaho National Engineering Laboratory, Idaho, with an evaluation of potential volcanic hazards: U.S. Geological Survey Open-File Report, 80-388, 63 p.

Lawrence, J.R., 1970, ${ }^{18} \mathrm{O} /{ }^{16} \mathrm{O}$ and $\mathrm{D} / \mathrm{H}$ ratios of soils, weathering zones and clay deposits: California Institute of Technology, Pasadena, unpublished $\mathrm{PhD}$. thesis, $263 \mathrm{p}$.

Lawrence, J.R., and Taylor, H.P., Jr, 1971, Deuterium and oxygen-18 correlation: Clay minerals and hydroxides in Quaternary soils compared with meteoric waters: Geochimica et Cosmochima Acta, v. 35, p. 9831003 .

Lewis, B.D., and Goldstein, F.G., 1982, Evaluation of a predictive groundwater solute-transport model at the Idaho National Engineering Laboratory, Idaho: U.S. Geological Survey Water Resources Investigation $82-25,71 \mathrm{p}$. 
Lewis, B.D., and Jensen, R.G., 1985, Hydrologic conditions at the Idaho National Engineering Laboratory, Idaho: 1979-1981 update: U.S. Geological Survey Hydrologic Investigations Atlas HA-674, 2 sheets.

Mabey, D.R., Peterson, D.L., and Williams, Carol, 1974, Preliminary gravity map of southern Idaho: U.S. Geological Survey Open-File Report 74-78, 1 sheet.

McCrea, J.M., 1950, The isotopic chemistry of carbonates and a paliotemperature scale: Journal of Chemical Physics, v. 18, p. 849-857.

Mundorff, J.J., Crosthwaite, E.G., and Kilburn, Chabot, 1964, Ground water for irrigation in the Snake River Basin in Idaho: U.S. Geological Survey Water Supply Paper 1654, 224 p.

Nace, R.L, Deutsch, Morris, and Voegeli, P.T., 1972, Physical environment of the National Reactor Testing Station, Idaho, A Summary: U.S. Geological Survey Professional Paper 725-A, 38 p.

Nace, R.L., Veogeli, P.T., Jones, J.R., and Deutsch, Morris, 1975, Generalized geologic framework of the National Reactor Testing Station, Idaho: U.S. Geological Survey Professional Paper 725-B, 49 p.

Olmsted, F.H., 1962, Chemical and physical character of ground water in the National Reactor Testing Station, Idaho: U.S. Atomic Energy Commission, Idaho Operations office Publication, IDO-22043-USGS, 142 p.

O'Neil, J.R., and Kharaka, Y.K., 1976, Hydrogen and oxygen isotope exchange reactions between clay minerals and water: Geochimica et Cosmochima Acta, v. 40, p. 241-246.

O'Neil, J.R., and Taylor, H.P., Jr., 1969, Oxygen isotope equilibrium between muscovite and water: Journal of Geophysical Research, v. 74 , p. $6012-6022$.

Pearson, F.J., Jr, and Fisher, D.W., 1971, Chemical composition of atmospheric precipitation in the northeastern United States: U.S. Geological Survey Water-Supply Paper 1535-P, 23 p.

Perry, Ed, and Hower, John, 1970, Burial diagenesis in Gulf Coast pelitic sediments: Clays and Clay Minerals, v. 8, p. 165-177.

Plummer, L.N., Jones, B.F., and Truesde11, A.H., 1976, WATEQF-A Fortran IV Version of WATEQ, a computer program for calculating chemical equilibrium of natural waters: U.S. Geological Survey Water-Resources Investigations $76-13,15 \mathrm{p}$.

Reynolds, R.C., Jr, and Hower, John, 1970, The nature of interlayering in mixed-layer illite-montmorillonites: Clays and Clay Minerals, v. 18, p. $25-36$.

Rightmire, C.T., 1978a, Seasonal variation in $\mathrm{P}_{\mathrm{CO}_{2}}$ and ${ }^{13} \mathrm{C}$ content of soil atmosphere: Water Resources Research, v. 14, p. 691-692. 
-... 1978b, Changes in formation-gas composition and isotope content as indicators of unsaturated zone chemical reactions related to recharge events, in Proceedings of an International symposium on Isotope Hydrology: Vienna, International Atomic Energy Agency, Isotope Hydrology 1978 , v. II, p. 711-732.

-... 1984, Description and hydrogeologic implications of cored sedimentary material from the 1975 drilling program at the Radioactive Waste Management Complex, Idaho: U.S. Geological Survey Water-Resources Investigations Report 84-4071, 33p.

Rightmire, C.T., and Hanshaw, B.B., 1973, Relationship between the carbon isotope composition of soil $\mathrm{CO}_{2}$ and dissolved carbonated species in ground water: Water Resources Research, v. 9, p. 958-967.

Rightmire, C.T., and Lewis, B.D., 1987, Geologic data collected and analytical procedures used during a geochemical investigation of the unsaturated zone, Radioactive Waste Management Complex, Idaho National Engineering Laboratory, Idaho: U.S. Geological Survey Open-File Report $87-246,83 \mathrm{p}$.

Robertson, J.B., Schoen, Robert, and Barraclough, J.T., 1974, The influence of liquid waste disposal on the geochemistry of water at the National Reactor Testing Station, Idaho, 1952-1970: U.S. Geological Survey Open-File Report IDO-22053, 231 p.

Savin, S.M., and Epstein, Samue1, 1970, The oxygen and hydrogen isotope geochemistry of clay minerals: Geochimica et Cosmochima Acta, V. 34 , p. $25-42$.

Schultz, L.G., 1964, Quantitative interpretation of mineralogic composition from X-ray and chemical data for the Pierre Shale: U.S. Geological Survey Professional Paper 391-C, 31 p.

Sheppard, S.M.F., Nielsen, R.L., and Taylor, H.P., Jr., 1969, Oxygen and hydrogen isotope ratios of clay minerals for porphyry copper deposits: Economic Geology, v. 64, p. 755-777.

Stout, M.Z., and Nicholls, J., 1977, Mineralogy and petrology of Quaternary lavas from the Snake River Plain, Idaho: Canadian Journal of Earth Sciences, v. 14, p. 2140-2156.

Valastro, S., Jr., Davis, E.M., and Varela, A.G., 1972, University of Texas at Austin Radio carbon Dates IX: Radiocarbon, v. 14, p. 468-470.

Walker, E.H., 1964, Subsurface geology of the National Reactor Testing Station, Idaho: U.S. Geological Survey Bulletin 1133-E, 22 p.

Walker, T.R., Waugh, Brian, and Crone, A.J., 1978, Diagenesis in first-cycle desert alluvium of Cenozoic age, southwestern United states and northwestern Mexico: Geological Society of America Bulletin, v. 89 , p. $19-32$. 
Weeks, E.P., 1978, Field determinations of vertical permeability to air in the unsaturated zone: U.S. Geological Survey Professional Paper 1051, $41 \mathrm{p}$.

White, D.E., Hem, J.D., and Waring, G.A., 1963, Data of Geochemistry, Sixth Edition, Chapter F. Chemical composition of subsurface waters: U.S. Geological Survey Professional Paper 440-F, 67 p. 